\title{
EESTI LÄHIAJA UURIMINE 21. SAJANDIL
}

\author{
Toomas HIIO
}

\begin{abstract}
Eesti Sõjamuuseum - Kindral Laidoneri Muuseum, Mõisa tee 1, Viimsi, 74001; Eesti Mälu Instituut, Tõnismägi 8, Tallinn, 10119, Eesti, toomas.hiio@esm.ee

Artikkel vaatleb 21. sajandil peamiselt Eestis ja eesti ajaloolaste poolt 20. sajandi Eesti ajaloost kirjutatud üldkäsitlusi, monograafiaid, artikleid ja dokumendikogumikke, aga ka 20. sajandi ajaloo uurimiseks asutatud iseseisvate uurimisrühmade tegevust. Ülevaade on liigendatud kronoloogilis-temaatiliselt: 1905. aasta revolutsioon ja Esimene maailmasõda, riigiloomine ja Vabadussõda 1918-1920, sõdadevaheline Eesti Vabariik, omariikluse kaotamine ja Teine maailmasõda 1939-1945, Nõukogude aeg 1944-1991 ning iseseisvuse taastamine ja 20. sajandi lõpp.
\end{abstract}

Ajalooteadus, nagu iga teinegi teadus, on rahvusvaheline isegi siis, kui konkreetse uurimuse objekt on ajas ja ruumis piiratud. Lähtudes objektist - Eesti ajaloost - ei saa Eesti pinnal tegutsenud ja tegutsevate uurijate kõrval tähelepanuta jätta teisi, kes mujal maailmas uurisid või uurivad Eesti ajalugu. Kotkavaate võimalikkusest ja võimalustest teadlik olles eritletakse viimase veerandsajandi ajalookirjutust järgnevalt ikkagi Eesti mättal ja mättalt, seda artiklimahu seatud piiride pärast. Eesti ajaloost kirjutatakse ja Eesti ajaloolased kirjutavad ka raamatutes ja artiklites, mis avaldatakse väljaspool Eestit. Avatud ja ajavaheta akadeemilises maailmas mõjutavad sealsed siinseid kas trotsima või hoopis matkima ning siinsed sealseid omakorda sedavõrd, kuivõrd on esimeste eestikeelsed tekstid teistele üle keelebarjääri üldse kättesaadavad. Lõpuks on avatud maailmas neidki, kes suudavad olla korraga nii siin kui seal.

Mida õieti on historiograafias uurida? Esiteks, leida üles, mis on üldse tehtud, ja koostada kataloog, kartoteek või kaust. Teiseks seda, kuidas ajalookirjutus ja ajalooks saanud olevik teineteist vastastikku on mõjutanud ja mõjutavad. Siin on mälestustel suur roll. Nende kõrval korraldab teadmiste levikut minevikust ka turg ajalugu „müüb“. Järgnevast jäetakse välja populaarsed ajalootooted, mis on valminud kiirtööna, kehvasti toimetatud raamatukestena, ning jutustavad ümber mälestusi ja koostajatele jõukohaseid uurimusi. Neid on eriti palju just lähimineviku, 20. sajandi ajaloo kohta. Ajaloo kulgemise järskude pöörete tõttu on ajalookirjutust ja 
tema teemade kataloogi alati mõjutanud riigi ja rahva poliitilised valikud ning nendest tulenev ajaloo uurimise vajadus, Eesti näitel: riikliku iseseisvuse taastamisele järgnenud uurimistöö õigusliku järjepidevuse põhistamiseks ning omandireformi ja kodakondsusseaduse rakendamisest tulenevad arhiiviuuringud. Suur mõju lähiajaloo uurimisteemade valikule on olnud ajaloo kasutamisel ja väärkasutamisel riikidevahelises suhtlemises ja propagandavastasseisudes, aga ka arhiivide avamisel 1990. aastate alguses, kiirel digiteerimisel, akadeemiliste mõõdikute sisseseadmisel ja paljul muul. Lõpuks küsitakse, kuhu on viimasel veerandsajandil jõutud ja mis on jäänud tegemata.

Vaatluse alt on teadlikult kõrvale jäetud ajaloo eridistsipliinide - arheoloogia, etnoloogia ja kunstiajaloo - saavutused. Ajalugu on interdistsiplinaarne nagu iga teine teadus ja tema piirid teiste teadusvaldkondadega on pigem lainetele joonitud kui kivisse raiutud. Seetõttu on artiklis tehtud valik - mitte väga range, aga siiski ja püütakse käsitleda valdavalt tekste ja uurimusi, mille on kirjutanud õpetlased, kes on oma väitekirjad kaitsnud ajaloo alal. Selleski vallas on eelistatud uuemaid tekste vanematele, sest uurimistöö metodoloogiast tulenevalt sisaldavad uuemad käsitlused enamasti varasemate teadmist ja põhinevad nendel. Artikli fookus on poliitilisel ja sõjaajalool, põgusamalt on kaetud sotsiaal- ja majandusajalugu, vaeslapse ossa on jäänud kultuuriajalugu.

\section{LÄHIAJA UURIMISE INSTITUTSIONAALNE KORRALDUS}

1990. aastate lõpuni tehti põhiosa Eesti ajaloo uurimisest kahes suures keskuses: Tartu Ülikooli 1991. aastal asutatud filosoofiateaduskonna endisest ajalooteaduskonnast lähtunud allüksustes, mida on korduvalt ümber korraldatud, ning endises Eesti Teaduste Akadeemia Ajaloo Instituudis, mis 2005. aastaks ühendati Tallinna Ülikooliga. 1990. aastatel muutusid silmapaistvaiks uurimiskeskusteks toonased keskarhiivid, Eesti Ajalooarhiiv Tartus ja Riigiarhiiv Tallinnas - 20. sajandi ajalukku puutuvas rohkem viimane -, mis koos enamiku väiksemate arhiividega on nüüdseks ühendatud Rahvusarhiiviks. 21. sajandi alguses hoogustus teaduslik uurimistöö ka Eesti suuremates muuseumides, sest see sõnastati muuseumide üheks tegevusvaldkonnaks. ${ }^{1}$

1990. aastate teisel poolel pandi alus kolmele uurimiskeskusele, mille ülesandeks oli 20. sajandi, täpsemini ühe osa 20. sajandi Eesti ajaloo uurimine. 1996. aasta novembris alustas Eesti Riigiarhiivi juures tööd Nõukogude Aja Uurimiskeskus (SKeskus) eesmärgiga ,uurida lähiajalugu ja mitte lasta sel vajuda unustusehõlma“. ${ }^{2}$ 1999. aastal reorganiseeriti see mittetulundusühinguks, ambitsioonika eesmärgiga uurida Eesti ajalugu aastatel 1939-1956 ning avaldada kümneköiteline koguteos

1 Eest ajalooteaduse institutsionaalsest korraldusest lähemalt vt Marek Tamme artiklit siinsamas ajakirjanumbris.

2 Rajaotsingud: 14. detsembril 1996 Tartus ja 18. märtsil 1987 Tallinnas toimunud lähiajaloo seminaride materjalid. Kistler-Ritso Eesti Sihtasutus, Nõukogude Aja Uurimiskeskus (S-Keskus), Eesti Riigiarhiiv, Tallinn, 1999, 3. 
„Sõja ja rahu vahel“. Praeguseks on kaante vahele jõudnud kaks köidet, ${ }^{3}$ kolm köidet on toimetamise ja avaldamise ootel.

1998. aasta sügisel registreeriti Eestis Kistler-Ritso Eesti Sihtasutus, mille eesmärk oli rajada Tallinna okupatsioonide muuseum. Sihtasutus põhines 1944. aastal Eestist põgenenud Olga Kistler-Ritso ja tema šveitslasest abikaasa Walter Kistleri eraannetusel. Muuseumile pandi nurgakivi 2002. aastal ja see avati 2003. aasta suvel (nüüdseks on muuseum reorganiseeritud okupatsioonide ja vabaduse muuseumiks Vabamu). Lisaks muuseumi rajamisele edendas sihtasutus Eesti lähiajaloo teaduslikku uurimistööd: avaldati mitu teatmiku tüüpi uurimust ja kogumikku (vt edaspidi). ${ }^{4}$

1998. aasta mais kohtusid Riias Leedu, Läti ja Eesti president. Kohtumise päevakorras oli muu hulgas ka lähiajaloo uurimise edendamine. Selleks ajaks olid Balti riikide parlamendid otsustanud taotleda oma riikide vastuvõtmist Euroopa Liitu ja NATO-sse. Paljude tingimuste kõrval, mis selleks tuli täita, oli ka „toimetulek oma minevikuga“" (sks Vergangenheitsbewältigung). Eeskätt peeti silmas selguse loomist Teise maailmasõja, eriti Saksa okupatsiooni ajal toimunus ning Leedu, Läti ja Eesti kodanike ja elanike osalemises holokaustis, samuti teistes Saksa okupatsiooni ajal Balti riikides, aga ka väljaspool toime pandud inimsusvastastes kuritegudes. Riia kohtumisel otsustati, et iga riik asutab oma rahvusvahelise komisjoni Teise maailmasõja ajal ja pärast seda toimunu uurimiseks. Presidendid ei saanud aga lähtuda ainult Euroopa Liidu ja NATO-ga liitumisläbirääkimiste huvist Saksa okupatsiooni asjad klaariks teha, sest Balti riikide kodanikkond, nende seas tugeva survegrupina inimesed, kes olid Gulagi laagritest ja küüditamistest eluga pääsenud, samuti Balti pagulased, ja mõlema inimrühma järeltulijad ootasid õigustatult hoopis kommunismikuritegude senisest usinamat uurimist, peljates, et palav soov liituda EL-i ja NATOga pühib mälestuse nende kannatustest vaiba alla. Leedulased asutasid rahvusvahelise komisjoni Leedus natsi- ja sovetliku okupatsioonirežiimi kuritegude hindamiseks ${ }^{5}$ ning lätlased Läti ajaloolaste komisjoni. ${ }^{6}$ Lennart Meri kutsus ellu Inimsusevastaste Kuritegude Eesti Rahvusvahelise Komisjoni. Ta soovis komisjoni tegevuse tulemusi näha enne oma ametiaja lõppu. See oli üks põhjusi, miks ei algatatud koostööd ülikoolide ja Ajaloo Instituudiga, vaid moodustati eraldi uurimisrühm noorematest eesti ajaloolastest. Uurimisrühma raportid tõlgiti inglise keelde, mille

\footnotetext{
3 Sõja ja rahu vahel I: Eesti julgeolekupoliitika 1940. aastani. Peatoim E. Tarvel, toim T. Tannberg. S-Keskus, Tallinn 2004; Sõja ja rahu vahel II: Esimene punane aasta: Okupeeritud Eesti julgeolekupoliitiline olukord sõja alguseni. Peatoim E. Tarvel, toim M. Maripuu. S-Keskus, Tallinn, 2010.

4 Kõrgemad võimu vahendajad ENSV-s: Eestimaa Kommunistliku Partei Keskkomitee sekretärid 1940-1990: Teatmik. Koost O. Liivik, toim E. Tarvel; Eestimaa Kommunistliku Partei Keskkomitee organisatsiooniline struktuur 1940-1991. Koost ja toim E. Tarvel; Eestimaa Kommunistliku Partei kohalikud organisatsioonid 1940-1991. Koost ja toim E. Tarvel. Kõik Kistler-Ritso Eesti Sihtasutus, Tallinn, vastavalt 2000, 2002, 2005. Klesment, M., Nugin, R., Tarvel, E. Partei-algorganisatsioon: Kommunistliku poliitika esmane elluviija okupeeritud Eestis 1940-1991. Toim E. Tarvel. KistlerRitso Eesti Sihtasutus, Tallinn, 2009.

5 Tarptautine komisija nacių ir sovietinio okupacinių režimų nusikaltimams Lietuvoje ịvertinti (ingl: The International Commission for the Evaluation of the Crimes of the Nazi and Soviet Occupation Regimes in Lithuania), vt https://www.komisija.lt/en/about-commission/ (30.06.2020).

${ }^{6}$ Latvijas Vēsturnieku komisija, Commission of the Historians of Latvia - koduleht puudub, vt http://lpra.vip.lv/komisija.htm (30.06.2020).
} 
põhjal komisjon koostas oma istungitel järeldused-kokkuvõtted. Siiski jõuti enne president Meri ametiaja lõppu 2001. aastal valmis ainult raport Saksa okupatsiooni kohta. Esimese Nõukogude okupatsiooni ja sõjajärgse aja raport valmisid hiljem. Kõik kolm avaldati inglise keeles eraldi raamatutena 2006. ja 2009. aastal. ${ }^{7}$ Komisjon lõpetas tegevuse 2008/2009. aasta vahetusel. ${ }^{8}$ Suurema osa selleks ajaks juba üsna vilunud uurimisrühmast võttis üle president Toomas Hendrik Ilvese 2008. aastal asutatud Mälu Instituut. Leedu, Läti ja Eesti okupatsioonideaegse ajaloo uurimise tõhustamisel ja tutvustamisel rahvusvahelises avalikkuses, eriti välispoliitikaringkonnis, oli ja on komisjonidel märgatav roll.

21. sajandi alguseks olid juba kümmekond aastat tegutsenud veel kaks uurimiskeskust. Nõukogude massirepressioonide ohvrite saatuse väljaselgitamisega hakkas rahvaalgatuse korras tegelema Eesti Õigusvastaselt Represseeritute Liidu Memento (asutati 1949. aasta küüditamise 40. aastapäeval 1989. aasta märtsis) teabe- ja ajalootoimkond, hilisem Eesti Represseeritute Registri Büroo (ERRB). 1991. aastal toodi NSV Liidust Eestisse mitukümmend tuhat Eestis poliitilistel põhjustel süüdi mõistetud ja hukatud, Gulagi vangilaagritesse saadetud või küüditatud inimeste toimikut, mis 1993. aastal riiklikule arhiivisüsteemile üle anti. Need materjalid on repressiooniohvrite saatuse väljaselgitamise tähtsaim allikabaas. Eesti ühiskonna väiksus, aga ka uurijate juurdepääs Nõukogude julgeolekuasutuste Stalini-aegsete poliitiliste repressioonide toimikutele võimaldas Eesti uurijatel juba 1990. aastate alguses alustada ohvrite nimelist väljaselgitamist, et koostada nende täielik nimekiri, sel ajal kui teistes riikides vaieldi enamasti veel ohvrite koguarvu üle ja kirjeldati hukkamiste, vangilaagrite ja küüdituse koledusi. Alates 1996. aastast ilmunud poliitiliste repressioonide ohvrite nimekirjad, mituteist raamatut, on täistekstina veebis. ${ }^{9}$

2005. aastal lõpetas „Valge raamatu“ avaldamisega tegevuse Okupatsioonide Repressiivpoliitika Uurimise Riiklik Komisjon, mille Eesti Vabariigi Ülemnõukogu oli moodustanud 26. märtsil 1992 „Nõukogude ja Saksa okupatsiooni aastatel Eesti Vabariigi territooriumil, samuti tema kodanike suhtes teiste riikide territooriumidel kohaldatud repressiivpoliitika analüüsimiseks, toimepandud genotsiidikuritegude väljaselgitamiseks ning üldise hinnangu väljatöötamiseks“. Kuni 1996. aastani oli komisjoni esimees Jaan Kross, seejärel Vello Salo. ${ }^{10}$ Komisjoni töö kõrvaltulemu-

7 Estonia 1940-1945: Reports of the Estonian International Commission for the Investigation of Crimes Against Humanity. Ed. by T. Hiio, M. Maripuu, I. Paavle. Estonian Foundation for the Investigation of Crimes Against Humanity, Tallinn, 2006; Estonia since 1944: Reports of the Estonian International Commission for the Investigation of Crimes Against Humanity. Ed. by T. Hiio, M. Maripuu, I. Paavle. Estonian Foundation for the Investigation of Crimes Against Humanity, Tallinn, 2009.

8 Komisjoni veebikülge hoiab Eesti Mälu Instituut, vt http://www.mnemosyne.ee/hc.ee/ (30.06.2020).

9 Köited 1-14, vt Eesti Memento Liit, Trükised, Memento raamatud, https://www.memento.ee/trukised/memento-raamatud/ (30.06.2020). Nendel raamatutel põhinev paranduste ja täiendustega veebiandmebaas on Eesti kommunismiohvrid 1940-1991, https://www.memoriaal.ee/ (30.06.2020), mida haldab Eesti Mälu Instituut.

${ }^{10}$ Valge raamat: Eesti rahva kaotustest okupatsioonide läbi 1940-1991. Toim Ü. Ennuste, E. Parmasto, E. Tarvel, P. Varju. Okupatsioonide Repressiivpoliitika Uurimise Riiklik Komison, Eesti Entsüklopeediakirjastus, Tallinn, 2005. (Ilmus ka inglise keeles.) 
seks oli paarkümmend raamatut (nn ORURK-sari) okupatsioonitagajärgede kohta eri eluvaldkondades. ${ }^{11}$ Selles sarjas ilmus ka Memento raamatute mudelit järgiv Saksa okupatsiooni ajal hukatute ja vanglas surnute nimekiri koos lühibiograafiatega, aga ka 1941. aastal küüditatud Eesti juutide nimekiri. ${ }^{12}$ Komisjoni publitseerimistööd jätkab Sihtasutus Valge Raamat. ${ }^{13}$

Memento ERRB ja ORURK-i töö on toonud lähiajaloo tuhandete Eesti inimesteni nende oma perekonna loo kaudu. 1990. aastad oli aeg, kui koos esimeste võimsamate personaalarvutite tavakasutajani jõudmisega hakati looma isikuandmekogusid ja kasutama neid nii teaduslikus uurimistöös kui ka asjaarmastajate poolt. 20. sajandil elanud inimeste andmete koondamist ja töötlemist on piiranud isikuandmete töötlemist reguleeriv seadusandlus, siiski on möödunud sajandil elanud ja tegutsenud Eesti inimeste kohta veebis vabakasutuses mitu andmekogu. ${ }^{14}$

Lähiajaloo uurimise, selle kasutamise ja ärakasutamise ning riiklik-rahvusliku identiteedi taaselustamise või loomise teema komplekssus on pälvinud Eesti ja välismaa ühiskonnateadlaste tähelepanu. ${ }^{15}$ Mitte alati pole ajaloosündmuste, ühiskonna-, ajaloo- ja poliitikateooriate ning külma sõja ajast päritud mustvalgete vastanduste sasipuntra lahtiharutamine olnud autoritele jõukohane, eriti kui kompromiss paralleelide tõmbamise ja avarama üldistuse loomise ning faktide ja asjaolude vahel on tehtud kahe esimese kasuks.

\section{ÜLDKÄSITLUSED EESTI JA EESTI VABARIIGI AJALOOST}

Eestikeelse ülikooli 80. aastapäeval 1. detsembril 1999 algatasid Eesti ajaloolased professor Sulev Vahtre juhtimisel ning president Lennart Meri ja peaminister Mart Laari toetusel uue Eesti ajaloo üldkäsitluse koostamise, mis pidi jätkama 1930. aastatel Hans Kruusi ja Harri Moora poolt algatatud sariväljannet. ${ }^{16}$ Esimesena ilmuski

${ }^{11}$ Vt Okupatsioonide Repressiivpoliitika Uurimise Riiklik Komisjon, sari, 1-21, 1993-2004.

12 Eesti rahvastikukaotused II/1: Saksa okupatsioon 1941-1944: hukatud ja vangistuses hukkunud = Population losses in Estonia II/1: German occupation 1941-1944. Koost I. Paavle. (ORURK, 17.) Okupatsioonide Repressiivpoliitika Uurimise Riiklik Komisjon, Tartu, 2002; Salo, V. Population losses 1940-1941: Citizens of Jewish nationality. (ORURK, 18.) Estonian State Commission on Examination of the Policies of Repression, Tartu, 2002.

${ }^{13}$ Vt nt Haud, J., Raukas, A., Salo, V., Varju, P. Eesti okupatsioonikahjud ja inimkaotused. Valge Raamat, Tallinn, 2018.

${ }^{14}$ Onomastika: Eestlaste perekonnanimed, http://www.ra.ee/apps/onomastika/; Album Academicum Universitatis Tartuensis 1918-1944, http://www.ra.ee/apps/andmed/index.php/site/aaut; Eestlased Esimeses maailmasõjas, Rahvusarhiivi ühisloome algatus, http://www.ra.ee/ilmasoda/; Vabadussõda, Ühisloomealgatus, http://www.ra.ee/vabadussoda; Eesti ohvitserid 1918-1940, http://prosopos.esm.ee/index.aspx?type=1 (kõik 04.07.2020).

${ }^{15} \mathrm{Vt}$ nt Pettai, E.-C. Negotiating history for reconciliation: A comparative evaluation of Baltic presidential commissions. - Europe-Asia Studies, 2015, 67, 7, 1079-1101; Wulf, M. Shadowlands: Memory and history in post-Soviet Estonia. Berghahn Books, New York, Oxford, 2016.

${ }^{16}$ Vt Vabariigi President arutas Eesti Ajaloo avaldamisega seotut. 01.12.1999. Eesti Vabariigi Presidendi kantselei ametlikud teated 1992-2001, https://vp1992-2001.president.ee/est/ateated/AmetlikTeade.asp?ID=1789 (04.07.2020). 
neljas köide 18. sajandi kohta, seejärel aga „lühikese 20. sajandi“17 köide. Oma struktuurilt ja käsitluslaadilt on viimane pigem konservatiivne - oligi ta ju mõeldud järjena 1930. aastatel alustatud sarjale - ning põhineb selleks ajaks avaldatud tekstidel. Põhjalikumat uurimust köite jaoks ei tehtud, raamat peegeldab sajandivahetuse üldist uurimisseisu.

Järgmine Eesti ajaloo käsitlus ilmus teeneka Soome professori Seppo Zetterbergi sulest - soome keelest tõlgituna-täiendatuna ja eesti ajaloolaste toimetatuna. Zetterbergi üldkäsitlus on eelnimetatust värskem, autor on kasutanud ka 21. sajandi esimese kümnendi uurimusi. ${ }^{18}$ Seni viimasena avaldas professor Enn Tarvel 2018. aastal raamatu „Eesti rahva lugu“, mis on rohkem kui pool sajandit Eesti ajaloo eri perioode uurinud autori vaade Eesti ajaloole alates algusest kuni tänapäevani. ${ }^{19}$ Raamat kutsus esile märkimisväärse avaliku poleemika, mis jäi küll Eesti riigi 100. aastapäeva tähistamise rituaalide varju. Siia ritta kuulub ka sari „Eesti ... 100 aastat“", milles aastatel 2018-2019 ilmus 43 raamatut kümnete eluvaldkondade, institutsioonide ja asutuste ajaloost nii ajaloolaste kui ka teiste valdkonna asjatundjate sulest. Ambitsioonika ettevõtmise kiire tootmistsükli tõttu - umbes üks raamat nädalas - on tase ebaühtlane. 2019. aasta lõpul valmis akadeemiline koguteos Tallinna ajaloost, mille kahes viimases köites on peatükid 20. sajandi ajaloost. Mõistagi pole Eesti pealinna ajalugu uuritav väljaspool Eesti ajalugu. Koguteos esindab 20. sajandi osas nüüdseks juba kinnistunud ajalookäsitust. ${ }^{20}$ Üldkäsitluste osas väärib nimetamist ka Toomas Karjahärma ja Väino Sirgu kolmeosaline monograafia Eesti haritlaskonna kujunemisloost. ${ }^{21}$

\section{UURIMUSED JA MONOGRAAFIAD 20. SAJANDI EESTI AJALOOST}

20. sajandi Eesti ajaloo uurimise 21. sajandit ei saa alustada täpselt 2001. aasta 1. jaanuarist. Esimesed põhjalikumad käsitlused, mis olid loodud pärast arhiivide avamist, ilmusid 1990. aastate keskel. 1996. aastal avaldati peamiselt KGB ja teiste Nõukogude asutuste arhiivimaterjalide põhjal valminud Indrek Jürjo monograafia „Pagulus ja Nõukogude Eesti: Vaateid KGB, EKP ja VEKSA arhiividokumentide põhjal“. Raamat sünnitas poleemika julgeoleku- ja parteidokumentide usaldatavuse

\footnotetext{
${ }^{17}$ Eesti ajalugu VI: Vabadussõjast taasiseseisvumiseni. Peatoim S. Vahtre. Tegevtoim. A. Pajur, T. Tannberg. Õpetatud Eesti Selts, Ilmamaa, Tartu, 2005.

${ }^{18}$ Zetteberg, S. Eesti ajalugu. Tlk M. Berg jt. Toim A. Mäesalu, M. Laidre, T. Tannberg, A. Pajur. Tänapäev, Tallinn, 2009.

${ }^{19}$ Tarvel, E. Eesti rahva lugu. Varrak, Tallinn, 2018.

${ }^{20}$ Tallinna ajalugu III: 1710-1917. Koost T. Kala, L. Kõiv, O. Liivik, peatoim T. Kala, toim T. Tamla; Tallinna ajalugu IV: 1917-2019. Koost O. Liivik, peatoim T. Kala, toim T. Tamla. Mõlemad köited Tallinna Linnaarhiiv, Tallinn, 2019.

${ }^{21}$ Karjahärm, T., Sirk, V. Eesti haritlaskonna kujunemine ja ideed 1850-1917. Eesti Entsüklopeediakirjastus, Tallinn, 1997; Karjahärm, T., Sirk, V. Vaim ja võim: Eesti haritlaskond 1917-1940. Argo, Tallinn, 2001; Karjahärm, T., Sirk, V. Kohanemine ja vastupanu: Eesti haritlaskond 1940 1987. Argo, Tallinn, 2007.
} 
üle ajalooallikana ning pahameeltki, sest mitut paguluses või ka Eestis tuntud inimest kujutati senisest palju mitmepalgelisemalt. ${ }^{22}$ Jürjo professionaalsust näitab asjaolu, et raamat on väärtuse ja tsiteeritavuse säilitanud veerand sajandit hiljemgi. Samal ajal alustati parteiarhiivi jäänud Eesti NSV KGB osakondade aruannete tõlkimise ja publitseerimisega. ${ }^{23}$ (Suur osa KGB arhiivist oli Eesti iseseisvuse taastamise eel Venemaale viidud. ${ }^{24}$ )

1990. aastate teisel poolel jõudsid kaante vahele mitme varem ülikoolis või kõrgkoolides kommunistliku partei või NSV Liidu ajalugu õpetanud ajaloolase teosed, mille kirjutamiseks oli olnud juurdepääs parteiarhiivile ka Nõukogude ajal, kuid uurimistöö tulemuste avaldamist oli piiranud tsensuur samamoodi kui teisi ja tööd ennast oli raamistanud ,sügavalt juurdunud marksistlik-leninlik metodoloogia“ ${ }^{25}$ Lembit Raidi 1995. aasta monograafia uuris stalinistlikke repressioone Tartu ülikoolis. ${ }^{26}$ Toomas Karjahärmi raamat Eestist Venemaa koosseisus 19. sajandi keskpaigast kuni impeeriumi lõpuni ilmus 1998. aastal. ${ }^{27} 1999$. aastal ilmunud Olaf Kuuli raamat „Sotsialistid ja kommunistid Eestis 1917-1991“28 sisaldas peale nimetatute ülevaate ka teistest Eesti parteidest enne 1940. aastat. Mati Grafi järgmisel aastal avaldatud monograafia „Parteid Eesti Vabariigis 1918-1934“ pealkiri räägib enda eest ise. ${ }^{29}$

Toonastest noorema põlvkonna uurijatest kaitses Eero Medijainen 1997. aastal väitekirja Eesti välispoliitikast, ${ }^{30}$ 1999. aastal ilmus Ago Pajuri monograafia Eesti riigikaitsepoliitikast. ${ }^{31}$ Vahur Made monograafia oli esimene 20. sajandi Eesti ajalugu käsitlev töö Tartu Ülikooli ajalooväitekirjade sarjas. ${ }^{32}$ Nüüdseks on peale kasvanud uus 20. sajandi Eesti ajaloo uurijate põlvkond. Tartu Ülikooli ajaloo-doktoritööde

22 Jürjo, I. Pagulus ja Nõukogude Eesti: Vaateid KGB, EKP ja VEKSA arhiividokumentide põhjal. Umara, Tallinn 1996; 2. tr. Tammerraamat, Tallinn, 2014.

${ }^{23}$ Aruanne ENSV Ministrite Nõukogu juures asuva Riikliku Julgeoleku Komitee 2. vastuluureosakonna tööst ajavahemikul 1. IV 1954 - 1. IV 1955. Toim J. Ojamaa, J. Hion. (Ad fontes, 2.) Umara, Tallinn, 1997. Järgnevate aastate aruanded vt: Ad fontes 4, 6, 8. Umara, Tallinn, 1998, 1999, 2000 ning Ad fontes 10 ja 14. Eesti Rahvusarhiiv, Tallinn, 2002, 2005.

${ }^{24}$ Selle kohta vt: Эстонско-латышско-литовский совместный семинар „Документы КГБ в Балтийских странах“: Доклады. Филиал Государственного архива Эстонии. Акадеэмия трюкк, Таллинн, 1996, 18-23.

${ }^{25}$ Tsitaat - vt: Leninlik etapp eesti ajalooteaduses: Historiograafilisi artikleid. Koost ja toim E. Laul. Eesti Raamat, Tallinn, 1970, 47-48.

${ }^{26}$ Raid, L. Vaevatee: Tartu Ülikool kommunistlikus parteipoliitikas aastail 1940-1952. Tartu Ülikooli Kirjastus, Tartu, 1995.

${ }^{27}$ Karjahärm, T. Ida ja Lääne vahel: Eesti-Vene suhted 1850-1917. Eesti Entsüklopeediakirjastus, Tallinn, 1998.

${ }^{28}$ Kuuli, O. Sotsialistid ja kommunistid Eestis 1917-1991. O. Kuuli, Tallinn, 1999.

${ }^{29}$ Graf, M. Parteid Eesti Vabariigis 1918-1934: Koos eellooga 1905-1917 ja järellooga 1934-1940. Tallinna Pedagoogikaülikooli kirjastus, Tallinn, 2000.

${ }^{30}$ Medijainen, E. Eesti välisministeerium ja saatkonnad 1918-1940: Doktoriväitekiri. Tartu Ülikooli filosoofiateaduskond, 1997. Raamatuna: Medijainen, E. Saadiku saatus: Välisministeerium ja saatkonnad 1918-1940. Eesti Entsüklopeediakirjastus, Tallinn, 1997.

${ }^{31}$ Eesti riigikaitsepoliitika aastail 1918-1934. Koost A. Pajur. Eesti Ajalooarhiiv, Tartu, 1999.

${ }^{32}$ Made, V. Eesti ja Rahvasteliit. (Dissertationes historiae Universitatis Tartuensis, 3.) Tartu Ülikooli Kirjastus, Tartu, 1999. 
sarjas on aastatel 1992-2020 ilmunud 49 monograafiat, neist pooled 20. sajandi Eesti ajaloost. Lisanduvad teistes sarjades ilmunud tööd ja 1990. aastate alguse teadusmagistritööd. Tallinna Ülikool avaldab ajaloo-alased doktoritööd oma humanitaarteaduste dissertatsioonide sarjas, mille kümmekonnast ajalooalasest väitekirjast käsitlevad 20. sajandi Eesti ajalugu samuti umbes pooled. Mõni sisu poolest ajalooalane doktoritöö on kaitstud teistel erialadel. Mitu väitekirja 20. sajandi Eesti ajaloost on eesti ajaloolased kaitsnud välismaa ülikoolides..$^{33}$

Järgnev on liigendatud teemade kaupa, sest ainult sel viisil saab mahtuda ühe artikli raamidesse. Keskendun 20. sajandi suurematele teemadele, millega seoses annan ülevaate ülejäänustki. Nendeks teemadeks on kronoloogilises järjekorras mõneti meelevaldse valikuna: 1905. aasta revolutsioon ja Esimene maailmasõda, aastad 1918-1920 (riigiloomine ja Vabadussõda), Eesti Vabariik 1918/1920-1940, omariikluse kaotamine ja Teine maailmasõda (1939-1945), Nõukogude aeg (19441991) ja sõjajärgsed massirepressioonid ning iseseisvuse taastamine ja sajandi viimane aastakümme.

\section{AASTA REVOLUTSIOON JA ESIMENE MAAILMASÕDA}

1905. aasta revolutsioon oli ühelt poolt tähtis sündmus eesti rahvusluse ajaloos ja omariikluse eelloos, teiselt poolt aga vähemalt sama tähtis revolutsiooniajaloo komponent marksistlik-leninliku ühiskondlike formatsioonide ja revolutsiooniteoorias lõpetamata jäänud „kodanlik-demokraatlik revolutsioon“-, ilma milleta poleks 1917. aasta Vene revolutsioonid olnud võimalikud. 1905. aasta revolutsioon oli avaliku rahvusliku poliitika ja pahempoolse poliitika (sotsiaaldemokraatidest enamlasteni) sünniaeg. Revolutsiooni ajal tegutsesid aktiivselt nii hilisemad riigivanemad Konstantin Päts, Jaan Tõnisson, August Rei, Jaan Teemant ja Otto Strandman kui ka hilisemad Eesti enamlaste juhid Jaan Anvelt, Viktor Kingissepp ja Hans Pöögelmann. Taustal tegutses noor mässaja, salapärane Aleksander Kesküla, kelle Kaido Jaanson 21. sajandi esimesel kümnendil Eesti ajalukku kirjutas, ${ }^{34}$ järjena Suure Ajaloo kujundamisel kaasa löönud eestlaste lugudele, mis olid populaarsed sovetiaja viimaste kümnendite kirjandusteostes, mis leidsid oma ainese Eesti ajaloost.

Nõukogude ajal kaeti 1905. aasta revolutsiooni teema hulga ametlikku kontseptsiooni järgivate ja seda põlistavate tekstidega, mistõttu 1990. aastatel seda vaistlikult

\footnotetext{
${ }^{33}$ Näiteks doktoritööd: Ilmjärv, M. Silent submission: Formation of foreign policy of Estonia, Latvia and Lithuania - period from mid-1920-s to annexation in 1940. (Acta Universitatis Stockholmiensis. Studia Baltica Stockholmiensia.) Stockholm University Deptartment of History, Stockholm, 2004; Piirimäe, K. Estonia, the Baltic question and the „big three“ allies in World War Two. Cambridge University, 2010.

${ }^{34}$ Nt Jaanson, K. Sõbrad: Vähemlane Otto Sternbeck ja enamlane Aleksander Kesküla. - Tuna, 2007, 2, 28-41; Jaanson, K. Eestlane Aleksander Kesküla ja Berliin: avang (september 1914 - mai 1915) - Tuna, 2004, 1, 12-38; Jaanson, K. Aleksander Kesküla maailmanägemus. - Acta Historica Tallinnensia, 2002, 6, 108-124; Jaanson, K. Juan Linz ja eestlane Aleksander Kesküla. - Akadeemia, 2002, 2, 227-251; Jaanson, K. Eestlane Aleksander Kesküla ja Rahvuste Uniooni III konverents Lausanne'is 1916. aastal. - Akadeemia, 2000, 9, 1824-1862.
} 
isegi pisut peljati. Korraks meenutas revolutsioonisündmusi president Meri 2000. aastal Uue turu veretöö ohvreid mälestades, kui kutsus üles 1905. aasta revolutsiooni ajalugu omariikluse ajaloole tagasi võitma. ${ }^{35}$ Tõsisemalt hakati asjaga tegelema kümmekonna aasta pärast. Kirjastus Ilmamaa andis täiendatud, toimetatud ja kommenteeritud kujul välja Mihkel Aitsami (1877-1953) dokumentaalse käsikirja 1905. aasta sündmustest. Peatselt avaldas kirjastus Hea Lugu veel ühe Aitsami raamatu. ${ }^{36}$ Kaheosalise monograafia ja mälestustekogumikuga viis uurimistöö kui mitte lõpule, siis vähemalt vahefinišisse Toomas Karjahärm, kelle esimene uurimus sel teemal oli ilmunud juba revolutsiooni 70 . aastapäeva eel. ${ }^{37}$ Eraldi on uuritud ka mõnd kitsamat sündmust, nt Uue turu veresauna. ${ }^{38}$ Väärilise tähelepanuta on jäänud üks hiljutine allikapublikatsioon 1905. aasta revolutsiooni aastatest - Eestimaa rüütelkonna protokollid aastatest $1905-1907 .{ }^{39}$

Ajavahemik 1905/1907 kuni 1914 on seni põhjalikuma üldkäsitluseta, kuid seda perioodi on uuritud nii järelloona 1905. aasta revolutsioonile kui ka eelloona Esimesele maailmasõjale. Mõistagi on sellest ajastust juttu paljudes mälestustes, sest tegu oli 1870.-1890. aastatel sündinud ning sõdadevahelisel ajal Eesti elus aktiivselt tegutsenud põlvkonna noorusajaga. Tartu ülikooli ja Tartus tegutsenud eraülikoole Esimese maailmasõja eel ja ajal on uurinud Sirje Tamul. ${ }^{40}$ Ajajärk 1905. aasta revolutsioonist Esimese maailmasõjani on tähtis kas või Tallinna kiire tõusu vaates Riia ja Helsingi vahelisest unisest provintsipealinnast suureks mereväebaasiks ja sõjatööstuskeskuseks, aga ka eestluse keskuseks Tartu kõrvale, kuid see on jäänud eelnenud ja järgnenud murrangulisemate sündmuste varju.

Osalt sõjaeelse Eesti Vabariigi ja Nõukogude anneksiooni aja ajalookirjutuse pärandina oli kaua vaeslapse osas Esimese maailmasõja ajalugu. Kui eestlaste jaoks varjutas seda riigiloomine, Saksa okupatsioon ja Vabadussõda, siis sovetlikus ajalookirjanduses polnud Esimese maailmasõja ajalugu palju muud kui 1917. aasta Oktoobrirevolutsiooni eellugu ja Vene kodusõja esimene aasta. Saksa okupatsioo-

35 Tallinna Uuel turul mälestati veresauna ohvreid. 29.10.2000. Eesti Vabariigi Presidendi kantselei ametlikud teated 1992-2001, https://vp1992-2001.president.ee/est/ateated/AmetlikTeade.asp?ID= 1414 (04.07.2020).

${ }^{36}$ Aitsam, M. 1905. aasta revolutsioon ja selle ohvrid Eestis. Ilmamaa, Tartu, 2011; Aitsam, M. Jõulud Vigalas: 1905. a Läänemaal: Eel- ja järellugudega: Isiklikke mälestusi ja uurimusi. Hea Lugu, Tallinn, 2014.

${ }^{37}$ Karjahärm, T. 1905. aasta Eestis: Massiliikumine ja vägivald maal. Argo, Tallinn, 2013; Karjahärm, T. 1905. aasta Eestis: Sotsialistid ja terroristid. Argo, Tallinn, 2013; 1905. aasta Eestis: Mälestused. Koost ja komm T. Karjahärm. Argo, Tallinn, 2016. Sovetiaegne käsitlus: Karjahärm, T., Pullat, R. Eesti revolutsioonitules 1905-1907. Eesti Raamat, Tallinn, 1975.

${ }^{38}$ Kann, L. Tulistamine Tallinna Uuel turul 1905. aasta 16. oktoobril. - Tuna, 2015, 3, 90-97.

${ }^{39}$ Protokolle der Estländischen Ritterschaft 1905-1907, Halbband 1: Protokolle der Estländischen Ritterschaft 1905-1906; Berichte an den ordentlichen Landtag Januar 1905, Halbband 2: Protokolle der Estländischen Ritterschaft 1907; Protokolle des Landratskollegiums 1905-1907; Anträge und Entwürfe 1905-1907. Hrsg. v. T. Frhr. v. Dellingshausen, H. v. Wistinghausen. (Ex fontibus Archivi Historici Estoniae, 5.) Rahvusarhiiv, Tartu, 2016.

40 Tamul, S. Тарту и его университеты (1905-1918 годы). - Университет и город в России в начале XX века. Под ред. Т. Маурер, А. Дмитриева. Новое литературное обозрение, Москва, 2009, 584-702. 
nigi vaadeldi pigem kohalikus või siis Vene kodusõja kontekstis, sest tõepoolest 1918. aasta märtsis olid Nõukogude Venemaa ja Keskriigid omavahel rahu sõlminud. Sõjaalguse 90. aastapäeval 2004. aastal korraldati Laidoneri muuseumis küll näitus, kuid kirjasõnas tähtpäev suuremat tähelepanu ei pälvinud.

Saja aasta juubeli puhul 2014-2018 oli Esimene maailmasõda aga Eesti Ajalooarhiivi toimetiste kahe köite, kolme Eesti sõjaajaloo aastaraamatu ning ühe Ajaloolise Ajakirja teemanumbri aineks, kokku ligi kaks tuhat lehekülge eelretsenseeritud uurimusi, lisaks artiklid teistes ajalooajakirjades ${ }^{41}$ Ajalooarhiivi toimetised käsitlesid Eesti elu eri valdkondi alates majandusest ja kirikuelust kuni invaliidide toetamiseni sõjajärgses Eestis ja sõjaveteranide saatuseni NKVD küüsis pärast Eesti okupeerimist 1940. aastal. Sõjaajaloo aastaraamatud sisaldavad enamasti teiste riikide ajaloolaste tekste, sest aastaraamatute lähtekoht on iga-aastane temaatiline rahvusvaheline sõjaajalookonverents. Eraldi väärivad nimetamist Aadu Musta raamat baltisakslaste represseerimisest Esimese maailmasõja ajal, Liisi Esse doktoritöö tsaariarmees teeninud eesti sõdurite sõjakogemusest ning Rahvusarhiivi publitseeritud mahukas kogumik eesti sõdurite kirjade, päevikukatkete ja mälestustega. ${ }^{42}$ Eestimaa rüütelkonna kui avalik-õigusliku institutsiooni ja maaomavalitsuse lõpu üksikasjad Esimese maailmasõja ja Eesti riigi loomise ajal toob esile Eestimaa rüütelkonna protokollide jt rüütelkonna materjalide allikapublikatsioon..$^{43}$ Esimeses maailmasõjas pandi alus Eesti sõjaväe ohvitserikorpusele. Seda teemat on üle veerandsajandi uurinud Mati Kröönström. Lisaks teadusmagistri- ja doktoritööle on ta eesti ohvitserikorpust Esimeses maailmasõjas käsitlenud mitmes põhjalikus artiklis. ${ }^{44}$ Senisest mitmepalgelisemalt on 1918. aasta Saksa okupatsioonist kirjutanud Mart Kuldkepp ${ }^{45}$ kes on tegelenud veel nii eesti sõjavangidele suunatud

${ }^{41}$ Esimene maailmasõda ja Eesti; Esimene maailmasõda ja Eesti II. Mõlemad koost T. Tannberg. (Eesti Ajalooarhiivi toimetised, 22 (29); 24 (31).) Eesti Ajalooarhiiv, Tartu, 2014 ja 2016; I maailmasõda Ida-Euroopas - teistsugune kogemus, teistsugused mälestused; Euroopa pärast I maailmasõda: Rahvusriikide armeede sünd impeeriumide varemetel; Rahvusväeosad I maailmasõjas impeeriumide värbamispoliitikast iseseisvate rahvusriikide relvajõududeni. Peatoim T. Hiio, toim S. Niinepuu (2015 ja 2016) ja K. Piirimäe. (Eesti sõjaajaloo aastaraamat, 5 (11); 6 (12); 8 (14).) Eesti sõjamuuseum - kindral Laidoneri muuseum, Tallinna Ülikooli Kirjastus, Tallinn, 2015; 2016; 2018); Esimene maailmasõda ja selle järelkajad Eestis. Koost M. Kuldkepp, K. Piirimäe, P. Piirimäe. Ajalooline Ajakiri, 2016, 1 (155).

${ }^{42}$ Must, A. Muutugu ja kadugu! Baltisakslased ja Esimene maailmasõda. Tartu Ülikooli Kirjastus, Tartu, 2016; Esse, L. Eesti sõdurid Esimeses maailmasõjas: Sõjakogemus ja selle sõjajärgne tähendus. (Dissertationes historiae Universitatis Tartuensis, 38.) Tartu Ülikooli Kirjastus, Tartu, 2016; Eestlased ilmasõjas: Sõdurite kirju, päevikuid ja mälestusi Esimesest maailmasõjast. Koost T. Tannberg. Rahvusarhiiv, Tartu, 2015.

${ }^{43}$ Protokolle der Estländischen Ritterschaft 1914-1920: Berichte an den ordentlichen Landtag der Estländischen Ritterschaft, Februar 1914, Anträge und Entwürfe; Protokolle des Estländischen Landratskollegiums 1914-1918. Hrsg. v. T. Frhr. v. Dellingshausen ja H. v. Wistinghausen. (Ex fontibus Archivi Historici Estoniae, 3; Halbband 1-2.) Eesti Ajalooarhiiv, Tartu, 2011.

${ }^{44}$ Kröönström, M. Eesti rahvusest kaadriohvitserid Vene armees aastail 1870-1917. - Vene aeg Eestis: Uurimusi 16. sajandi keskpaigast kuni 20. sajandi alguseni. (Eesti Ajalooarhiivi toimetised, 14 (21).) Eesti Ajalooarhiiv, Tartu, 2006, 317-344; Kröönström, M. Tsaariarmees teeninud eesti soost kaadriohvitseride sotsiaalsest päritolust. - Ajalooline Ajakiri, 2000, 3 (110), $43-50$ jt. 
propagandaga Saksamaa sõjavangilaagrites kui ka mitut masti rahvuslike aktivistide tegevusega neutraalses Skandinaavias Esimese maailmasõja ajal. Niisiis on veel puudu kaasaegne sõjanduslik ülevaade Eesti territooriumi rollist Vene strateegias, siin paiknenud Vene üksustest - peale eesti rahvusväeosade, millest on kirjutatud mitu ülevaadet ${ }^{46}$ - ja ka sõjategevusest Eesti alal, eriti saartel 1917. ja 1918. aastal. Kaitseväe Akadeemias ja Balti Kaitsekolledžis on õppeprotsessi eri astmetel kirjutatud küll hulk sõjaajalooalaseid töid, sealhulgas ohvitserikandidaatide ja ohvitseride poolt, kes on ülikoolis ajalugu õppinud, kuid uurimistöö jätkamist teenistusega sobitada on olnud raske. Nii on Eesti sõjaajalooväli jäänud tsivilistide kätte, kellel tihti pole olnud lähemat isiklikku kokkupuudet sõjandusvaldkonnaga, mis nähtub ka uurimisteemade valikust.

\section{AASTAD 1918-1920: RIIGILOOMINE JA VABADUSSÕDA}

1990. aastate lõpul, kui Eesti riigi loomisest ja Vabadussõjast möödus 80 aastat, monograafiaid ei ilmunud, küll aga avaldati mitme sõjaeelse uurimuse või mälestusteraamatu kordustrükk. Tegeldi Vabadussõjas võidelnud eesti ohvitseride nimekirja koostamise ${ }^{47}$ ja Vabadussõja mälestusmärkide saatuse uurimisega. Erandiks olid Karsten Brüggemanni uurimused, ${ }^{48}$ kelle mitte-Eesti-keskset vaatenurka mitte kõik eesti ajaloolased õigeks ei pidanud. Väitlus selle üle, kas rõhutada Vabadussõda ja Eesti riigi sündi eesti rahva kauaaegsete püüdluste viljana või hoopis sündmusena Esimese maailmasõja, Vene ja Saksa impeeriumi lagunemise ning maailmasõja järelsõdade kontekstis, ei ole vaibunud tänini, ehkki kumbki seisukoht teist otse ei välista. Tänapäeval lubab arhiivide avanemine vähemasti Esimest maailmasõda ja enamasti ka vabadussõdu uurida juba kõigi sõdinud poolte arhiiviallikaid kasutades ja eri vaatepunkte arvesse võttes. Ka Teise maailmasõja kohta Euroopas on nüüdseks uurijate käsutuses suur hulk kõigi sõdinud riikide allikmaterjale. See on toonud kaasa - poliitika poolt usurpeeritud mõistet kasutades - ajaloo ümberkirjutamise

${ }^{45}$ Kuldkepp, M. Rahvusliku enesemääramise kaudu Saksamaa külge: Eestlased anneksionistliku Saksa poliitika sihtmärgina 1918. aasta okupatsiooni eel. - Esimene maailmasõda ja Eesti II, 369 433; Kuldkepp, M. Eestlased ja ,eestlase vaenlased“: Survemeetmed baltisakslaste ja nende poolehoidjate vastu Eesti Vabadussõja ajal. - Vabadussõja mitu palet: Sõda ja ühiskond aastatel 1918-1920. Koost ja toim T. Tannberg. (Eesti Rahvusarhiivi toimetised, 3 (34).). Rahvusarhiiv, Tartu, 2019, 365-421.

${ }^{46}$ Ühena esimestest Lokk, V. Eesti rahvusväeosad 1917-1918: formeerimine ja struktuur. Argo, Tallinn, 2008; aga ka Pajur, A. Die estnischen Militäreinheiten 1917-1918. - Forschungen zur baltischen Geschichte, 2016, 10, 136-162; Pajur, A. Eesti rahvusväeosad 1917-1918: Historiograafiline ülevaade; Eesti rahvuslikud väeosad 1918. aasta kevadtalvel. - Esimene maailmasõda ja Eesti II, 9-42; 434-506; Pajur, A. Lisandusi eesti rahvusväeosade „Haapsalu perioodile“. - Tuna, 2019, 1, 55-77; 2, 78-104.

${ }^{47}$ Walter, H., Tojak, T. Nad andsid kõik: Vabadussõjas langenud ohvitserid. SE\&JS, Tallinn, 2000.

${ }^{48}$ Sh 1999. aastal Hamburgi Ülikoolis kaitstud doktoritöö, raamatuna: Brüggemann, K. Die Gründung der Republik Estland und das Ende des „Einen und Unteilbaren Rußland“: Die Petrograder Front des Russischen Bürgerkriegs 1918-1920. (Reihe Forschungen zum Ostseeraum, 6.) Harrassowitz, Wiesbaden, 2002. 
ning enamiku 20. sajandi teisel poolel riikide ajaloopoliitika kehtestatud raamides ja suletud arhiiviuste taga kirjutatu tühistamise või vähemalt aegumise.

Paljud ajalooraamatud on kirjutatud tähtpäevade eel, ajal või järel või ka nendeks puhkudeks tellitud. Eesti riigi ja Vabadussõja 90. ja 100. aastapäevaga seoses ilmus hulk uusi uurimusi. Rahvusarhiiv avaldas kaks kommenteeritud ja põhjalike artiklitega sisse juhatatud allikapublikatsiooni Eesti riikluse alusdokumentidest: „Iseseisvusmanifest“ ja „Eesti riikluse alusdokumendid 1917-1920“.49 Mati Kröönström käsitles oma doktoritöös Eesti sõjaväe juhtkonda Vabadussõjas ${ }^{50}$ Reigo Rosenthali monograafia teemaks oli Johan Laidoneri tegevus Eesti sõjavägede ülemjuhatajana Vabadussõjas. ${ }^{51}$ Rosenthali esimene raamat Vabadussõja ajast, massiivsele arhiiviainesele toetuv, kuid raskepärane „Loodearmee“, oli ilmunud kaks aastat varem. Hiljem on Rosenthali sulest ilmunud ka monograafia sõjaväejuhtkonna ja sisepoliitika vahekorrast Vabadussõja ajal. ${ }^{52}$ Taavi Minnik on uurinud sõjaaegseid repressioone ja terrorit. ${ }^{53}$ Venelased ja teised vähemusrahvad Vabadussõjas ja Eesti sõjaväes sõjajärgsel ajal on üks Igor Kopõtini uurimisteemasid. ${ }^{54}$

2019. aastal avaldas Rahvusarhiiv Vabadussõja aastatele pühendatud artiklikogumiku „Vabadussõja mitu palet“, mille 14 artiklist puudutavad otsest sõjategevust kaks. ${ }^{55}$ Ülejäänutest kujunev tervik annab hea ülevaate paljudest riigi tegevus- ja eluvaldkondadest sõja ajal. Põhjalik monograafia Taani vabatahtlikest Eesti vabadussõjas valmis 2019. aastal dr Mikkel Kirkebækil. ${ }^{56}$ Soome vabatahtlikest kirjutati mitu raamatut juba enne Teist maailmasõda, kuid teema huvitab uurijaid tänini. Soome vabatahtlike liikumise tagamaid ning võitlusi Eesti ja Läti vabadussõjas, aga ka Karjalas ja Ingerimaal kajastab Aapo Roseliuse ja Oula

${ }^{49}$ Eesti! Sa seisad lootusrikka tuleviku lävel, kus sa vabalt ja iseseisvalt oma saatust määrata ja juhtida võid: Eesti riikluse alusdokumendid 1917-1920. Koost A. Pajur. Eesti Ajalooarhiiv, Tartu, 2008; Iseseisvusmanifest: Artikleid, dokumente ja mälestusi. Koost T. Tannberg ja A. Pajur. Rahvusarhiiv, Tartu, 2014.

${ }^{50}$ Raamatuna: Kröönström, M. Kaptenite ja leitnantide sõda: Eesti sõjavõe juhtkoosseis Vabadussõjas 1918-1920. Tänapäev, Tallinn, 2010.

${ }^{51}$ Rosenthal, R. Laidoner - väejuht: Johan Laidoner kõrgema operatiivjuhi ja strateegia kujundajana Eesti Vabadussõjas. Argo, Tallinn, 2008.

${ }^{52}$ Rosenthal, R. Loodearmee. Argo, Tallinn, 2006; Rosenthal, R. Kord ja kohus: Eesti sõjaväejuhtkond Vabadussõja-aegses sisepoliitikas. Argo, Tallinn, 2019.

${ }^{53}$ Minnik, T. Terror ja repressioonid Eesti Vabadussõjas: Historiograafia, allikad ja edasised uurimisvõimalused. - Uurimusi historiograafiast, allikaõpetusest ja institutsioonidest. Koost T. Tannberg. (Eesti Ajalooarhiivi toimetised, 19 (26).) Eesti Ajalooarhiiv, Tartu, 2012, 245-264; Minnik, T. Kontrrevolutsiooni vastu võitlemise komisjonide rollist enamlaste terroripoliitika täide viimisel Eestis 1918-1919. - Acta Historica Tallinnensia, 2015, 1, 51-68.

${ }^{54}$ Kopõtin, I. Katšanovi üksikpataljon. - Väeteenistusest Eestis ja eestlastest väeteenistuses. (Eesti sõjaajaloo aastaraamat, 1 (7).) Eesti sõjamuuseum - kindral Laidoneri muuseum, Tallinna Ülikooli Kirjastus, Tallinn, 2011, 73-101; Kopõtin, I. Rahvuse kool: Eesti rahvusarmee ja vähemusrahvused aastatel 1918-1940. (Uurimusi ja allikmaterjale Eesti sõjaajaloost, 9.) Rahvusarhiiv, Tartu, 2020.

55 Salo, U. Punaarmee lüüasaamine Lõuna-Eestis 1919. aasta jaanuari keskel ja selle mõju olukorrale Lätis. - Vabadussõja mitu palet, 307-338; Veske, J. Lahingud Jõhvi vabastamiseks Eesti Vabadussõjas jaanuaris 1919. - Vabadussõja mitu palet, 339-364.

${ }^{56}$ Kirkebæk, M. Den yderste grænse: danske frivillige i de baltiske uafhængighedskrige 1918-1920, Bd. 2: Krig og efterkrigstid. Lindhardt og Ringhof, København, 2019. 
Silvennoise viimane raamat „Metsik ida“ ${ }^{57}$ Eesti arhiivid on olnud veerand sajandit avatud ja teiste riikide ajaloolased on uurinud ka 20. sajandi Eesti ajalugu, mille allikad erinevalt varasema ajaloo teemadest on suuresti eesti keeles. Aga keelebarjääri ületamisega on tuldud toime. Sellepärast ei ole välisautorite kirjutatu enam sugugi ainult suure ajaloo või regionaalajaloo ääremärkus inglise, saksa või vene keelde tõlgitud eesti ajaloolaste tööde baasil, vaid iseseisev uurimissaavutus.

(Sõja)merenduse uurija Arto Oll kaitses 2018. aastal doktoritöö Eesti mereväest Vabadussõjas. ${ }^{58}$ Ta on põhjalikult käsitlenud ka Eesti ja Suurbritannia sõjalisi suhteid Vabadussõja ajal. ${ }^{59}$ Vabadussõja ajalooga seoses tõstetagu esile veel kaks koguteost, mis on oma teema allikmaterjali ammendanud. Need on Vabadusristi kavaleride biograafiline leksikon ja ülevaade vabadussammaste ajaloost. ${ }^{60}$ Mõlemad raamatud on mõnekümne aasta pikkuses hoolsas kogumis- ja uurimistöös sündinud entsüklopeedilis-biograafilised teatmikud. Tegu on n-ö rakendusajalooga, mille eesmärk ei ole mitte niivõrd üldistus, kuivõrd, vastupidi, täpsuse saavutamine kuni pisimate üksikasjadeni. Ühe autori, Jaak Pihlaku eraldi uurimisteemaks on olnud Eesti-Läti suhted Vabadussõja teenetemärkide (vastastikuse) annetamise taustal. ${ }^{61}$

Senised uurimistulemused võtab kokku tänavu ilmunud uus kaheköiteline Vabadussõja ajalugu, mis oma kitsamalt teemalt avardub ositi Eesti Vabariigi eelloo, aga ka sise- ja välispoliitika ning sõjaasjanduse alguse laiemaks ülevaateks. ${ }^{62}$ Kuid tegu ei ole pelgalt referaadiga varem avaldatust - uurimuse koostamisel töötati uuesti läbi nii Eesti kui ka teiste riikide asjassepuutuvad arhiivimaterjalid ning ka suur hulk uurimusi ja mälestusi, mida ei olnud kasutada varasematel Vabadussõja ajaloo uurijatel.

\section{EESTI VABARIIK 1918/1920-1940}

Eesti Vabariigist enne Teist maailmasõda on viimasel kahel kümnendil üllitatud hulk monograafiaid ja muid käsitlusi paljudel teemadel, alates Riigikogust, välispoliitikast, majandusest, riigi- ja sisekaitsest kuni taksonduse ja kõrtsinduseni.

Sõdadevahelise ajaloo uurimise üks tunnusmärke oli kümmekond aastat väldanud debatt Konstantin Pätsi rollist Eesti iseseisvuse kaotuses aastatel 1939-1940 ning

\footnotetext{
${ }^{57}$ Roselius, A., Silvennoinen, O. Villi itä: Suomen heimosodat ja Itä-Euroopan murros 1918-1921. Tammi, Helsinki, 2019.

${ }^{58}$ Oll, A. Eesti Merevägi Vabadussõjas 1918-1920: Doktoritöö. Tallinna Ülikool, Humanitaarteaduste instituut, Ajaloo, arheoloogia ja kunstiajaloo keskus, 2018.

${ }^{59}$ Oll, A. Eesti sõjalaevastiku olukord ja võimalikud relvahanked Suurbritanniast aastail 1920-1921. Sõjaväe ja tsiviilelanike suhted. (Eesti sõjaajaloo aastaraamat, 2 (8).) Eesti sõjamuuseum - kindral Laidoneri muuseum, Tallinna Ülikooli Kirjastus, Tallinn, 2012, 205-237; Oll, A. Suurbritannia Venemaa-suunalise interventsioonipoliitika tagamaad ja Briti eskaadri saabumine Tallinna 1918. aastal. - Tuna, 2018, 4, 33-56; Oll, A. Suurbritannia seisukohad Eesti suhtes ja Briti eskaadri tegevus Soome lahel 1918-1919. - Vabadussõja mitu palet, 185-233.

${ }^{60}$ Pihlak, J., Strauss, M., Krillo, A. Eesti Vabaduse Risti kavalerid. Koost Jaak Pihlak. Vabadussõja Ajaloo Selts, Viljandi Muuseum, Viljandi, 2016.

${ }^{61}$ Pihlak, J. Karutapjad ja Vabaduse Risti vennad. Viljandi Muuseum, Viljandi, 2010.

${ }^{62}$ Kaasik, P., Vahtre, L., Salo, U. jt. Eesti Vabadussõja ajalugu. 2 kd. Koost ja toim L. Vahtre. (Eesti Sõjamuuseumi - Kindral Laidoneri Muuseumi toimetised, 10/1-2.) Varrak, Tallinn, 2020.
} 
sellestki, kas ta sai NSV Liidust raha ja oli NSV Liidu välisluure (mõju)agent või siis mitte. Pätsi rolli uurimist alustas 1990. aastatel Magnus Ilmjärv, ${ }^{63}$ kelle pikaajaline uurimistöö Eesti ja mitme teise riigi arhiivides vormus ingliskeelseks doktoritööks ${ }^{64}$ ja suurt poleemikat põhjustanud eestikeelseks raamatuks. ${ }^{65}$ Ilmjärve sõnakaim oponent ajaloolaste seas oli Jaak Valge, kes oli oma uurimustes ka ise kriitiliselt käsitlenud Pätsi majandustegevust 1920. aastate alguses ja hiljem 1934. aasta võimuhaaramist. Üks Valge väiteid oli, et Nõukogude asutuste dokumendid, millele Ilmjärv viitas, ei saanud olla tehtud järelduste aluseks. ${ }^{66}$ Teema võttis tasakaalukalt kokku Ago Pajur 2018. aastal ilmunud Konstantin Pätsi biograafias. ${ }^{67}$ Poleemika tolm pole hajunud tänini ja on jõudnud küsimuseni, kas Eesti esimene riigipea ikka väärib monumenti Eesti pealinnas.

Sajandivahetusel publitseeris toonane Riigiarhiiv mitu kommenteeritud dokumendikogumikku põhiliselt 1920. aastate dokumentidest, mis käsitlevad riigiloomist, välispoliitikat ja Eesti välissuhteid. Digiteeritud arhiivide ajastul on need mõneti unustusse vajunud, kuid toovad esile 20 aasta tagused huviobjektid ja uurimisseisu. ${ }^{68}$ Suurema osa kogumikest koostas Heino Arumäe. Ta on kirjutanud kümneid artikleid ja arvustusi sõdadevahelise Eesti ajaloost. Arumäe kitsam uurimisteema on Eesti suhted naaberriikidega, Eesti välispoliitika ja iseseisvuse kaotuse ajastu. ${ }^{69}$ Tema viimane monograafia käsitles Eesti ja Soome suhteid. ${ }^{70}$

2007. aastal alustas Riigikantselei stipendiumide väljaandmist Eesti riigivanemate biograafiate koostamiseks. Nüüdseks on Rahvusarhiivi kirjastamisel ilmunud raamatud August Reist, Otto Tiefist, Konstantin Pätsist ja Jaan Tõnissonist. Need pole mitte ainult klassikalised biograafiad, vaid üksiti ka uurimused ajastust, oludest, poliitikast ning Eesti ja inimeste saatusest. ${ }^{71}$ Stipendiumid on välja antud ka Kaarel

${ }^{63}$ Ilmjärv, M. Konstantin Päts ja Nõukogude Liidu Tallinna saatkond 1925-1934. - Acta Historica Tallinnensia, 1999, 3, 156-223.

${ }^{64}$ Ilmjärv, M. Silent submission.

${ }^{65}$ Ilmjärv, M. Hääletu alistumine: Eesti, Läti ja Leedu välispoliitilise orientatsiooni kujunemine ja iseseisvuse kaotus: 1920. aastate keskpaigast anneksioonini, Argo, Tallinn, 2004; 2. täiend. ja parand. tr. 2010.

${ }^{66}$ Valge, J. Konstantin Päts ja Nõukogude Liidu huvid I-II. - Akadeemia, 2007, 6, 1163-1200; 7, 1453-1484.

${ }^{67}$ Pajur, A. Konstantin Päts: Poliitiline biograafia II: Riigimees (1917-1956). Rahvusarhiiv, Tartu, 2018, 266-276, 298-319, 452 jj.

${ }^{68}$ Eesti ja Soome suhted 1920-1925: Dokumentide kogumik. Koost H. Arumäe; Kaks algust: Eesti Vabariik - 1920. ja 1990. aastad. Koost J. Ant; Eesti Vabariigi sisepoliitika 1918-1920: Dokumentide kogumik. Koost J. Ant, E. Kessel ja A. Pajur; Eesti ja Läti suhted 1920-1925: Dokumentide kogumik. Koost H. Arumäe ja T. Arumäe; Eesti suhted Leedu ja Poolaga: Balti konverentsid 1920 1925: Dokumentide kogumik. Koost H. Arumäe; Eesti Vabariigi sisepoliitika 1921-1929: Dokumentide kogumik. Koost, J. Ant, E. Kessel ja A. Pajur. (Ad fontes, 1, 3, 5, 7, 9 ja 12.) Umara, Tallinn, 1997, 1998, 1999, 1999, 2001 ja Eesti Rahvusarhiiv, Tallinn, 2002.

${ }^{69}$ Vt Arumäe, H. Baasidelepingu eelmäng. - Tuna, 2001, 4, 23-31; 2002, 1, 37-49; Arumäe, H. Jaan ja Ilmar Tõnissoni välispoliitilistest tõekspidamistest Teise maailmasõja eel. - Tuna, 2003, 3, 35-63; Arumäe, H. Ühe illusiooni purunemine: Abipalve Briti valitsusele 1924. aasta detsembris. - Tuna, 2014, 3, 88-103.

${ }^{70}$ Arumäe, H. Eesti ja Soome: Sõjast sõjani. Argo, Tallinn, 2018.

${ }^{71}$ Ant, J. August Rei - Eesti riigimees, poliitik, diplomaat. Rahvusarhiiv, Tartu, 2012; Paavle, I. Õiguse ja omariikluse eest: Otto Tief (1889-1976). Rahvusarhiiv, Tartu, 2014; Karjahärm, T. 
Eenpalu, Friedrich Akeli, Ants Piibu, Jaan Teemanti, Juhan Kuke, Otto Strandmani ja Jüri Jaaksoni akadeemilise biograafia koostamiseks. Kirjutajat ootavad Ado Birki ja Jüri Uluotsa elulugu. ${ }^{72}$

Eesti ümmargused tähtpäevad on võimaldanud mitme ametkonnaajaloo kirjutamise rahastamist. Üks tuumakamaid neist on Jaak Valge monograafia „Eesti parlament 1917-1940“, mis Eesti parlamendi sünni ja kronoloogia kõrval tutvustab ka silmapaistvamaid Eesti parlamendipoliitikuid ning iga parlamendikoosseisu tähtsamaid debatte. ${ }^{73}$ 2019. aastal valmis Rahvusraamatukogus veebiväljaanne riigikogu I koosseisu liikmete elulugudega, mille eelkäijaks võib pidada 20 aasta eest ilmunud teatmikku „Valitud ja valitsenud“ “ ${ }^{74}$ Kunagi saavad ehk kaante vahele kõigi sõjaeelsete riigikogude liikmete elulood - on ju praegu elulooline teave kättesaadavam kui kunagi varem. Ministeeriumide ja asutuste juubeliraamatud on enamasti kirjeldavad. Riigikontrolli mahukas ajalooraamat ilmus 90. aastapäevaks, haridusministeeriumi ja riigikantselei raamatud 100 . aastapäevaks. ${ }^{75}$ Justiitsministeeriumi ajalugu on kirjutatud juba kaks korda, tõsi, samade autorite poolt. ${ }^{76}$ Rahvusraamatukogu 100 aasta ajalugu ilmus paari aasta eest Piret Lotmani sulest. ${ }^{77}$

Sõdadevahelise Eesti majandust ja majanduspoliitikat on pikka aega uurinud Maie Pihlamägi. Tal on ilmunud monograafiad industrialiseerimisest ja väliskaubandusest. ${ }^{78}$ Oma artiklites on ta käsitlenud ka tööhõivepoliitikat, Rahvusvahelise Tööorganisatsiooni mõju sellele jt teemasid. ${ }^{79}$ Jaak Valge alustas samuti uurimustega majanduse ja rahanduse ajaloost. Tema monograafia „Lahtirakendamine“ (2003) käsitles Eesti majanduse väljaviimist Venemaa ja Nõukogude Venemaa

Konstantin Päts: Poliitiline biograafia I: Vabameelne opositsionäär (1874-1916). Rahvusarhiiv, Tartu, 2018; Pajur, A. Konstantin Päts: Poliitiline biograafia II; Aru, K. Jaan Tõnisson - rahvajuht ja riigivanem. 1-2. Rahvusarhiiv, Tartu, 2019.

${ }^{72}$ Stipendium Eesti riigijuhid 1918-1940/1944, https://www.riigikantselei.ee/et/stipendium (04.07.2020).

${ }^{73}$ Valge, J. Eesti parlament 1917-1940: Poliitiline ajalugu. Eesti Rahvusraamatukogu, Tallinn, 2019.

${ }^{74}$ Valitud ja valitsenud: Eesti parlamentaarsete ja muude esinduskogude ning valitsuste isikkoosseis aastail 1917-1999. Koost J. Toomla. Eesti Rahvusraamatukogu, Tallinn, 1999; I Riigikogu liikmed. Koost P. Viljamaa. Eesti Rahvusraamatukogu, Tallinn, 2019; vt ka Valitsused ja riigimehed: TEA entsüklopeedia eriväljaanne. Koost M. Maasing. Tea kirjastus, Tallinn, 2018.

${ }^{75}$ Riigikontroll 1918-2008. Sissevaateid ajalukku, dokumente, artikleid. Koost K. Arjakas, T. Mattson. SE\&JS, Riigikontroll, Tallinn, 2009; Saueauk, M., Rohtmets-Aasa, H. Riigikantselei 1918-2018. Rahvusarhiiv, Tartu, 2018; Haridusministeeriumi sajand: 1918-2018. Koost L. Uuet. Rahvusarhiiv, Tartu, 2018.

${ }^{76}$ Järvelaid, P., Pihlamägi, M. 80 aastat Eesti Vabariigi Justiitsministeeriumi: 1918-1998. Teaduste Akadeemia Kirjastus, Tallinn, 1999; Järvelaid, P., Pihlamägi, M. Justiitsministeerium 100: 1918 2018. Justiitsministeerium, Tallinn, 2018.

${ }^{77}$ Lotman, P. Eesti Rahvusraamatukogu 1918-2018. Eesti Rahvusraamatukogu, Tallinn, 2018.

${ }^{78}$ Pihlamägi, M. Eesti industrialiseerimine 1870-1940. Teaduste Akadeemia Kirjastus, Tallinn, 1999; Pihlamägi, M. Väikeriik maailmaturul: Eesti väliskaubandus 1918-1940. Argo, Tallinn, 2004.

${ }^{79}$ Pihlamägi, M. Esimene nõukogude aasta Eesti majanduses, 1940-1941. - Acta Historica Tallinnensia, 2005, 9, 187-209; Pihlamägi, M. Rahvusvahelise Tööorganisatsiooni standardid ja nende mõju Eesti tööseadusandlusele kahe maailmasõja vahel. - Acta Historica Tallinnensia, 2011, 17, 109-135; Pihlamägi, M. Tasulise puhkuse sisseseadmine Eestis. - Acta Historica Tallinnensia, 2019, 25, 152-169. 
mõjusfäärist ning Eesti rahanduse stabiliseerimisest..$^{80}$ 2017. aastal kaitses Karl Stern doktoritöö mittetariifsetest kaubandusmeetmetest sõdadevahelises Eestis. ${ }^{81}$

Suure osa Eesti majandusest ja tööhõivest moodustas põllumajandus. Põllumajanduse ja maaeluga seonduvatest paljudest teemadest on rohkem tähelepanu pälvinud maareform ja põllumajanduspoliitika laiemalt. Tiit Rosenberg koondas oma tähtsamad uurimused sel teemal kogumiku „Künnivaod“ viiendaks peatükiks. ${ }^{82}$ Eesti asunduspoliitikat sõdadevahelisel ajal, ka ehituskunsti vaatepunktist, on uurinud Elo Lutsepp Eesti Vabaõhumuuseumist. ${ }^{83}$ Etnoloog Heiki Pärdi on taluarhitektuuri kõrval süvenenud ka eesti hügieeni ajalukku 20. sajandil ja varemgi. ${ }^{84}$ Eli Pilve on avaldanud artikli autasumaa annetamisest Vabadussõjas võidelnutele. Ta on uurinud Eesti erakondade agraarpoliitikat maareformi eel ja ajal ning opteerimist Eesti kodakondsusse. ${ }^{85}$ Lisaks Tiit Rosenbergile on baltisakslaste suhtumist maareformi käsitlenud Marju Mertelsmann ja Heidi Lepplaan. ${ }^{86}$ Opteerimisest Eesti kodakondsusse ja kodakondsuspoliitikast 1920. aastate alguses on Helen Rohtmets-Aasa doktoriväitekiri. ${ }^{87}$

Eesti Vabariigi välispoliitikat 1920. aastate esimesel poolel on uurinud Heino Arumäe (vt eespool). Välispoliitika on olnud ka Eero Medijaise peamine uurimis-

${ }^{80}$ Valge, J. Lahtirakendamine: Eesti Vabariigi majanduse stabiliseerimine 1918-1924. Rahvusarhiiv, Tallinn, 2003.

${ }^{81}$ Stern, K. Mittetariifsete kaubandusmeetmete rakendamine 1930. aastatel Eesti Vabariigi näitel. (Dissertationes historiae Universitatis Tartuensis, 43.) Tartu Ülikooli Kirjastus, Tartu, 2017; vt ka Stern, K. Valuutakontrolli rakendamine Eestis 1930. aastatel. - Ajalooline Ajakiri, 2017, 1, 79 102.

${ }^{82}$ Rosenberg, T. Agraarküsimus ja 1919. aasta maareform Eestis: põhjused, eeldused ja tulemused; Eesti 1919. aasta maareformi historiograafia; Eesti 1919. aasta maareform: Võrdlusjooni Ida- ja Kesk-Euroopa maadega ja Baltisaksa põllumehed Eesti Vabariigis ja Läänemaal 1919-1939. - Rosenberg, T. Künnivaod. Uurimusi Eesti 18.-20. sajandi agraarajaloost. (Õpetatud Eesti Seltsi kirjad, 9.) ÕES, Tartu Ülikooli Kirjastus, Tartu, 2013, 373-378, 379-400, 401-417 ja 418-454.

${ }^{83}$ Lutsepp, E. Asunduspoliitikast Eesti Vabariigis: Asundusameti tegevus 1929-1941. - Ajalooline Ajakiri, 2007, 3/4 (121/122) 443-462; Lutsepp, E. Suunatud sotsiaalne mobiilsus: Uudismaa-asunike valimine 1930. aastatel Pillapalu ja Lepplaane asunduse näitel. - Suitsutare: Valitud artiklid, 5. Eesti Vabaõhumuuseum, Tallinn, 2010.

${ }^{84}$ Pärdi, H. Kasimata talupojad ja kabedad intelligendid: Hügieeniolud 20. sajandi alguse Eesti külas. - Tuna, 2002, 4, 103-117; Pärdi, H. Ülevaade Eesti taluhoonestusest 20. sajandi alguses 1929. aasta põllumajandusloenduse andmeil. - Eesti taluarhitektuur: Püsiv ja muutuv. (Eesti Vabaõhumuuseumi toimetised, 5.) Eesti Vabaõhumuuseum, Tallinn, 2016, 45-76.

${ }^{85}$ Pilve, E. Maa, vabaduse eest. - Akadeemia, 2008, 2, 301-338; Pilve, E. „Millele nad lootsid?“ Eesti Rahvaerakonna ja Eesti Maarahva Liidu maapoliitika kujunemine 1919. aasta maaseaduse eel I-II. - Akadeemia, 2017, 2, 239-259; 3, 413-438.

${ }^{86}$ Mertelsmann, M., Mertelsmann, O. Landreform in Estland 1919: Die Reaktion von Esten und Deutschbalten. (Tartu historische Studien, 2.) Kovač, Hamburg, 2012; Lepplaan, H. „Mein Haus, mein Land, mein Erb und Eigen“: Deutsche Reaktionen auf das estnische Agrargesetz 1919. - Forschungen zur baltischen Geschichte, 2012, 7, 141-167.

${ }^{87}$ Rohtmets-Aasa, H. Eesti Vabariigi sisserändepoliitika aastatel 1920-1923. (Dissertationes historiae Universitatis Tartuensis, 33.) Tartu Ülikooli Kirjastus, Tartu, 2014; vt ka Rohtmets-Aasa, H. The repatriation of Estonians from Soviet Russia in 1920-1923: A test of Estonian citizenship and immigration policy. - Journal of Baltic Studies, 2011, 42, 2, 169-187; Rohtmets-Aasa, H. Kättemaks põlisele vaenlasele? Baltisakslaste kodakondsusküsimus vastloodud Eesti Vabariigis. - Ajalooline Ajakiri, 2010, 1 (131), 37-57. 
teema: välisesindused ${ }^{88}$ Eesti suhted Soome ja Balti riikide, aga ka Nõukogude Venemaa, Ühendkuningriigi ja USA-ga ning luureajalugu sellega seonduvalt. ${ }^{89} \mathrm{Ta}$ on kirjutanud Eesti neutraliteedist, mittetunnustamispoliitikast ja õiguslikust järjepidevusest, välispoliitika kajastamisest Eesti ajalehtede karikatuuridel jm..$^{90}$ Vahur Made doktoritöö oli Eestist Rahvasteliidus..$^{91}$ Tema hilisemad artiklid käsitlevad Eesti olukorda külma sõja ajal ja Eesti eksiilvälispoliitikat. ${ }^{92}$ Koos Eero Medijaisega avaldasid nad kogumiku Eesti välispoliitikast ajaloo murranguhetkedel ${ }^{93}$ Made oli ka üks koguteose, mille teemaks oli Balti küsimus külma sõja ajal, koostajaid ja autoreid. ${ }^{94}$ Eesti ning Aafrika ja Aasia maade suhete üksikküsimusi on lahanud Karin Hiiemaa ja Martin Hallik, ${ }^{95}$ kuid selleteemalise monograafiani pole veel jõutud. Eesti Vabariigi välisteenistuse liikmete kohta 20. sajandil on olemas biograafiline leksikon. ${ }^{96}$ Biograafilised teatmikud on ilmunud ka kohtunike ja teiste kohtuametnike kohta, samuti ilmus 2005. aastal advokatuuri ajalugu koos advokaatide biograafilise leksikoniga. ${ }^{97}$

${ }^{88}$ Vt Medijainen, E. Saadiku saatus.

${ }^{89}$ Medijainen, E. Birgiaadist: Eesti sidemetest ja Roman Birgi rollist Nõukogude vastuluure operatsioonis „Trust“ aastail 1922-1927. - Luuramisi: Salateenistuste tegevusest Eestis XX sajandil: Artiklite ja dokumentide kogumik. Koost T. Noormets. Kistler-Ritso Eesti Sihtasutus, Tallinn, 1999, $67-90$.

${ }^{90}$ Medijainen, E. Oskar Kallas versus Foreign Office. - Oskar Kallas: Artikleid Oskar Kallase elust ja tööst. Eesti Kirjandusmuuseum, Tartu, 1998, 217-244; Medijainen, E. Maailm prowintsionu peeglis: Rahvusvahelised suhted ja Eesti välispoliitika karikatuuridel 1919-1940. Kleio, Tartu, 1998; Medijainen, E. The Tartu peace treaty and permanent neutrality of Estonia. - Border changes in 20th century Europe. Ed. by E. Medijainen, O. Mertelsmann. Lit-Verlag, Berlin, 2010, 183-202; Medijainen, E. Balti riikide de iure järjepidevus noateral: Ameerika Ühendriikide välispoliitika ja Balti küsimus 1940-1945. - Ajalooline Ajakiri, 2010, 2 (132), 153-190; Medijainen, E. Ameerika Ühendriikide de iure tunnustus Balti riikidele 1922 - väärtuspõhine otsus või majanduslik kalkulatsioon? - Ajalooline Ajakiri, 2011, 2 (136), 123-152; Medijainen, E. Raudse eesriide lõimed: Propaganda, avalik arvamus ja Baltikum 1939-1944. SE\&JS, Tallinn, 2018.

${ }^{91}$ Made, V. Eesti ja Rahvasteliit; raamatuna Made, V. Külalisena maailmapoliitikas: Eesti ja Rahvasteliit 1919-1946. Tartu Ülikooli Kirjastus, Tartu, 1999.

92 Made, V. Finland and the Baltic question during the Cold War: A non-declaration Policy. - The Baltic Sea region and the Cold War. Ed. by O. Mertelsmann, K. Piirimäe. (Tartu Historical Studies, 3.) Peter Lang, Frankfurt a. M., 2012, 125-140; Made, V. To be anti-communist or anti-soviet? The People's Republic of China as a dilemma for the Estonian exiled diplomats during the Cold War period. - Samas, 163-180; Made, V. Külma sõja aegne Saksamaa ja Ida-Euroopa: Karl Selteri, Ludvig Jakobseni ja Elmar Reisenbergi raportid Eesti vabariigi peakonsulaadile New Yorgis. - Nõukogude Eesti külma sõja ajal. Koost T. Tannberg. (Eesti Ajalooarhiivi toimetised, 23 (30).) Eesti Ajalooarhiiv, Tartu, 2015, 262-278.

${ }^{93}$ Estonian foreign policy at the cross-roads. Ed. by E. Medijainen, V. Made. (Kikimora publications, Series B, 26.) Aleksanteri Institute, Helsinki, 2002.

${ }^{94}$ The Baltic Question during the Cold War. Ed. by J. Hiden, V. Made, D. J. Smith. (Cold War history series, 20.) Routledge, London, New York, 2008.

${ }^{95}$ Sh Hallik, H. Tartu ülikooli õppejõudude ja kasvandike osast humanitaarorientalistikas (18021940). (Dissertationes historiae Universitatis Tartuensis, 4.) Tartu Ülikooli Kirjastus, Tartu, 2001.

${ }^{96}$ Eesti välisteenistus: Biograafiline leksikon 1918-1991. Koost T. Mulla, P. Pillak, J. Trei, H. Vilbiks. Välisministeerium, Tallinn, 2006.

${ }^{97}$ Anepaio, T. Kohtunikud, kohtu-uurijad ja prokurörid 1918-1940: Biograafiline leksikon. Tartu Ülikooli Kirjastus, Tartu, 2017; Vahtre, L. Eesti Advokatuuri ajalugu 1919-1994. Ilo, Tallinn, 2005. 
Kui jätta kõrvale põrandaalused kommunistid, keda vaadeldakse peamiselt siseja välisjulgeoleku probleemina või osana 1940. aastal alanud Nõukogude okupatsiooni eelloost, on Eesti poliitajaloo uurijate tähelepanu keskpunktis olnud 1934. aasta võimuhaaramine, vabadussõjalased ja sotsialistid. Jaak Valge monograafia „Punased I“ käsitleb Eesti pahempoolsete sotsialistide kujunemislugu ning nende rolli põrandaaluste kommunistide ja NSV Liidu käepikendusena. ${ }^{98} \mathrm{Ta}$ on kirjutanud ka 1930. aastate alguse poliitilisest kriisist ja põhiseaduse referendumitest ning Konstantin Pätsi võimuhaaramisest. ${ }^{99}$

Mitut uurijat on köitnud Eesti sisejulgeoleku ajalugu. Kergemaks sissejuhatuseks teemasse olid politseimuuseumi juhataja Mai Kriki raamatud. ${ }^{100}$ Reigo Rosenthali ja Marko Tammingu kaks mahukat monograafiat sala- ja eriteenistuste tegevusest põhinevad suurel arhiivitööl. ${ }^{101}$ Ülevaatlik kokkuvõte Eesti ja teiste riikide salateenistuste tegevusest Eestis alates Eesti riigi loomisest kuni laulva revolutsioonini on 1999. aastal ilmunud artiklikogumik „Luuramisi“ ${ }^{102}$ 2013. aastal avaldas Ivo Juurvee oma doktoritöö põhjal raamatu riigisaladuse kaitsest Eesti Vabariigis. ${ }^{103}$

Suurim sisejulgeolekukriis sõdadevahelises Eestis oli 1924. aasta 1. detsembri kommunistlik putšikatse. Sovetlikus ajalookäsituses nimetati seda proletariaadi (nurjunud) ülestõusuks, ${ }^{104}$ paguluses ja pärast iseseisvuse taastamist aga putši- või mässukatseks. ${ }^{105}$ Usuteadlane ja ajaloolane Vello Salo soovitas aga kasutada nimetust ,,invasioonikatse“, osutamaks sellele, et operatsioon kavandati Moskvas ja Leningradis ning et NSV Liidust saadetud juhid ja löögimehed olid NSV Liidu kodanikud. Putšikatse 75. aastapäevaks avaldati artiklikogumik „Kas nad lahkusid Moskva rongiga?"“. ${ }^{106}$ Selleks ajaks oli parteiarhiiv avatud ja uurijad said kasutada ka eesti kommunistide Venemaa organisatsioonide materjale, mille hulgas oli palju

98 Valge, J. Punased I. Tallinna Ülikooli Eesti Demograafia Instituut, Rahvusarhiiv, Tallinn, 2014.

99 Valge, J. Tee esimese rahvahääletuseni. - Tuna, 2016, 4, 60-77; Valge, J. Tee teise rahvahääletuseni: ekslike otsuste paraad. - Tuna, 2017, 2, 20-36; Valge, J., Johanson, A. Artur Sirgu hukkumise versioonid. - Tuna, 2018, 4, 57-67; Valge, J., Gortfelder, M. Eesti ühiskonna poliitilised hoiakud murranguaastatel 1932-1934. - Ajalooline Ajakiri, 2018, $2 / 3$ (164/165), 145-174.

${ }^{100}$ Krikk, M. Nemad juhtisid Eesti politseid 1918-1940. M. Krikk, Tallinn, 1998; Krikk, M. Eesti politsei loomine ja areng 1918-1940. Olion, Tallinn, 2001; Krikk, M. Eesti poliitiline politsei 1920-1940. Olion, Tallinn, 2002; Krikk, M. Eesti kriminaalpolitsei 1920-1940. Olion, Tallinn, 2007.

${ }^{101}$ Rosenthal, R., Tamming, M. Sõda pärast rahu: Eesti eriteenistuste vastasseis Nõukogude luure ja põrandaaluste kommunistidega 1920-1924. SE\&JS, Tallinn, 2010; Rosenthal, R., Tamming, M. Sõda enne sõda: Nõukogude eriteenistuste tegevusest Eestis kuni 1940. aastani. SE\&JS, Tallinn, 2013.

${ }^{102}$ Luuramisi: Salateenistuste tegevusest Eestis XX sajandil.

${ }^{103}$ Juurvee, I. Rääkimine hõbe, vaikimine kuld: Riigisaladuse kaitse Eesti Vabariigis 1918-1940. SE\&JS, Tallinn, 2013.

${ }^{104} \mathrm{Vt}$ nt Sunila, A. Eesti proletariaadi relvastatud ülestõus 1. detsembril 1924. Eesti Riiklik Kirjastus, Tallinn, 1961.

${ }^{105}$ Vt nt Rebas, H. Probleme des kommunistischen Putschversuches in Tallinn am 1. Dezember 1924. - Annales Societatis Litterarum Estonicae in Svecia IX, 1980-1985. Kompendietryckeriet, Stockholm, 1986, 161-200.

${ }^{106}$ Kas nad lahkusid Moskva rongiga? 1. detsember 1924: Artikleid ja dokumente. Koost J. Ant. Koolibri, Tallinn, 1996. 
dokumente putši ettevalmistamisest ja aruteludest selle nurjumise põhjuste üle. 1924. aasta invasioonikatset on uuritud hiljemgi. ${ }^{107}$ Isikuloolisest perspektiivist käsitleb kommunistlikku liikumist Eestis sõdadevahelisel ajal Mari-Leen Tammela doktoriväitekiri. ${ }^{108}$ Autoritaarse ajastu valitsemiskorraldusest on kirjutanud Peeter Kenkmann. ${ }^{109}$

21. sajandil on uut tähelepanu pälvinud propagandaajalugu, sealhulgas riikliku sise- ja välispropaganda oma. Riiklik propaganda Pätsi-aegses Eestis seisnes peaasjalikult oma rahvale suunatud üldrahvalikes aktsioonides, alates kodukaunistamisest ja majalippude levitamise kampaaniast kuni isiku- ja kohanimede eestistamiseni, aga ka näiteks filmitsensuuris ning kirjanduse ja ajakirjanduse järeltsensuuris. Autoritaarse valitsemiskorra aegsest riikliku propaganda talitusest kirjutas (teadus)magistritöö Laura Vaan. ${ }^{110}$ Ühe artikli propagandatalitusest on kirjutanud ka siinkirjutaja. ${ }^{111}$

Eesti sõjaväe ajalugu on uurinud mitu ajaloolast ning mõistagi on teema pälvinud ajaloo populariseerijate tähelepanu; viimaste saavutused jäävad väljapoole praeguse artikli vaadet. Kõikehõlmavat üldistavat monograafiat Eesti relvajõududest sõdadevahelisel ajal ikka veel pole. Üks esimesi tänapäevaseid käsitlusi Eesti riigikaitsepoliitikast on juba viidatud Ago Pajuri monograafia, ${ }^{112}$ millele 2013. aastal lisandus Urmas Salo allikapublikatsioon Eesti Riigikaitse Nõukogu protokollidest. ${ }^{113}$ Igor Kopõtin ja Leho Lõhmus avaldasid mahuka käsitluse Eesti sõjaväe pioneeripataljoni ajaloost, millega ühenduses ilmus artikkel Eesti-Läti sõjalisest koostööst pioneerinduse valdkonnas. ${ }^{114}$ Kopõtini doktoritöö on vähemusrahvustest Eesti sõjaväes sõdadevahelisel ajal. ${ }^{115}$ Sõjaväelist haridust ja väljaõpet on uurinud Andres Seene ja Kaarel Piirimäe. Lisaks doktoritööle ohvitseride väljaõppest on esimene koos-

${ }^{107}$ Hiio, T. The Communist coup attempt in Estonia on 1 December 1924: The last but one attempt at world revolution? - Om læring og indsigt fra krig: Isted 1850 til Musa Qala 2006, 2. Verdun 1914 til Libanon 2006. Ed. by M. H. Clemmesen. Syddansk Universitetsforlag, Odense, 2018, 113-158.

${ }^{108}$ Tammela, M.-L. Isikulooline perspektiiv Eestimaa Kommunistliku Partei ajaloos 1920-1940. (Dissertationes historiae Universitatis Tartuensis, 45.) Tartu Ülikooli Kirjastus, Tartu, 2018.

${ }^{109}$ Kenkmann, P. „Universaalne valitsemisvahend“: Kaitseseisukord Eesti Vabariigis aastatel 1938 1940. - Tuna, 2018, 1, 20-38; Kenkmann, P. 1937. aasta põhiseadus - autoritaarse režiimi reformimise katse. - Tuna, 2013, 1, 70-89; Kenkmann, P. Kas 1933. aasta põhiseadus lubas autoritaarset valitsemist? - Tuna, 2009, 3, 42-49.

${ }^{110}$ Vaan, L. Propagandatalitus Eesti Vabariigis autoritaarsel ajajärgul: Magistritöö. Tartu Ülikool, Filosoofia teaduskond, Ajaloo osakond, Eesti ajaloo õppetool, 2005.

111 Нiio, Т. Служба государственной пропаганды Эстонской республики в 1934-1940 гг. - Образ Другого: Страны Балтии и Советский Союз перед Второй мировой войной. Сост. Р. Крумм, Н. Ломагин, Д. Ханов. РОССПЭН, Москва, 2012, 31-57.

${ }^{112}$ Eesti riigikaitsepoliitika aastail 1918-1934.

${ }^{113}$ Salo, U. Riigikaitse Nõukogu protokollid 1933-1939: Allikapublikatsioon. (Uurimusi ja allikmaterjale Eesti sõjaajaloost, 6.) Eesti Ajalooarhiiv, Tartu, 2013.

${ }^{114}$ Kopõtin I., Lõhmus, L. Eesti sõjaväe pioneeripataljon: Areng ja koostöö 1917-1940. Grenader, Tallinn, 2012; Kopõtin, I., Engīzers, E. Eesti ja Läti sõjalis-tehniline koostöö aastatel 1919-1940 pioneeriväeosade näitel. - Eesti sõjaajaloo aastaraamat, 2013, 3 (9), 155-199.

115 Kopõtin, I. Rahvuslus ja lojaalsus Eesti sõjaväes aastatel 1918-1940 vähemusrahvuste näitel. (Tallinna Ülikooli humanitaarteaduste dissertatsioonid, 46.) Võrguteavik, Tallinna Ülikool, 2018; ja monograafiana: Rahvuse kool: Eesti rahvusarmee ja vähemusrahvused aastatel 1918-1940. 
tanud koguteose sõjaväe tehnikakoolist ning publitseerinud Eesti ohvitseride sõdadevahelisel ajal kirjutatud artikleid ja konspekte. ${ }^{116}$ Kaarel Piirimäe uurimustest tõstetagu esile artikkel Vabadussõja pärandist 1930. aastate väljaõppes. ${ }^{117}$ Igor Kopõtin on kirjutanud ka põlvkondade vastuolust sõjaväelises hariduses aastatel 19191940. ${ }^{118}$ Eesti sõjaväevormi ajaloo sõdadevahelisel perioodil võttis kokku Ülle Krafti koostatud põhjalik uurimus. ${ }^{119}$

Mitme uurija tähelepanu on pälvinud Eesti rahvusvähemused ja vähemusrahvuste poliitika. Teise maailmasõja lõpuks kaotas Eesti oma saksa ja rootsi vähemusrahvused; lisaks holokaustis mõrvatud tuhandele Eesti juudile ei pöördunud kodumaale tagasi ka paljud Nõukogude tagalas holokaustist pääsenud Eesti juudid. 1925. aasta kultuuromavalitsuse seaduse pakutud võimalust kultuuromavalitsuse valimiseks olid kasutanud baltisakslased ja juudid. Saksa kultuuromavalitsust käsitles Kaido Lauritsa magistritöö. ${ }^{120}$ Eesti juutide ajaloost ja saatusest on kirjutanud Eugenie Gurin-Loov, suure hulga materjale koondas raamatuks Eesti Juudi Muuseumi looja Mark Rõbak (Rybak). ${ }^{121}$ Vähetuntud teavet sisaldavad ka kaks Eesti Tel Avivi saatkonna initsiatiivil avaldatud konverentsitrükist. ${ }^{122}$ Ehkki on avaldatud hulk mälestusi, ei ole seni kokkuvõtvat uurimust Eesti juutide ajaloost.

20. sajandil rändas Eestist välja, põgenes või viidi vangide ja küüditatutena Venemaale kümneid tuhandeid inimesi. Eesti diasporaa on arvukas. Diasporaa eri osad sündisid eri aegadel ja mitmesugustel põhjustel ning on seetõttu erinevad uurimisobjektid: tsaariaegsed sunnitöölised ja väljarändajad ning nende järeltulijad, Nõukogude okupatsiooni ajal Siberisse, Kaug-Itta ja Põhja-Venemaale vangidena veetud

${ }^{116}$ Seene, A. Eesti sõjaväe ohvitseride ettevalmistamise süsteemi kujunemine ja areng 1919-1940. (Dissertationes historiae Universitatis Tartuensis, 22.) Tartu Ülikooli Kirjastus, Tartu, 2011; Eesti Vabariigi Sõjaväe Tehnikakool 1920-1923/1936-1940: Uurimusi, mälestusi ja dokumente. Koost ja toim A. Seene. (KVÜÕA toimetised, 6.) Kaitseväe Ühendatud Õppeasutused, Tartu, 2006.

${ }^{117}$ Piirimäe, K. Preparing for war in the 1930s: The myth of the Independence War and Laidoner's „active defence“. - Visions of war: Experience, imagination and predictions of war in the past and the present. (Eesti sõjaajaloo aastaraamat, 7 (13).) Eesti sõjamuuseum - kindral Laidoneri muuseum, Tallinna Ülikooli Kirjastus, Tallinn, 2018, 116-150.

${ }^{118}$ Kopõtin, I. A Generational shift: The military history crisis in the Estonian military education 1919-1940. - The past - a soldier's guide for the present? Experience, history and theory of war in military education. (Eesti sõjaajaloo aastaraamat, 9 (15).) Eesti sõjamuuseum - kindral Laidoneri muuseum, Tallinna Ülikooli Kirjastus, Tallinn, 2019, 66-113.

119 Kraft, Ü., Boltowsky, T., Lõhmus, L. Eesti sõjaväevormi lugu 1918-1940. Koost Ü. Kraft. (Eesti Sõjamuuseumi - Kindral Laidoneri Muuseumi toimetised, 9.) Eesti sõjamuuseum - kindral Laidoneri muuseum, Viimsi, 2019.

${ }^{120}$ Laurits, K. Saksa Kultuuromavalitsus Eesti Vabariigis 1925-1940: Monograafia ja allikad. (Ad fontes, 16.) Rahvusarhiiv, Tallinn, 2008.

${ }^{121}$ Gurin-Loov, E. Tallinna Juudi Gümnaasium 1923-1940 (1941): Ajalugu, mälestused, meenutused. Ajakiri Horisont, Tallinn, 1998; vt Eesti Juudi Muuseum = Еврейский музей Эстонии = Estonian Jewish Museum, https://muuseum.jewish.ee (04.07.2020). Vt ka Weiss-Wendt, A. On the margins: About the history of Jews in Estonia. CEU Press, Budapest, New York, 2017.

${ }^{122}$ Exceptional Estonia - An oasis of tolerance: Documents pertaining to Jewish cultural autonomy in the Republic of Estonia between the two world wars (1918-1940); An overview on the aliyah of Estonian Jews in the 20th century from Estonia to Eretz Israel: With love for both. Embassy of Estonia in Tel Aviv, Tel Aviv, Tallinn, 2015; 2016. 
või küüditatud, parema elu otsingul 20. sajandi esimesel poolel Ameerikasse väljarännanud, 1939-1940 Saksamaale ümber asunud baltisakslased ja 1941. aasta järelümberasujad ning 1944. aastal naasnud Nõukogude okupatsiooni eest põgenenud. ${ }^{123}$ 1999. aastal ilmus Raimo Raagilt lühiülevaade kogu eesti diasporaast. ${ }^{124}$ Venemaale välja rännanud eestlaste saatust on pikka aega uurinud Aadu Must. ${ }^{125}$ Etnoloog Aivar Jürgenson on käsitlenud Ladina-Ameerikasse, eeskätt Argentinasse ja Brasiiliasse välja rännanud eestlasi ning ka Kaukaasia ja Siberi eestlaste saatust. ${ }^{126} 1944$. aastal Eestist pagenutest on palju kirjutanud pagulasautorid, kuid sellest on Eestiski väitekirju kaitstud. ${ }^{127}$

Baltisakslaste 1939.-1940. aasta ümberasumist olid baltisaksa autorid põhjalikult uurinud. 1941. aasta järelümberasujatest, eriti mittesakslastest nende seas, on Eestis vähem kirjutatud. Hulk mittesakslastest järelümberasujaid väitis end sõjajärgsel Saksamaal 1944. aasta põgenikeks ja pääses edasi USA-sse, Kanadasse jt riikidesse, mis Saksa kodakondsetel olnuks raskem. Eestis muutus teema aktuaalseks 1990. aastatel, kui seoses omandireformiga kerkis küsimus, kas järelümberasujatel on õigus tagasi saada neile Eesti Vabariigis kuulunud kinnisvara või mitte. Lihtsustatult taandus probleem küsimusele, kas nad olid Saksamaal loetud Saksa kodanikest ümberasujateks või põgenikeks ning kas nende Eestisse jäänud vara Saksamaal kompenseeriti või mitte. Ümberasumise 60. aastapäeval peeti Tallinna Linnaarhiivis selleteemaline konverents, ettekannete põhjal avaldati artiklikogumik. ${ }^{128} 2006$. aastal ilmus Luule Ranna ülevaateartikkel ümber- ja järelümberasumisest. ${ }^{129}$ Viimasel ajal on teemat põhjalikult uurinud Olev Liivik ja Triin Tark. ${ }^{130}$

${ }^{123} \mathrm{Vt}$ ka Jürgenson, A. Vabatahtliku ja sunniviisilise migratsiooni dihhotoomiast migratsiooni makroja mikroteooriate taustal. - Acta Historica Tallinnensia, 2008, 13, 92-117.

${ }^{124}$ Raag, R. Eestlane väljaspool Eestit: Ajalooline ülevaade. Tartu Ülikooli Kirjastus, Tartu, 1999.

${ }^{125}$ Must, A. Eestlaste deporteerimise ajalugu Tomski arhiivis. - Ajalooline Ajakiri, 2001, 4 (111), 5586; Must, A. Venemaa eestlased ja Suur Terror: Elektrooniliste allikapublikatsioonide andmete kriitiline analüüs. - Ajalooline Ajakiri, 2003, 3 (118), 47-84; Must, A. Siber ja Eesti: Jalaraua kõlin. Tartu Ülikooli Kirjastus, Tartu, 2012.

${ }^{126} \mathrm{Vt}$ nt Jürgenson, A. Escape to the West in the memories of Estonians in Argentina: The historical, social and psychological context. - Acta Historica Tallinnensia, 2009, 14, 125-145; Jürgenson, A. Ladina rahva seas: Argentina ja sealsed eestlased. Argo, Tallinn, 2011; Jürgenson, A. Abhaasia eestlaste kodakondsusküsimused Tartu rahulepingu, Moskva rahulepingu ja erinevate kodakondsusseaduste pingeväljas. - Tuna, 2020, 1, 28-49; Jürgenson, A. Siberi eestlaste territoriaalsus ja identiteet. Doktoritöö, Tallinna Pedagoogikaülikool, 2003.

${ }^{127}$ Merivoo-Parro, M. Pursuing Estonianness in Cold War U.S.A.: Education, recreation, humor and overlapping diasporic conditions. (Tallinna Ülikooli humanitaarteaduste dissertatsioonid, 47.) Võrguteavik, Tallinna Ülikool, 2018; Kumer-Haukanõmm, K. Teisest maailmasõjast tingitud Balti pagulaste problemaatika aastatel 1945-1952 Eesti pagulaste näitel. (Dissertationes historiae Universitatis Tartuensis, 25.) Tartu Ülikooli Kirjastus, Tartu, 2012.

${ }^{128}$ Umsiedlung 60: Baltisakslaste organiseeritud lahkumine Eestist: 24. novembril 1999 Tallinna Linnaarhiivis toimunud konverentsi ettekanded. Koost S. Kivimäe. Baltisaksa Kultuuri Selts Eestis, Tallinna Linnaarhiiv, Tallinn, 2000.

${ }^{129}$ Rand, L. Resettlement of the German minority from Estonia 1939-1941. - Estonia 1940-1945, 33-44.

${ }^{130}$ Liivik, O., Tark, T. Okupeeritud Eestist Saksa Reich'i: täiendusi 1941. aasta järelümberasumise uurimisse. - Tuna, 2016, 2, 58-70; Liivik, O. Millisest rahvusest olid 1941. aastal Eestist Saksa- 
Eesti ajaloo uurimise väljal on mõneti tagaplaanile jäänud siinsete venelaste ajalugu sõdadevahelisel ajal. Ühelt poolt on selle põhjuseks vene keele oskuse vähenemine, mis teeb raskemaks nii töö allikatega kui ka tutvumise varasemate uurimistulemustega. Teisalt on eestivenelaste ajaloo uurijad paljuski keele- ja kirjandusteadlased ning slavistid, kelle tööd ei pruugi ajaloolase lugemislauale sattuda. Siinkohal nimetatagu Sergei Issakovi artiklikogumikku venelastest Eestis 1918-1940, ${ }^{131}$ Aurika Meimre doktoritööd Vene emigrantidest literaatidest Eestis ${ }^{132}$ ja Antonia Naela töid vene vaenlase kuvandist sõdadevahelises Eestis muu hulgas karikatuuride näitel. ${ }^{133}$

Viimasena sõdadevahelise Eesti ajaloo süvitsi uuritud valdkondadest nimetatagu autotransporti. Sel teemal kaitses Tallinna Ülikoolis doktoriväitekirja Riho Paramonov. ${ }^{134} \mathrm{Ta}$ on kirjutanud ka igiliikuri leiutamise katsetest Eestis ja naistest taksojuhtidena. ${ }^{135}$ Maanteetranspordi ajaloole keskendub Eesti Maanteemuuseumi aastaraamat. ${ }^{136}$

Viimasel veerandsajandil on sõdadevahelise Eesti ajalugu uuritud põhjalikult, paljudes valdkondades ja mitmest vaatenurgast. Uus kokkuvõte-üldkäsitlus aga ootab veel kirjutajat. „Eesti ajaloo“ VI köite vastavad peatükid põhinevad suuresti 20. sajandi lõpu uurimisseisul ja on osaliselt aegunud. Ülevaate saamine kõige värs-

maale ümberasunud? Rahvuse määramise poliitikatest ja dokumentidest Eesti Vabariigis ümberasumise valguses. - Õpetatud Eesti Seltsi aastaraamat 2016. Õpetatud Eesti Selts, Tartu, 2017, 141-145; Liivik, O., Liibek, T. Viimane peatükk: Baltisakslaste lahkumine Eestist 1939-1941 = Das letzte Kapitel: Die Umsiedlung der Deutschbalten 1939-1941. Argo, Tallinn, 2019; Tark, T. Võimatu missioon ehk miks on 1941. aastal Eestist Saksamaale ümberasunute rahvust keeruline tuvastada. - Acta historica Tallinnensia, 2019, 25, 69-89.

${ }^{131}$ Исаков, С. Русские в Эстонии 1918-1940: Историко-культурные очерки. Компу, Тарту, 1996.

132 Меймре, А. Русские литераторы-эмигранты в Эстонии 1918-1940: На материале пеиодической печати. (Tallinna Pedagoogikaülikooli humanitaarteaduste dissertatsioonid, 6.) Tallinna Pedagoogikaülikooli Kirjastus, Tallinn, 2001; vt ka Belobrovtseva, I., Meimre, A. Sõdadevaheline vene emigratsioon suures ilmas ja väikeses Eestis. - Methis, 2015, 12 (15), 28-46.

${ }^{133}$ Наэль, А. Иллюстрированный „враг“: образ русского „врага“ в печатных изданиях межвоенной Эстонии. (Tallinna Ülikooli humanitaarteaduste dissertatsioonid 32.) Võrguteavik, Tallinna Ülikool, 2017; Меймре, А., Наэль, А. „Здесь русский дух... Здесь Русью пахнет!“: Борьба с русским духом в Таллине в начале 1920-х годов (Реконструкция событий и их отражение в карикатуре). - Slavica Revalensia, 2014, 1, 121-152.

${ }^{134}$ Paramonov, R. Eesti ühiskonna moderniseerumine avaliku privaattranspordi (voorimees ja takso) näitel, 1900-1940. (Tallinna ülikooli humanitaarteaduste dissertatsioonid, 50.) Võrguteavik, Tallinna Ülikool, 2019.

${ }^{135}$ Paramonov, R. Eestlaste perpetuum mobile leiutamise katsed 1870. aastatest 1940. aastani - ühiskonna moderniseerumise ilming. - Acta Historica Tallinnensia, 2013, 1 (19), 27-60; Paramonov, R. Naine kutselise autojuhina: Naiste roll taksonduse arengus maailmasõdadevahelises Eestis. Ariadne Lõng, 2019, 1/2, 16-42.

${ }^{136} \mathrm{Vt}$ nt Seene, A. Eesti teedevõrgu riigikaitselisest ettevalmistamisest 1930. aastatel. - Maanteemuuseumi aastaraamat 2015. Eesti Maanteemuuseum, Tartu, 2016, 112-154; Seene, A. Teetööde mehhaniseerimise esimene kümnend Eestis. - Maanteemuuseumi aastaraamat 2016. Eesti Maanteemuuseum, Tartu, 2017, 110-175; Seene, A. Kuidas valitseda autotransporti? Autotranspordi regulatsiooniprobleeme 1920.-1930. aastatel. - Uurimusi liikumise ja transpordi ajaloost. (Eesti Maanteemuuseumi toimetised, 1 (10).) Eesti Maanteemuuseum, Tartu, 2019, 159-180; Kupits, A. Maanteede Valitsuse katse kaitsta teid: mudel-taluvankri lugu. - Samas, 125-149. 
kemast uurimisseisust eeldab põhjalikke historiograafilisi ja bibliograafilisi teadmisi ning on aja- ja töömahukas.

\section{OMARIIKLUSE KAOTAMINE JA TEINE MAAILMASÕDA (1939-1945)}

Aastad 1939-1941 on Eesti ajaloo üks põhjalikumalt läbi uuritud valdkondi. Okupatsioonivõimude sise- ja välispropaganda vajadusi järgides ja nende ideoloogilistest skeemidest lähtudes alustati uurimistööga Saksa ajal ja jätkati sovetiajal. Iseseisvuse kaotuse loo selgitamine oli ka osa 1940. aastatel alanud eesti pagulaste välisvõitlusest. Alates laulvast revolutsioonist dikteeris uurimissuundi Eesti õigusliku järjepidevuse tõestamise ja eesti rahva Nõukogude Liidu rahvaste vennaliku perega liitumise teesi ümberlükkamise vajadus nii kodumaal kui ka rahvusvaheliselt. Sellele lisandusid okupatsioonide ja maailmasõja inimohvrite kokkuarvamise kõrval katsed analüüsida okupatsiooni põhjustatud majandus- ja keskkonnakahjusid. Teema on endiselt päevakorral. Liiga sügavale kaevumata nimetatagu ainult uurimistulemuste tähtsamad kokkuvõtted. 1980. ja 1990. aastate vahetuse komisjonide kokkuvõtetele järgnes Riigiarhiivi allikapublikatsioon. ${ }^{137}$ Hiljem joonistusid välja mõned kitsamad uurimisteemad: vastastikuse abistamise lepingute (baaside lepingute) sõlmimine 1939. aastal Balti riikide ja NSV Liidu vahel viimase survel, Eesti (ja Läti ja Leedu) okupeerimine 1940. aasta juunis, Eesti ühiskonna forsseeritud sovetiseerimine aastatel 1940-1941, inimkaotused nn esimesel punasel aastal, 1941. aasta küüditamine ja nn suvesõda. Üldise ülevaate iseseisvuse kaotamise ajastust avaldas baaside lepingu 60. aastapäeval Jüri Ant. ${ }^{138}$ Endel Püüa värske uurimus käsitleb Nõukogude sõjaväebaaside jalgu jäänud saarlaste saatust. ${ }^{139}$

Kaks „tõestamisteemat“ olid küsimus sõjalisest okupatsioonist ja 1940. aasta riigivolikogu valimiste seaduslikkusest. Nimelt keskendus Nõukogude ajaloopropaganda 1940. aasta „sotsialistlikule revolutsioonile“ ja Vene välispropaganda räägib tänini Eesti vabatahtlikust liitumisest vabalt valitud riigivolikogu ühehäälsel otsusel. ${ }^{140}$ Seetõttu on põhjalikult uuritud 1939. aastal vastavalt vastastikuse abistamise lepingule Eestisse paigutatud Nõukogude väekontingendi tegevust 1940. aasta kevadsuvel ning alates 1940. aasta 17. juunist Eestisse saadetud „täiendava Punaarmee väekontingendi“ koosseisu ja eesmärke. Samuti on süvitsi läbi uuritud 1940. aasta juuli valimisfarss ja vastukandidaatide aktsioon.

${ }^{137}$ Baasidelepingust anneksioonini: Dokumente ja materjale. Koost J. Ant jt, toim H. Arumäe. Perioodika, Tallinn, 1991.

${ }^{138}$ Ant, J. Eesti 1939-1941: Rahvast, valitsemisest, saatusest. Riiklik Eksami- ja Kvalifikatsioonikeskus, Tallinn, 1999.

${ }^{139}$ Püüa, E. Saarlased Nõukogude sõjaväebaasidel jalus. (Saaremaa Muuseumi toimetised, 11.) Saaremaa Muuseum, Kuressaare, 2020.

${ }^{140}$ Nt Putin, V. The real lessons of the 75th Anniversary of World War II. - The National Interest, 2020, 168, loetav veebis: https://nationalinterest.org/feature/vladimir-putin-real-lessons-75th-anniversary-world-war-ii-162982 (31.07.2020). 
Vene arhiivide osaline avamine ja veebis kättesaadavaks muutmine sel kümnendil on esimese teema käsitlemist lihtsustanud; ${ }^{141}$ teisel teemal võib ajaloolaste töö lugeda vähemalt vahefinišisse jõudnuks. ${ }^{142}$ Aktiivselt on diskuteeritud selle üle, kas Eesti oleks olnud sõjaliselt võimeline ülekaalukale Punaarmeele Soome kombel vastu panema või mitte. Teadaolevate faktide valgel on vastus selge: ei oleks suutnud, ja seda mitte niivõrd sõjaväe viletsa relvastuse ja väljaõppe ning nõrga kaitsetahte tõttu, nagu Eesti valitsuse ja sõjavägede ülemjuhatuse valeotsuste ja süü rõhutajad on väitnud, kuivõrd võimaluste ja jõudude väga suure erinevuse tõttu.

Loomulikult on palju tähelepanu pööratud 1941. aasta juuniküüditamisele - ja mõnevõrra vähem 1940.-1941. aastal arreteeritute saatusele. Küüditatute ja arreteeritute nimekirjad avaldas Memento. ${ }^{143}$ „Esimese punase aasta“ repressioonide kohta on kaks kokkuvõtlikku peatükki kogumikus „Estonia 1940-1945“, ${ }^{144}$ sellega võrreldes põhjalikum ülevaade on raamatus „Sõja ja rahu vahel““. ${ }^{145}$

21. sajandi esimese kümnendi lõpus võeti uurimisseis kokku kolmes koguteoses, mille kirjutamisel osales suurem osa nende teemadega sel ajal tegelenud ajaloolasi. ${ }^{146}$ Okupeeritud Eesti, Läti ja Leedu rahvusvahelis-õiguslikku staatust käsitles õigusteadlase Lauri Mälksoo Berliinis Humboldti Ülikoolis kaitstud doktoriväitekiri. ${ }^{147}$

14115 aasta tagust uurimisseisu ja küsimusi peegeldab hästi artikkel: Tannberg, T., Tarvel, E. Documents on the Soviet military occupation of Estonia 1940. - Trames, 2006, 10, 1, 81-95. Vt ka Hiio, T. Soviet military preparations in Estonia during the year before Barbarossa. - Northern European overture to war 1939-1941: From Memel to Barbarossa. Ed. by M. H. Clemmesen, M. S. Faulkner. (History of Warfare, 87.) Brill, Leiden, Boston, 2013, 405-432.

142 Paavle, I. Riigivolikogu moodustamine: Marionettriigivolikogu tegevus. - Sõja ja rahu vahel II, 127-163; Sarv, E. Eesti Vabariigi kontinuiteet 1940-1945. - Tõotan ustavaks jääda ...: Eesti Vabariigi Valitsus 1940-1992. Koost ja toim M. Orav, E. Nõu. Eesti Kirjanduse Selts, Tartu, 2004, 15-91.

143 Küüditamine Eestist Venemaale: Juuniküüditamine 1941 ja küüditamised 1940-1953. Koost L. Õispuu. (Represseeritute isikute registrid, 6.) Eesti Represseeritute Registri Büroo, Tallinn, 2001; Poliitilised arreteerimised Eestis, 1. kd: Poliitilised arreteerimised Eestis 1940-1988 (§ 58); 2. kd: Nõukogude okupatsioonivõimu poliitilised arreteerimised Eestis; 3. kd: Nõukogude okupatsioonivõimu poliitilised arreteerimised Eestis 1940-1988. Koost L. Õispuu. (Represseeritud isikute registrid, 1-3.) Eesti Represseeritute Registri Büroo, Tallinn, 1996, 1998, 2005. Vt ka lisanimestikud: kd 8/1 ja 8/2. Eesti Represseeritute Registri Büroo, Tallinn, 2010 ja 2019.

${ }^{144}$ Maripuu. M., Kaasik, P. The deportations of 14 June 1941; Maripuu, M., Kuusik, A. Political arrests and court cases from August 1940 to September 1941. - Estonia 1940-1945, 363-390 ja 319-362.

145 Vt ptk: Terroripoliitika. - Sõja ja rahu vahel II, 412-470.

146 Sõja ja rahu vahel I: Eesti julgeolekupoliitika 1940. aastani; Sõja ja rahu vahel II: Esimene punane aasta; Estonia 1940-1945, 1-410.

147 Monograafiana: Mälksoo, L. Illegal annexation and state continuity: The case of the incorporation of the Baltic states by the USSR: A study of the tension between normativity and power in international law. (Erik Castren Institute monographs on international law and human rights, 3.) Martinus Nijhoff, Leiden, Boston, 2003. Seesama eesti keeles: Mälksoo, L. Nõukogude anneksioon ja riigi järjepidevus: Eesti, Läti ja Leedu staatus rahvusvahelises õiguses 1940. a. - 1991. a. ja pärast 1991. a.: Uurimus pingest normatiivsuse ja võimu vahel rahvusvahelises õiguses. Tartu Ülikooli Kirjastus, Tartu, 2005. 


\section{TEINE MAAILMASÕDA (1939/1941-1945)}

Sõjasündmused Eestis 1941. ja 1944. aastal ning Saksa okupatsioon ja Nõukogude okupatsiooni naasmine on olnud viimasel kahel aastakümnel sadakonna monograafia ja teadusartikli teemaks. Uurimistöö keskmes on olnud kolm avarat valdkonda: eestlaste üksused Saksa ja Soome relvajõududes ning Punaarmees; metsavendlus, vastupanuliikumine ja Otto Tiefi valitsus; kolmandana Nõukogude ja Saksa okupatsioonivõimude massirepressioonid, sealhulgas holokaust. Vähem on uuritud okupatsioonipoliitikat ja sõjategevust ennast, selle uurimiseks nappis veel 2000. aastate algul ka juurdepääsetavaid allikmaterjale. Ajakohane süvitsi minev ülevaade Teisest maailmasõjast Eestis on vaatamata eelnenule ikka veel kirjutamata. Mõneti täidavad lünga kolm võõrkeelset ülevaateteost: Kaarel Piirimäe ja Olaf Mertelsmanni initsiatiivil ilmunud artiklikogumikud ${ }^{148}$ ning koguteos „Estonia 1940-1945“. Teisalt on viimasel kümnendil uurijatele ligipääsetavaks saanud hulk teiste riikide arhiivide allikaid, mis lubavad osa senistest käsitustest aegunuks tunnistada, mistõttu on eestikeelse koguteose viibimisel ka oma positiivne pool.

Eesti sõdurid Teises maailmasõjas. Eestlaste üksuste uurimise üks lähtekohti on olnud küsimus õigustatud võitlusest. Teine maailmasõda oli absoluutse enamiku väekõlblikus vanuses ja tervises eesti meeste jaoks totaalne sõda kas Nõukogude või Saksa või Soome vormis, või ka järgemööda või vaheldumisi ühes või teises või kõigis kolmes. Suur osa meestest, kes olid kandnud Saksa või Soome vormi ja jäid Eestisse, sattus 1940. aastate teisel poolel ja 1950. aastate alguseski „kodumaareeturina“ vangi; Punaarmee veteranid nautisid sovetivõimu kasinaid privileege ja pälvisid mälestusmedaleid. ${ }^{149}$ Eesti iseseisvuse taastamise järel hakati palju laiemalt kui ainult veteraniühingutes arutama, kas kohelda Saksa ja Soome sõjaväes võidelnud mehi vabadusvõitlejatena või mitte. Väideti ka, et enamik Punaarmees sõdinud mehi olid surmaähvardusel mobiliseeritud ja seega samuti ohvrid. See ei saa aga laieneda poliittöötajatele ja hävituspataljonlastele ning oma kodanikukohust täitnud NSV Liidu kodanikest liidueestlastele, kellest suur osa samuti eesti laskurkorpusesse jõudis. Mõnikord käsitatakse aga kõiki Punaarmees võidelnud eestlasi ühetaolise grupina. ${ }^{150}$ Märkimisväärseid vastasseise endiste eesti sõdurite vahel pole olnud. Palju suurem oli teema „laetus“ avalikkuses ja rahvusvaheliselt. Pärast aastatepikkust arutelu tõmbas parlament 2012. aastal küsimusele joone alla. ${ }^{151}$

${ }^{148}$ The Second World War and the Baltic states. Ed. by J. S. Corum, O. Mertelsmann, K. Piirimäe. (Tartu historical studies, 4.) Peter Lang, Frankfurt am Main, 2014; Vom Hitler-Stalin-Pakt bis zu Stalins Tod. Hrsg. v. O. Mertelsmann. Bibliotheca Baltica, Hamburg, 2005.

${ }^{149}$ Vt Miil, M. Vaigistatud kangelased: Suure isamaasõja veteranid Nõukogude Eesti tähtpäevaajakirjanduses 1944-1989. - 200 aastat Napoleoni sõjakäigust Venemaale ja selle mõju Läänemere maadele. (Eesti sõjaajaloo aastaraamat 3 (9).) Eesti sõjamuuseum - kindral Laidoneri muuseum, Tallinna Ülikooli Kirjastus, Tallinn, 2014, 233-278.

${ }^{150} \mathrm{Vt}$ nt Eestlased Vene sõjaväes. 1.-3. Koost Leo Õispuu. (Represseeritud isikute registrid, 9-11.) Eesti Represseeritute Registri Büroo, Tallinn, 2008, 2009, 2011.

${ }^{151}$ Riigikogu avaldus Tunnustuse avaldamine Eesti kodanikele. 14.02.2012. - Riigi Teataja III, 15.02.2012, 2 . 
Iseseisvuse taastamise ajal avasid eestlaste üksuste ajaloo tänapäevase uurimise kaks Toe Nõmme ülevaateartiklit. ${ }^{152}$ Järgmisel kümnendil pöörduti teema juurde tagasi. 1998. aastal asutatud Inimsusevastaste Kuritegude Uurimise Eesti Rahvusvahelise Komisjoni uurimisrühm on alates 2000. aastast Saksa Liiduarhiivi Sõjaarhiivis digikopeerinud tuhandeid lehekülgi Wehrmachti ja Relva-SS-i väejuhatuste ja staapide Eestisse ja eestlaste üksustesse puutuvaid dokumente, mille - aga ka Eesti arhiivides hoitavate dokumentide ja rohke mälestuskirjanduse - baasil valmisid väeüksuste liigiti põhjalikud artiklid. ${ }^{153}$ Lühem kokkuvõte eelnimetatud ja vahepeal lisandunud allikmaterjali põhjal avaldati 2012. aastal Eesti sõjaajaloo aastaraamatus. ${ }^{154}$ Punaarmee eesti üksuste kohta olid Eesti uurijate käeulatuses suuresti ainult laskurkorpuse parteiorganite materjalid, mida säilitati toonases parteiarhiivis (üksuste arhiivid on Vene kaitseministeeriumi keskarhiivis). Nende ning sovetiaegse kirjanduse ja mälestuste põhjal valmisid Peeter Kaasiku artiklid Eesti üksustest Punaarmees ${ }^{155}$ ja eestikeelne ülevaateartikkel. ${ }^{156}$ Varasemad uurimused võttis värskendatud kujul kokku artiklikogumik „Korpusepoisid“. ${ }^{157}$ Eraldi uurimused on avaldatud piirikaitserügementidest, pitkapoistest ja soomepoistest. ${ }^{158}$ Hulga eri kvaliteediga mälestustekogumikke, nimekirju jm on koostanud veteranid

152 Nõmm, T. 22. Eesti territoriaallaskurkorpus aastail 1940-1941. - Eesti Teaduste Akadeemia toimetised. Ühiskonnateadused, 1990, 39, 1, 43-58; Nõmm, T. Eesti üksustest Saksa sõjaväes: formeerimine ja isikkoosseis. - Akadeemia, 1990, 1, 113-137.

${ }^{153}$ Kuusik, A. Estonian Omakaitse in 1941-1944; Hiio, T. Estonian security groups and Eastern battalions in German army in 1941-1944; Niglas A., Hiio, T. Estonian defence battalions / Police battalions in the German armed forces; Hiio, T., Kaasik, P. Estonian units in the Waffen-SS; Niglas A., Hiio, T. Estonian border defence regiments in 1944 ja ka Piirimäe, K. Estonian prisoners of war in Germany after World War II. - Estonia 1940-1945, 797-806; 807-824; 825-876; 927-967; 969-999; 1019-1032.

${ }^{154}$ Hiio, T. Eesti üksustest Wehrmacht'i, SSi ja politsei ning Relva-SSi alluvuses Teise maailmasõja ajal: Komplekteerimisest ja formeerimisest. - Väeteenistusest Eestis ja eestlastest väeteenistuses, 158-265; vt ka Hiio, T. Estnische Einheiten der Waffen-SS: Vorgeschichte, Rekrutierung, Zusammensetzung. - Die Waffen-SS: Neue Forschungen. Hrsg. v. J.-E. Schulte, P. Lieb, B. Wegner. (Krieg in der Geschichte, 74.) Schöningh, Paderborn, 2014, 139-159.

${ }^{155}$ Kaasik, P. Disbanding of the Estonian army and military establishments; Formation of the Estonian army into the Red army rifle corps; The 8th Estonian rifle corps in northwestern Russia in 1942 1944. - Estonia 1940-1945, 143-162; 769-796; 909-926; Kaasik, P. Estonian national units in the Soviet army. - Estonia since 1944, 83-94.

${ }^{156}$ Kaasik, P. Eesti rahvusväeosade formeerimisest Nõukogude armee koosseisus aastatel 1940-1956. - Väeteenistusest Eestis ja eestlastest väeteenistuses, 102-151.

${ }^{157}$ Korpusepoisid: Eesti sõjamehed 22. eesti territoriaalkorpuses ja 8. eesti laskurkorpuses Teises maailmasõjas aastatel 1940-1945. Koost H. Ojalo. Eesti Akadeemiline Sõjaajaloo Selts, Sentinel, Tallinn, 2007.

${ }^{158}$ Eesti piirikaitserügemendid ja politseipataljonid Narva rindel 1944. aastal. Koost M. Nisuma. (Eesti Sõjamuuseumi - Kindral Laidoneri Muuseumi toimetised, 8.) Varrak, Tallinn, 2011; Laar, M., Pillak, P., Rebas, H., Saueauk, M. Soomepoisid: võitlus jätkub: II maailmasõjas Soome armees võidelnud Eesti vabatahtlike ajalugu 1939-2010. Grenader, Tallinn, 2010; Löögiüksus „Admiral Pitka“. 22. septembril 2006 peetud ajalookonverentsi „Tallinna kaitsjad 22. septembril 1944“ ettekanded. Idee V. Salo, koost T. Hiio. (Eesti Sõjamuuseumi - Kindral Laidoneri Muuseumi toimetised, 4.) Eesti sõjamuuseum - kindral Laidoneri Muuseum, Viimsi, 2008; Mandel, M. Pitka ja pitkapoisid - legendid või tõelisus? Eesti Ajaloomuuseum, Tallinn, 2012. 
ise, asjaarmastajad ja kollektsionäärid. ${ }^{159}$ Koguteos eesti üksustest Teises maailmasõjas on valmimas S-Keskuse sarjas „Sõja ja rahu vahel“.

Suvesõda Eestis 1941. aastal on eraldi teema. Kitsamas tähenduses nimetatakse suvesõjaks mitte Nõukogude-Saksa sõda Eesti territooriumil juulist oktoobrini, vaid eesti metsavendade, omakaitselaste ja Saksa regulaarüksuste alluvuses eesti vabatahtlikest moodustatud rekke- jm üksuste võitlust NKVD hävituspataljonide ja väiksemate Punaarmee üksustega. Suvesõja kontseptsioon oli tähtis nii paguluses kui ka pärast iseseisvuse taastamist näitamaks, et eestlased olid võimaluse tekkimisel valmis relvavõitluseks, et oma iseseisvus tagasi võita. ${ }^{160}$ Lugejal aga võis tekkida arusaamine, et metsavennad ja omakaitselased ajasidki Punaarmee oma jõul Eestist välja. Uuemad uurimused on jõudnud tasakaalukamate järeldusteni. ${ }^{161}$ Suvesõja uurimise põhiallikaks olid pikka aega Omakaitse aruanded 1941. aasta suvel toimunust, mille põhjal avaldati Eesti vabastamisele pühendatud artikleid juba Saksa okupatsiooni ajal. Hiljem olid need detailitäpsed artiklid ja aruanded ise tänuväärne allikas uurimistöös „nõukogudevastase elemendi“ väljaselgitamiseks. Sõjaajaloo uurija rõõmuks on säilinud ka vastaspoole samatüübiline materjal, NKVD hävituspataljonides võidelnud meeste ja naiste 1942. aastal Nõukogude tagalas kogutud mälestused või õieti debriifingu üleskirjutused. ${ }^{162}$ Need publitseeris maakondade kaupa Mart Arold. ${ }^{163}$ Hävituspataljonide tegevust 1941. aastal on eraldi uurinud Peeter Kaasik ja Indrek Paavle. ${ }^{164}$ Laiema pildi 1941. aasta sõjategevusest pakub Eesti sõjamuuseumi ja S-Keskuse 2006. aasta oktoobris sõjategevuse alguse 65. aastapäeva puhul peetud konverentsi ettekannete kogumik ja mõned artiklid. ${ }^{165}$

${ }^{159}$ Vt nt: Visadus võitis: Pataljon „Narva“ ajalugu III. Koost H. Tulp, toim E. Vääri. Klubi „WikingNarva“, Tartu, 1999); Eesti idapataljonid idarindel 1941-1944. Toim A. Adamson. Eesti Idapataljonide Võitlejate Klubi, Argo TTP, Tallinn, 2004; Eesti diviisi struktuur ja ohvitseride koosseis II maailmasõjas. Koost L. Tammiksaar. Eesti Riigikaitse Akadeemia Kirjastus, Tallinn, 1998; Lühike ülevaade mõningatest Eesti üksustest Wehrmachtis, politseis ja SS-is. Koost L. Tammiksaar. L. Tammiksaar, Tallinn, 2001.

${ }^{160}$ Vt Lindmäe, H. Suvesõda 1-9: Suvesõda Tartumaal 1941; Suvesõda Virumaal 1941; Suvesõda Viljandimaal 1941; Suvesõda Pärnumaal 1941; Suvesõda Valgamaal 1941; Suvesõda Järvamaal 1941; Suvesõda Võrumaal 1941; Suvesõda Petserimaal 1941; Suvesõda Harjumaal 1941. 1. ja 5. köite väljaandja H. Lindmäe, 2. ja 3. köite väljaandja Okupatsioonide Repressiivpoliitika Uurimise Riiklik Komisjon, 4. ja 6.-9. köite väljaandja Sihtasutus Valge Raamat, Tartu, 1999, 2002, 2004, 2006, 2008, 2010, 2012, 2013, 2015.

${ }^{161}$ Metsavennad Suvesõjas 1941: Eesti relvastatud vastupanuliikumine Omakaitse dokumentides. Koost T. Noormets. (Ad fontes, 13.) Riigiarhiiv, Tallinn, 2003.

${ }^{162}$ Vt Kaasik, P. 1942. aastal Nõukogude Liidu tagalas kogutud mälestused-tunnistused ajalooallikana. - Tuna, 2020, 1, 79-98. (Debriifing - infokogumismeetod, mis tähendab omade ärakuulamist ja nende käest info kogumist, http://termin.eki.ee/militerm, 31.07.2020.)

${ }^{163}$ Sortside saladused. I-XII. Koost M. Arold. Tungal, Tartu, 1993-2001. (I-III koostaja pseudonüümi L. Levala all; V-X pealkiri „Sortside saladusi“.)

${ }^{164}$ Kaasik, P., Paavle, I. Destruction battalions in Estonia in 1941. - Estonia 1940-1945, 469-494; Kaasik, P. Hävituspataljonidest Eestis 1941. aasta sõjasuvel. - Ajalooline Ajakiri, 2019, 1 (167), $3-36$.

165 1941. aasta Eestis. (Eesti Sõjamuuseumi - Kindral Laidoneri Muuseumi aastaraamat, 6.) Eesti sõjamuuseum - kindral Laidoneri muuseum, SE\&JS, Tallinn, 2007); Hiio, T. Combat in Estonia in 1941. - Estonia 1940-1945, 413-430 ja Hiio, T. II maailmasõda ja Viljandimaa: sõjalised 
Eraldi uurimisteema on 1941. aasta mobilisatsioon Punaarmeesse, ${ }^{166}$ mobiliseeritud meeste massiline hukkumine tööpataljonides ja ellujäänutest 8. eesti laskurkorpuse komplekteerimine. ${ }^{167}$

Saksa okupatsiooni aja üksikküsimusi alates majandusest ja massirepressioonidest ${ }^{168}$ kuni kultuurielu ja ülikoolini on eritletud paljudes artiklites, peatükkides ja uurimustes. Okupatsioonivõimu korraldusest kaitses doktoritöö Meelis Maripuu. ${ }^{169}$ Märkimist väärib ka tema artikkel Patarei vanglast. ${ }^{170}$ Repressioone Saksa okupatsiooni ajal uuriti sovetiajal riiklik-propagandistlikel eesmärkidel ja nendest eesmärkidest tuleneva põhjalikkusega. ${ }^{171}$ Pärast Eesti iseseisvuse taastamist keskendus tähelepanu esialgu Nõukogude repressioonidele, kuid nüüdseks on olemas Indrek Paavle nimekiri koos lühibiograafiatega Saksa okupatsiooni ajal hukatute, mõrvatute ja osaliselt ka vanglates surnute kohta; ${ }^{172}$ selle koostamist holokaustiohvrite osas alustasid Eugenia Gurin-Loov ja Viktor Boikov 1990. aastate alguses. ${ }^{173}$ Andmed Saksa okupatsiooni ajal Eestist Saksamaale ja mujale koonduslaagrisse saadetute kohta on lünklikud, ${ }^{174}$ nagu ka Nõukogude sõjavangide kohta Eestis. ${ }^{175}$ Põhjalik ülevaade on see-eest olemas Saksa ja Eesti julgeolekuasutustest. ${ }^{176}$

Holokausti ajalugu Eestis. Alates 1990. aastate lõpust sai märkimisväärseks osaks Saksa okupatsiooniaja uurimisest holokausti ajalugu. Selle kohta on hulk uurimusi peamiselt Meelis Maripuu ja Riho Västriku sulest. ${ }^{177}$ Mõrvatud juutide

operatsioonid ja üksused, sõjaväevalitsus ja asutused. - Viljandi Muuseumi toimetised II. Toim A.-A. Vislapuu. Viljandi Muuseum, Viljandi, 2011, 171-208.

${ }^{166}$ Noormets, T. Mobilisatsioon Punaarmeesse Eestis 1941. a. - Laidoneri Muuseumi aastaraamat, 2. Kindral Laidoneri Muuseum, SE\&JS, Tallinn, 2003, 27-51; Noormets, T. Mobilisation into the Red army in Estonia in 1941. - Estonia 1940-1945, 431-444.

${ }^{167}$ Kaasik, P. Formation of the Estonian rifle corps in 1941-1942. - Estonia 1940-1945, 885-908.

${ }^{168}$ Niinepuu, S. Eesti Põlevkivi ja Saksamaa - sügis 1941 kuni sügis 1944: Magistritöö. Tartu Ülikool, Filosoofiateaduskond, Ajaloo ja arheoloogia instituut, 2011; Nurmis, K. Between aspiration and adaptation: German war propaganda in occupied Estonia from 1941 till 1942. - The Second World War and the Baltic states, 223-248; Maripuu, M. Soviet prisoners of war in Estonia 1941-1944. - Estonia 1940-1945, 739-768.

${ }^{169}$ Maripuu, M. Omavalitsuseta omavalitsused: halduskorraldus Eestis Saksa okupatsiooni ajal 19411944. (Dissertationes historiae Universitatis Tartuensis, 26.) Tartu Ülikooli Kirjastus, Tartu, 2012.

${ }^{170}$ Maripuu, M. Patarei vangla. - Euroopa pärast I maailmasõda: Rahvusriikide armeede sünd impeeriumide varemetel, 240-271.

${ }^{171}$ Selle kohta vt: Maripuu, M. Külma sõja aegsed näidiskohtuprotsessid Eesti NSV-s: õigus ja propaganda kaalukausil. - Nõukogude Eesti külma sõja ajal, 88-140.

172 Eesti rahvastikukaotused, II/1: Saksa okupatsioon 1941-1944: hukatud ja vangistuses hukkunud.

${ }^{173}$ Gurin-Loov, E. Eesti juutide katastroof 1941. Eesti Juudi Kogukond, Tallinn, 1994.

${ }^{174} \mathrm{Vt}$ andmekogu „Rahvuskaaslased Saksa koonduslaagrites“: http://mnemosyne.ee/old/rahvuskaaslased-saksa-koonduslaagrites/ (31.07.2020).

${ }^{175}$ Maripuu, M. Soviet prisoners of war in Estonia 1941-1944.

${ }^{176}$ Kuusik, A. Court system in Estonia in 1941-1944; German police institutions in 1941-1944; Security police and SD in Estonia in 1941-1944; German Order Police in Estonia; Estonian constabulary in 1941-1944; Secret field police of the Wehrmacht in Estonia in 1941-1944. - Estonia 1940-1945, 569-612.

${ }^{177}$ Maripuu, M. Execution of Estonian Jews in local detention institutions in 1941-1942; Places of imprisonment subordinated to the chief of the security police and SD in Estonia; Annihilation of Czech and German Jews in Estonia in 1942-1943; French Jews at the Tallinn AEL. - Estonia 1940-1945, 
nimekiri sisaldub eelmises lõigus mainitud Indrek Paavle koostatud raamatus. Holokaustist Eestis on Anton Weiss-Wendt kaitsnud USA-s doktoriväitekirja. ${ }^{178}$

1944. aasta on kaetud rohkete uurimustega. Mitmele sündmusele omistatud tähendus Eesti ajaloolisele identiteedile on saanud suuremaks kui see on tavalisel ajaloosündmusel: 1944. aasta mobilisatsioon ja õigusliku järjepidevuse kandja, viimase peaministri Jüri Uluotsa toetus sellele, Tallinna pommitamine märtsis, ${ }^{179}$ rahvuslaste arreteerimine julgeolekupolitsei ja SD poolt aprillis ja mais, lahingud Sinimägedes juuli lõpus ja augusti esimesel nädalal, soomepoiste tagasitulek ja kontradmiral Johan Pitka löögiüksuse moodustamine augustis, massimõrv Klooga koonduslaagris septembris, Emajõe, Avinurme ja Porkuni lahing eesti üksustega mõlemal poolel, Otto Tiefi valitsuse moodustamine Tallinnas samuti septembris, suur põgenemine üle mere Rootsi ${ }^{180}$ ning lahingud saartel, sh Punaarmee eesti laskurkorpuse lahingud Saaremaal oktoobris ja novembris. ${ }^{181}$ Vähem on kirjutatud mobilisatsioonist Punaarmeesse aasta lõpus ja 1945. aasta alguses; võrreldes sovetiajaga räägitakse palju vähem ka eesti laskurkorpuse lahingutest Eestis ja Kuramaal. ${ }^{182}$ Nagu 1941. aasta puhulgi on väljaspool eestlaste tegemisi vähem tähelepanu pälvinud sõda ise regulaararmeede lahingud Eesti pinnal ning Saksa vägede ja asutuste, aga ka poliitvangide ja juudi vangide evakueerimine Eestist. ${ }^{183}$

Eesti keeles ilmunust väärivad 1944. aasta kontekstis tiitlit „Standardwerk“kaks teost: Enn Nõu ja Mart Orava koostatud koguteos Eesti Vabariigi Rahvuskomiteest, Otto Tiefi valitsusest, eksiilvalitsusest ja õiguslikust järjepidevusest ning Mart Laari tetraloogia 1944. aasta sõjast Eestis. ${ }^{184}$ Väga palju väideldud küsimusele langenute arvust 1944. aasta Sinimägede lahingus vastas sine ira et studio Reigo Rosenthali ja tema kaastööliste 2015. aastal ilmunud artikkel. ${ }^{185}$

651-662; 681-688; 705-716; 717-718; Maripuu, M., Västrik, R. Vaivara concentration camp in 1943-1944. - Estonia 1940-1945, 719-738; Västrik, R. Tartu concentration camp in 1941-1944. Samas, 689-704; Västrik, R. Klooga koonduslaager - Vaivara süsteemi koletu lõpp. - Vikerkaar, 2001, 8, 147-155; Västrik, R. Tartu koonduslaager. - Ajalooline Ajakiri, 1999, 3/4 (106/107), 71-80.

${ }^{178}$ Weiss-Wendt, A. Murder without hatred: Estonians and the Holocaust. Syracuse University Press, Syracuse, 2009.

179 Tallinn tules: Dokumente ja materjale Tallinna pommitamisest 9./10. märtsil 1944. Koost J. Kivimäe, L. Kõiv. (Tallinna Linnaarhiivi toimetised, 2.) Tallinna Linnaarhiiv, Tallinn, 1997; sõjalisest vaatepunktist: Liias, T. Tallinna õhutõrje 1944. aasta märtsipommitamise ajal. - Akadeemia, 2010, 3, 417-435.

${ }^{180}$ Vt nt Kumer-Haukanõmm, Kaja. Teise maailmasõja aegne eestlaste sundmigratsioon Läände. Acta historica Tallinnensia, 2011, 17, 95-109; 1944. aasta suur põgenemine ja eliidi lahkumine Eestist. - Tuna, 2014, 4, 50-56.

${ }^{181}$ Siiski: Kaasik, P. Eesti rahvusväeosade formeerimisest, 133-136.

${ }^{182}$ Kaasik, P. The 8th Estonian rifle corps in the conquest of Estonia in 1944, in Courland and from summer 1945 in Estonia. - Estonia 1940-1945, 1001-1018.

183 Maripuu, M. Tallinna evakueerimine 1944. a septembris. - Löögiüksus „Admiral Pitka“, 38-53; Hiio, T. Combat in Estonia in 1944. - Estonia 1940-1945, 1035-1094.

184 Tõotan ustavaks jääda ...; Laar, M. Emajõgi 1944: II maailmasõja lahingud Lõuna-Eestis. 2. tr. Varrak, Tallinn, 2005; Laar, M. September 1944: Otto Tiefi valitsus. Varrak, Tallinn, 2012; Laar, M. Sinimäed 1944: II maailmasõja lahingud Kirde-Eestis. 3. tr. Varrak, Tallinn, 2007; Laar, M. Saaremaa 1944: Eesti Laskurkorpuse kannatuste rada. Varrak, Tallinn, 2010.

${ }^{185}$ Astafjev, A., Kütt, A., Rosenthal, R. Vastaspoolte inimkaotustest Narva rindel 1944. aasta 24. juulist kuni 7. augustini (Narva ja Sinimägede lahingud). - Tuna, 2015, 4, 67-73. 


\section{NÕUKOGUDE AEG (1944-1991)}

1990. aastate teisel poolel, pärast S-Keskuse asutamist, peeti seminare ja konverentse, millel arutati võimalikke ja vajalikke uurimisteemasid, juurdepääsu arhiivimaterjalidele jm. Ettekanded ja arutelude tulemused avaldati kahes artiklikogumikus. ${ }^{186} \mathrm{Pilt}$ sellest, mida on vaja uurida, oli üldjoontes selge. Mida tegelikult uuritakse, selle on 20. sajandi teise poole ajalukku puutuvalt enamasti määranud (ühiskondlik) tellimus ja uurimisprojektide rahastus. Sovetiaja kogemuse ja vene keele oskusega uurijaidki, rääkimata noorema põlvkonna ajaloolastest, on pelutanud partei- ja valitsusdokumentide tohutu hulk ning nende sovetismidest kubisev keel. Niisiis on suur osa uurimistööst veel tegemata.

1990. aastatel alustati massirepressioonide ja Nõukogude julgeolekuasutuste tegevuse uurimisega ja töö jätkub siiani. Selle sajandi esimesel kümnendil liitus külma sõja ajalugu Eestis. Sovetiaja vastu tunnevad oma vaatenurgast huvi poliitika- ja sotsiaalteadlased, demograafid, etnoloogid ja kunstiajaloolased, kes on kaitsnud väitekirju ja avaldanud monograafiaid.

Sõjajärgsete massirepressioonide ohvrite väljaselgitamist alustas 1980. ja 1990. aastate vahetusel Memento Eesti Represseeritute Registri Büroo. ${ }^{187}$ Paralleelselt uurisid 1949. aasta küüditamist Herbert Ligi ja Aigi Rahi-Tamm, kes kaitses sõjajärgsetest massirepressioonidest oma doktoritöö. ${ }^{188}$ 1945., 1949., 1950. ja 1951. aasta küüditamise ohvrid on nüüdseks tuvastatud, nagu ka absoluutne enamus pärast sõda arreteeritutest ja Gulagi vangilaagritesse saadetutest. Vähem on teada riiginormide mittetäitmise eest vangistatud talunike saatusest. ${ }^{189}$ 2019. aastal tõlgiti ja publitseeriti MGB 1949. aasta Eesti küüditamisoperatsiooni toimik ja avaldati mitu uurimust selle kohta. ${ }^{190}$ Sõjajärgsetest küüditamistest Eestis, eriti 1949. aasta märtsiküüditamisest, on kirjutatud palju. ${ }^{191}$

${ }^{186}$ Rajaotsingud (vt viide 2); Ajaloolise tõe otsinguil: 20. jaanuaril 1999 Tallinnas toimunud konverentsi „Eesti lähiajaloo allikakriitilisi probleeme“ materjalid. Kistler-Ritso Eesti Sihtasutus, MTÜ S-Keskus, Rahvusarhiiv, Tallinn, 1999.

${ }^{187}$ Küüditatute nimekirju vt: Küüditamine Eestist Venemaale: Märtsiküüditamine 1949, 2. osa; Küüditamine Eestist Venemaale: Juuniküüditamine 1941 ja küüditamised 1940-1953, 773-881. Koost L. Õispuu. (Represseeritute isikute registrid, 5; 6.) Eesti Represseeritute Registri Büroo, Tallinn, 1999; 2001.

${ }^{188}$ Rahi-Tamm, A. Teise maailmasõja järgsed massirepressioonid Eestis: Allikad ja uurimisseis. (Dissertationes historiae Universitatis Tartuensis, 9.) Tartu Ülikooli Kirjastus, Tartu, 2004.

${ }^{189}$ Selle kohta vt: Paavle, I. Sovietisation of agriculture. - Estonia since 1944, 37-78; Paavle, I. Vili ja munad režiimi teenistuses: Sundandam 1940. aastate Eesti külas. - Eesti ajaloost nõukogude võimu perioodil. Koost T. Tannberg. Ajalooline Ajakiri, 2009, 1/2 (127/128), 213-229.

190 Toimik „Priboi“: Artikleid ja dokumente 1949. aasta märtsiküüditamisest. Koost M. Saueauk, M. Maripuu. (Eesti Mälu Instituudi toimetised, 2.) Tartu Ülikooli Kirjastus, Tartu, 2019.

${ }^{191}$ Saueauk, M., Tannberg, T. Kuidas võeti Kremlis vastu otsus ühise küüditamisoperatsiooni läbiviimiseks Balti liiduvabariikides 1949. aasta kevadel? Nikolai Karotamme ülestähendus kohtumisest Jossif Staliniga 18. jaanuaril 1949. - Tuna, 2014, 3, 92-97; Rahi-Tamm, A., Kahar, A. The Deportation Operation „Priboi“ in 1949; Rahi-Tamm, A. Deportation of individuals of German nationality from Estonia in 1945. - Estonia since 1944, 429-460; 415-428; Uuemaid aspekte märtsiküüditamise uurimisest. Toim O. Liivik. (Varia Historica, 4.) Eesti Ajaloomuuseum, Tallinn, 2009; Allikmaterjale 1949. aasta märtsiküüditamisest. I-XI. Koost V. Ohmann ja T. Tannberg. - Akadeemia, 2009, 3 - 2010, 1. 
Pärast Teise maailmasõja lõppu vangistati Eestis poliitilistel põhjustel üle 30000 inimese, keda oli märgatavalt rohkem kui küüditatuid. Nende saatus on jäänud küüdituse ohvrite saatuse varju. Pigem on uuritud vangistamiseni viinud (relvastatud) vastupanuliikumise eri aspekte ja episoode, ennekõike metsavendlust. Kokkuvõtlikud ülevaated sõjajärgsest vangistamisest poliitilistel põhjustel avaldas Meelis Saueauk. ${ }^{192}$ Aivar Niglas on uurinud ellujäänud repressiooniohvrite vabastamist pärast Stalini surma ja analüüsinud võimalusi massirepressioonide süstematiseerimiseks. ${ }^{193}$

Pärast Nõukogude okupatsiooni jätkumist käis Eestist läbi kümneid tuhandeid sõjavange ning peamiselt Saksamaalt ja Austriast repatrieeritud inimesi, keda hoiti spetsiaalsetes laagrites. Mõlema kategooria hulgas oli ka eestlasi. Eestlasi, lätlasi ja leedulasi, kes olid Saksa vormis Punaarmee kätte langenud ja algul üle kogu NSV Liidu lääneosa ja Punaarmee poolt vabastatud/okupeeritud alade sõjavangilaagritesse laiali puistatud, rakendati alates 1946. aasta esimesest poolest sõjaväe- või siseministeeriumi objektide ehitusel Eestis, eeskätt Paldiskis ja Sillamäel, ${ }^{194}$ aga ka Tallinnas. Saksa sõjavangidest Eestis räägib Peeter Kaasiku doktoriväitekiri. Ta on uurinud ka repatrieeritute saatust kontroll-filterlaagrites, „kodumaareeturite“ erikontingenti jm ${ }^{195}$ ning ka laagrite ja vanglate süsteemi Eesti alal üldisemalt. ${ }^{196}$ Repatrieerimist on eraldi uurimuses käsitlenud Karin Kumer-Haukanõmm. ${ }^{197}$ Peeter Kaasiku artikkel psühhiaatrilise sundravi kasutamisest poliitvangide peal ulatub Stalini surma järgsesse aega. ${ }^{198}$ Indrek Paavle uuris 1941. aastal katkenud repres-

${ }^{192}$ Saueauk, M. Mass repressions in Estonia during the late Stalinist period; Data about the persons arrested in Estonia during the Soviet political repressions in 1942-1990. - Estonia since 1944, 311-320; 307-310.

${ }^{193}$ Niglas, A. Release ahead of time of Estonian citizens and residents repressed for political seasons by the Soviet authorities and their rehabilitation from 1953 to the 1960s. - Estonia since 1944, 461-489; Niglas, A., Maripuu, M. „NSV Liidu valitsuse määruseid ei väljastata isegi NSV Liidu Ülemkohtule“: 1941. aasta küüditamisoperatsiooni alusakti võltsimisest Jossif Stalini aegsete repressioonisotsuste revideerimise käigus 1960. aastatel. - Juridica, 2019, 1, 69-75; Niglas, A. Küüditatute vabastamine ja nende asumisele saatmise otsuste tühistamine Jossif Stalini surma järel. Toimik „Priboi“, 135-171.

194 Viimase kohta vt ka: Maremäe, E. Sillamäe uraanitehaste asutamine ja töö aastatel 1946-1952 (1973): Eesti diktüoneemakilda kasutamine. - Akadeemia, 2000, 3, 476-512.

${ }^{195}$ Kaasik, P. Nõukogude Liidu sõjavangipoliitika Teise maailmasõja ajal ja sõjajärgsetel aastatel: Sõjavangide kinnipidamissüsteem Eesti näitel ja hinnang sõjavangide kohtlemisele rahvusvahelise õiguse järgi. (Tallinna Ülikooli humanitaarteaduste dissertatsioonid, 29.) Tallinna Ülikool, Tallinn, 2012; Kaasik, P. Construction battalions in Estonian territory 1944-1950; USSR People's Commissariat for Internal Affairs control-filtration camp no. 0316; Prisoners of war of Estonian origin as Soviet prisoners of war; Special contingent - "Traitors to the Homeland". - Estonia since 1944, 507-540, 403-506; 345-358; 333-344. Eestikeelne ülevaateartikkel: Kaasik, P. Erikontingendi filtreerimine ja töölerakendamine Eesti NSV-s kontroll-filterlaager nr 0316 näitel. - Tuna, 2010, 4, 24-36.

${ }^{196}$ Kaasik, P. Prisons in Estonia 1944-1955; Estonian SSR NKVD/MVD correctional labour detention centres in 1944-1956. - Estonia 1940-1945, 541-566; 567-590.

${ }^{197}$ Kumer-Haukanõmm, K. The Yalta agreement and the repatriation of Estonians in 1945-52. The Baltic states under Stalinist rule. Ed. by O. Mertelsmann. (Das Baltikum in Geschichte und Gegenwart, 4.) Böhlau, Köln, 2016, 225-245.

${ }^{198}$ Kaasik, P. Misapplication of enforced psychiatric treatment in the Soviet Union: A few examples from Estonia. - Sovietisation and violence: The case of Estonia. (Eesti Mälu Instituudi toimetised, 1.) Tartu Ülikooli Kirjastus, Tartu, 2018, 59-109. (Parandatud ja täiendatud versioon artiklist 
sioonide jätkamist Eesti poliitilise eliidi nende liikmete vastu, kes olid 1941. aastal repressioonidest pääsenud, kuid 1944. aastal Eestisse jäänud. Tema uuritud teised ohvrikategooriad on rahvuslased ning Saksa okupatsioonivõimu asutustes teeninud mehed ja naised. 199

Metsavendluse teema on olnud populaarseim - laiemas käsitluses on metsavendlus kangelaslugu relvastatud vastupanust, paralleelne 1949. aasta küüditamise ohvrilooga, ning sellisena kõnetab ta avalikkust. Metsavendade endi loodud dokumente oligi vähe ja veel vähem on neid säilinud. Metsavendluse uurimine põhineb peamiselt Nõukogude julgeolekuasutuste materjalidel, arreteeritute juurdlustoimikutel ning mälestustel ja intervjuudel endiste metsavendadega. Metsavendlust uurivad ka sõjandusspetsialistid ja arheoloogid. ${ }^{200}$ Kõigepealt väärivad märkimist kaks allikapublikatsiooni, „Eesti metsavennad 1944-1957“ ja „Hävitajad“, mille sissejuhatavad artiklid on omaette uurimused. ${ }^{201}$ Viimane käsitleb nn Nõukogude aktiivi liikmetest kohtadel moodustatud hävituspataljone. Pearu Kuusk kaitses 2005. aastal magistritöö ENSV siseministeeriumi banditismivastase võitluse osakonnast, töö ilmus ka raamatuna. ENSV SM BVVO oli üks mitmest asutusest, mis sõjajärgsetel aastatel metsavendadevastase võitlusega tegeles. ${ }^{202}$ Mati Mandel on kirjutanud uurimuse kuulsast Pärnu- ja Läänemaa metsavennast Ants Kaljurannast. ${ }^{203}$ Metsavendlus ja vastupanuliikumine olid ajakirja Tuna algaastatel paljude artiklite teemaks. Enamasti põhinesid need käsitlused mõni aasta varem uurijatele avanenud julgeolekutoimikutel. ${ }^{204}$ Metsavendlusest laiemas vaates on kirjutanud Tõnu Tannberg, ${ }^{205}$ langenud metsavendade nimekirja koostas Eerik-Niiles Kross. ${ }^{206}$ Nõukogude

Kaasik, P. Psühhiaatrilise sundravi kuritarvitamisest Nõukogude Liidus. - Tuna, 2011, 4, 79-96.

${ }^{199}$ Paavle, I. Repression of the political elite of the Republic of Estonia in 1944-1953; Repressions by Soviet security agencies against underground Estonian national opposition operating during German occupation; Repressions of officials of the Estonian Self-Administration (1941-1944) and of municipal and rural municipal governments during the post-war years. - Estonia since 1944, 359-376; 377-390; 391-404.

${ }^{200}$ Kiudsoo, M., Andreller M., Kuusk, P. Preliminary results of archaeological investigations of the bunker of the forest brothers in Harju county. - Archaelogical Fieldwork in Estonia = Arheoloogilised välitööd Eestis 2014. Tallinn, 2015, 211-214.

${ }^{201}$ Eesti metsavennad 1944-1957: Dokumentide kogumik. Koost Tiit Noormets. (Ad fontes, 18.) Rahvusarhiiv, Tartu, 2014; Hävitajad: Nõukogude hävituspataljonid Eestis 1944-1954: Dokumentide kogumik. Koost T. Noormets, V. Ohmann. (Ad fontes, 15.) Riigiarhiiv, Tallinn, 2015.

${ }^{202}$ Kuusk, P. Nõukogude võimu lahingud Eesti vastupanuliikumisega: Banditismivastase Võitluse Osakond aastatel 1944-1947. Tartu Ülikooli Kirjastus, Tartu, 2007.

${ }^{203}$ Mandel, M. Kogu tõde Hirmus-Antsust? Eesti Ajaloomuuseum, Tallinn, 2010.

${ }^{204}$ Nt Ritson, T. Toomas Hellat ja KGB. [I]-VIII. - Tuna, 1998, 1 - 2000, 4; Pihlau, J. Vendade Saalistete lugu: 50 aastat saatuslikust punkrilahingust Eidapere metsas. - Tuna, 1999, 4, 48-55; Pihlau, J. Raadiomängud Eestis Teise maailmasõja ajal ja järel. [I]-VIII. - Tuna, 2008, 2 - 2010, 3.

${ }^{205}$ Tannberg, T. Julgeolekuorganite tegevusest metsavendluse mahasurumisel 1953. aasta esimestel kuudel. - Akadeemia, 2005, 3, 554-572; Tannberg, T. Wie bekämpft man die Waldbrüder? Die baltische Frage im Kreml Ende 1944. - Forschungen zur baltischen Geschichte, 2009, 4, 190-209; Tannberg, T. „Kas Lavrenti Pavlovitš Beria - poliitbüroo liige - ei olegi siis partei?“: Ääremärkusi L. Beria „uuele kursile" vastupanuliikumise mahasurumisel 1953. aasta kevadel. - Tuna, 2005, 4, 52-69.

${ }^{206}$ Pro Patria II: Auraamat langenud ja hukkunud metsavendadele 1944-1978: (lühinimestik): tööversioon. Koost E.-N. Kross. (ORURK, 13.) Okupatsioonide Repressiivpoliitika Uurimise Riiklik Komisjon, Tartu, 1998. 
julgeolekuasutuste tegevust Eestis 1940. aastatel ja 1950. aastate alguses uurisid Jaak Pihlau, ${ }^{207}$ Meelis Saueauk jt. ${ }^{208}$ Saueaugu doktoritöö käsitles julgeolekuorganite ja kommunistliku partei alluvusvahekorda ja koostööd Eesti sovetiseerimisel. ${ }^{209}$

Ajakohast üldkäsitlust Nõukogude ajast Eestis Stalinist ja Karotammest kuni Gorbatšovi ja Väljaseni seni veel ei ole. Osa lünki täidavad Ajaloolise Ajakirja ja Eesti Ajalooarhiivi toimetiste Tõnu Tannbergi koostatud erinumbrid. Esimene on Nõukogude ajast avaldanud kolm erinumbrit, ajalooarhiivi toimetiste sarjas on neid ilmunud kaks. ${ }^{210}$ Tõnu Tannbergilt on ilmunud ka monograafia keskvõimu poliitika kohta Balti riikides sõjajärgsetel aastatel. ${ }^{211} 2015$. aastal avaldatud artiklikogumiku „Behind the iron curtain“ artiklid põhinevad varem eesti keeles ilmunud käsitlustel. $^{212}$

Relvastamata vastupanuliikumise - mida sageli on nimetatud dissidentluseks (selle termini kasutamist Eesti kontekstis on vaidlustatud) - ajaloost on ilmunud Viktor Niitsoo monograafia ja Arvo Pesti allikapublikatsioon. Mõlema autor-koostaja oli vastupanuliikumisest osavõtnu. ${ }^{213}$ Jaak Pihlau on uurinud vastupanuliikumise kontakte Läänega. ${ }^{214}$ Dissidentlusega piirnev ja sellega osaliselt põimunud teema on Tartu ülikooli sotsioloogialaboratooriumi tegevus ja selle sulgemine 1975. aastal. ${ }^{215}$ 1968. aasta sündmusi Tartus on käsitlenud Eleri Vako (Pihlapuu), 1960.1990. aastaid komsomolis ja parteis uurinud sündmuste osaline Toomas Alatalu. ${ }^{216}$

${ }^{207}$ Pihlau, J. Lehekülgi Eesti lähiajaloost: kuidas loodi ENSV MN juures asuv Riikliku Julgeoleku Komitee. - Akadeemia, 3, 2001, 459-477.

${ }^{208}$ Saueauk, M. Nõukogude julgeolekuorganid Eestis 1944-1953: ülesanded, struktuur, juhtimine. Eesti ajaloost nõukogude võimu perioodil, 77-121. Vt ka Saueauk, M. Use of violence in the investigation of political charges 1944-1953. - Estonia since 1944, 321-332.

${ }^{209}$ Raamatuna: Saueauk, M. Propaganda ja terror: Nõukogude julgeolekuorganid ja Eestimaa Kommunistlik Partei Eesti sovetiseerimisel 1944-1953. SE\&JS, Tallinn, 2015.

${ }^{210}$ Eesti ajaloost nõukogude võimu perioodil. Koost T. Tannbrg, Ajalooline Ajakiri, 2009, 1/2 (127/128); Nomenklatuurisüsteem Eesti NSV-s. Koost T. Tannberg. Ajalooline Ajakiri, 2015, 4 (154); Tsensuur ja propaganda Nõukogude Eestis. - Ajalooline Ajakiri, 4 (166) 2018; Eesti NSV aastatel 1940-1953: Sovetiseerimise mehhanismid ja tagajärjed Nõukogude Liidus. Koost T. Tannberg. Eesti Ajalooarhiivi toimetised, 2007, 15 (22); Ida-Euroopa arengute kontekstis; Nõukogude Eesti külma sõja ajal. Koost T. Tannberg. Eesti Ajalooarhiivi toimetised, 2015, 23 (30).

211 Таннберг, Т. Политика Москвы в республиках Балтии в послевоенные годы, 1944-1956: Исследование и документы. (История сталинизма.) ROSSPEN, Москва, 2010.

${ }^{212}$ Behind the iron curtain: Soviet Estonia in the era of the Cold War. Ed. by T. Tannberg. (Tartu historical studies, 5.) Peter Lang, Frankfurt am Main, 2015.

${ }^{213}$ Niitsoo, V. Vastupanu 1955-1985. Tartu Ülikooli Kirjastus, Tartu, 1997; Dissidentlik liikumine Eestis aastatel 1972-1987: Dokumentide kogumik. Koost A. Pesti. (Ad fontes, 17.) Rahvusarhiiv, Tallinn, 2009.

${ }^{214}$ Pihlau, J. Eesti demokraatlik põrandaalune ja kontaktid Läänega 1970-1985. I-VI. - Tuna, 2004, 2 - 2005, 3 .

${ }^{215}$ Vooglaid, Ü. Sotsioloogialabor (1966-1975). - Tartu Ülikooli ajaloo küsimusi, 1998, 30, 79-83; Pede, S. TRÜ sotsioloogia laboratooriumi sulgemise poliitilistest tagamaadest. - Tartu Ülikooli ajaloo küsimusi, 2001, 31, 111-129.

${ }^{216}$ Vako, E. „Meie aeg lööb auku müüri“: 1968. aasta üliõpilaspäevad Tartus ja Tallinnas. - Akadeemia, 2008, 2, 411-467; Alatalu, T. Eesti kommunistliku partei lõpu lugu koos julgete komnoorte meenutamisega. - Akadeemia, 2010, 1, 37-81. 
Kommunistliku partei tegevust Eesti valitsemisel on uurinud ja selle uurimist juhendanud Tõnu Tannberg. Avaldatud on ENSV kõrgeima kohaliku võimuasutuse, Eestimaa Kommunistliku Partei Keskkomitee büroo istungitel poole sajandi jooksul arutatud küsimuste loetelu. ${ }^{217}$ Mitte päris žanripuhta ajaloouurimusena väärib nimetamist ka Kaljo-Olev Veskimäe teos Eesti NSV valitsemisest kuni 1956. aastani. ${ }^{218}$ 2014. aastal kaitses Olev Liivik doktoritöö Eesti NSV valitsuse koosseisust ja isikkoosseisust Stalini ajal. Tema hiljem raamatuna ilmunud magistritöö käsitles EKP keskkomitee aparaati samal ajajärgul. ${ }^{219}$ Aastatel 1944-1947 valitseti annekteeritud Balti riike Üleliidulise Kommunistliku (bolševike) Partei Keskkomitee vastavate büroode vahendusel; Eesti büroo tegemisi uuris Tõnu Tannberg. ${ }^{220}$ Laiema üle-idaeuroopalise vaatena kuuluvad selle teema juurde ka Kaarel Piirimäe kaks artiklit. ${ }^{221}$ Eesti NSV välisasjade rahvakomissariaadist (välisministeeriumist) sõja lõpuaastal ja sõjajärgsetel aastatel ning Hans Kruusi rollist välisministrina on kirjutanud samuti Tõnu Tannberg. ${ }^{222}$ Võimu ja vaimu vahekorda Nõukogude okupatsiooni algusest kuni Stalini surmani on käsitlenud Olaf Kuuli. ${ }^{223}$

Nomenklatuurikorraldusest ehk avalike ametikohtade täitmise süsteemist kommunistliku partei vastava taseme komitee või büroo mitteavalike otsuste alusel on mitu uurimust, sh Mariliis Hämäläise magistritöö. ${ }^{224}$ Nomenklatuurile pühendatud Ajaloolise Ajakirja erinumbris analüüsiti süsteemi toimimist sõjajärgsel ajal Eesti NSV valitsuses ja julgeolekuorganeis. ${ }^{225}$

${ }^{217}$ EKP KK büroo istungite regestid. I kd (1940-1954), II kd (1954-1971), III kd (1971-1991). Eesti Ajalooarhiiv, Koost T. Tannberg. Tartu, 2006, 2011, 2011. Vt ka Enn Tarveli juhendamisel koostatud teatmikke „Eestimaa Kommunistliku Partei Keskkomitee organisatsiooniline struktuur“ ja „Partei-algorganisatsioon“.

${ }^{218}$ Veskimägi, K.-O. Kuidas valitseti Eesti NSV-d: Eestimaa Kommunistliku Partei Keskkomitee büroo 162 etteastumist 1944-1956 vahemängude ja sissejuhatusega. Varrak, Tallinn, 2005.

${ }^{219}$ Liivik, O. Eesti NSV Ministrite Nõukogu institutsionaalne areng ja kaadrid 1940-1953. (Dissertationes historiae Universitatis Tartuensis, 34.) Tartu Ülikooli Kirjastus, Tartu, 2014; Liivik, O. Eestimaa Kommunistliku Partei Keskkomitee aparaat 1945-1953. Tartu Ülikooli Kirjastus. Tartu, 1953.

${ }^{220}$ Tannberg, T. Moskva institutsionaalsed ja nomenklatuursed kontrollimehhanismid Eesti NSVs sõjajärgsetel aastatel. - Eesti NSV aastatel 1940-1953, 225-272; Tannberg, T. „Selle büroo ülesandeks on...": ÜK(b)P Keskkomitee Eesti büroo osas Eesti NSV sovetiseerimisel aastail 19441947. - Nõukogude Eesti külma sõja ajal, 11-30.

${ }^{221}$ Piirimäe, K. Nõukogude Liidu poliitika Ida-Euroopas 1944-1949. - Eesti NSV aastatel 19401953, 153-183; Piirimäe, K. 1944. aasta ,autonoomiaseadused“. Liiduvabariigid Kremli välispoliitikas liitlastevaheliste suhete kontekstis. - Eesti ajaloost nõukogude võimu perioodil, 13-45.

222 Tannberg, T. „Kui Tallinna hakkab saabuma mitmesuguseid alaliselt siin resideeruvaid diplomaate ...“: Dokumente Eesti NSV Välisministeeriumi algusaegadest 1944-1948. - Tuna, 2009, 4, 109-114; Tannberg, T. Miks Hans Kruusist ei saanud Eesti NSV välisasjade rahvakomissar juba 1944. aasta kevadel? - Tuna, 2011, 3, 72-87.

${ }^{223}$ Kuuli, O. Stalini-aja võimukaader ja kultuurijuhid Eesti NSV-s (1940-1954). O. Kuuli, Tallinn, 2007.

${ }^{224}$ Hämäläinen, M. Eestimaa Kommunistliku Partei Keskkomitee nomenklatuur 1945-1953. Tartu Ülikooli Kirjastus, Tartu, 2011; vt ka Hämäläinen, M. Eestimaa Kommunistliku Partei Keskkomitee nomenklatuur 1945-1990: areng ja statistika. - Nomeklatuurisüsteem Eesti NSV-s, 357-386.

${ }^{225}$ Liivik, O. Nomenklatuurisüsteemi funktsioneerimisest aastatel 1944-1953 Eesti NSV valitsusliikmete näitel. - Nomeklatuurisüsteem Eesti NSV-s, 387-406; Saueauk, M. „Erikaader“: nomenklatuur ja julgeolekuorganid Eesti NSV-s 1940-1953. - Nomeklatuurisüsteem Eesti NSV-s, 407-440. 
Põllumajanduse ja maaelu ümberkorraldamine oli sõjajärgse sovetiseerimise tähtis osa. See seisnes ,ajalooliselt meie rahvuskultuuri ja tootmiskogemusi kandvate ning majanduslikku initsiatiivi ja iseseisvust võimaldavate talude“226 likvideerimises ja kolhooside moodustamises. Maapiirkondade sovetiseerimine kulmineerus 1949. aasta küüditamisega, mis lisaks oma loetletud eesmärkidele oli ka heidutusaktsioon kolhooside moodustamise kiirendamiseks. Paralleelselt ühtlustati Balti riikide halduskorraldus üleliidulise süsteemiga ja likvideeriti kohaliku omavalitsuse riismed. Viimasest kaitses oma doktoritöö Indrek Paavle. ${ }^{227}$ Teema käsitlemine jääks poolikuks David Feesti artikleid nimetamata, oma doktoritöö kaitses ta kollektiviseerimisest Eestis. ${ }^{228}$ Anu-Mai Kõll avaldas monograafia taluomanike survestamisest enne kollektiviseerimiskampaaniat ja selle ajal. ${ }^{229}$ Majandusajaloolane Martin Klesment on uurinud Eesti põllumajandustoodangut alates 1920. aastast kuni 20. sajandi lõpuni. ${ }^{230}$

Eesti NSV tööstuse ja majanduse ajalugu laiemalt ning ka statistikat on uurinud Olaf Mertelsmann. 2003. aastal koostas ta Balti riikide sovetiseerimisest kogumiku, milles on artikkel stalinlikust industrialiseerimisest. ${ }^{231}$ Tema Eestis ilmunud tekstidest väärivad märkimist artikkel sisserände põhjustest Ida-Virumaale, sovetiseerimise mõistest, üleminekust turumajanduselt käsumajandusele jt. ${ }^{232} \mathrm{Ta}$ on kirjutanud ka kaks raamatut sõjajärgse Eesti ajaloost. ${ }^{233}$ 1959.-1965. aasta rahvamajandusnõukogude perioodi Eesti majanduses on käsitlenud Maie Pihla-

${ }^{226}$ Eesti NSV taluseaduse preambul. 6.12.1989. - Riigi Teataja, https://www.riigiteataja.ee/akt/30680 (04.08.2020).

${ }^{227}$ Paavle, I. Kohaliku halduse sovetiseerimine Eestis 1940-1950. (Dissertationes historiae Universitatis Tartuensis, 19.) Tartu Ülikooli Kirjastus, Tartu, 2009. Vt ka Paavle, I. Vallapartorgid - režiimi esindajad Eesti külas 1940. aastate teisel poolel. - Õpetatud Eesti Seltsi aastaraamat 2008. ÕES, Tartu, 2009, 91-125.

${ }^{228}$ Feest, D. Zwangskollektivierung im Baltikum: Die Sowjetisierung des estnischen Dorfes 1944 1953. (Beiträge zur Geschichte Osteuropas, 40.) Böhlau, Köln, 2007; Feest, D. Põllumajanduslik tootmine talupoegadeta: Sovhooside ideaalpilt ja tegelikkus 1940. aastate Eestis. - Nomeklatuurisüsteem Eesti NSV-s, 441-458.

${ }^{229}$ Kõll, A.-M. The Village and the Class War: Anti-Kulak Campaign in Estonia. (Historical Studies in Eastern Europe and Eurasia.) CEU Press, Budapest, New York, 2013.

${ }^{230}$ Klesment, M. Estonian agricultural production data: An interpretation through comparision. - Acta Historica Tallinnensia, 2008, 12, 145-162.

${ }^{231}$ Mertelsmann, O. Was there a Stalinist industrialization in the Baltic republics? Estonia: An example. - The Sovietization of the Baltic states, 1940-1956. Ed. by O. Mertelsmann. Kleio, Tartu, 2003, 151-169.

${ }^{232}$ Mertelsmann, O. Ida-Virumaale sisserändamise põhjused pärast Teist maailmasõda. - Ajalooline Ajakiri, 2007, 1 (119), 51-74; Mertelsmann, O. „Sovetiseerimise“ mõiste; Turumajanduselt käsumajandusele. - Eesti NSV aastatel 1940-1953, 13-29; 419-492; Mertelsmann, O. Alatoitumuse tekitamine põllumajanduslikult rikkas piirkonnas: Stalinistlik toiduainetega varustamise poliitika 1940. aastate Eestis. - Ajalooline Ajakiri, 2010, 2 (132), 191-211; Mertelsmann, O. Keskmine oodatav eluiga stalinismiaegses Eestis. - Ajalooline Ajakiri, 2011, 1 (135), 105-110; Mertelsmann, O. Külma sõja algusaja majanduslikud ja sotsiaalsed tagajärjed Eesti NSV-s. - Nõukogude Eesti külma sõja ajal, 163-199 jt.

${ }^{233}$ Mertelsmann, O. Die Sowjetisierung Estlands und seiner Gesellschaft. (Tartu historische Studien, 1.) Dr. Kovač, Hamburg, 2012; Everyday life in Stalinist Estonia. (Tartu historical studies, 2.) Peter Lang, Frankfurt am Main, 2012. 
mägi. ${ }^{234}$ Ühiskond ja majandus ei toimi väljaspool rahvastikku ning selles mõttes on tähtsad ka demograafide uurimused, nt Martin Klesmenti väitekiri sündimusest 20. sajandi teisel poolel. ${ }^{235}$

EKP Keskkomitee VIII pleenum 1950. aasta märtsis oli sovetiseerimise lõppakord Eestis. „Vanglakommunistid“ ja , juunikommunistid“ sunniti oma töö teinud moorlastena loovutama ametikohad mujalt NSV Liidust Eestisse suunatud parteifunktsionääridele, kelle seas oli hulk nn liidueestlasi. EKP juht Nikolai Karotamm asendati Johannes Käbiniga, kes seejärel juhtis Eesti NSV-d rohkem kui veerand sajandit. „Puhastati“ ülikool ja kõrgkoolid, loomingulised liidud jm. Mitu vanglaja juunikommunisti vangistati ja saadeti Gulagi laagritesse. VIII pleenumi teema pälvis ajaloouurijate tähelepanu juba laulva revolutsiooni aastatel stalinismi üleliidulise hukkamõistmise raamistikus. Pärast arhiivide avamist publitseeriti seni salajased olnud pleenumi materjalid. ${ }^{236}$ Pleenumi eri aspektidest on mitu põhjalikku uurimust. ${ }^{237}$ Stalini lõpuaastate kampaaniad, võitlus „kodanlike natsionalistide“ ja kosmopoliitide vastu, peegeldati ka Eestisse ning mõlemad olid teemaks VIII pleenumil. ${ }^{238}$ Lavrenti Beria ümberkorraldused tema lühikesel võimuajal 1953. aastal ning nende peegeldused Eestis on olnud Tõnu Tannbergi üks uurimisteemasid. ${ }^{239}$

Tsensuuri ja raamatute hävitamise uurimise üks esimesi saavutusi oli raamatukoguteadlase Kaljo-Olev Veskimägi 1996. aastal ilmunud teos. ${ }^{240}$ Viimastel aastatel on tsensuurile ja propagandale NSV Liidus taas rohkem tähelepanu pööratud. Ajaloouurimine armastab paralleele kaasaega. Pärast „tõejärgse“ veebipropaganda efektiivsuse avastamise üleilmset ehmatust 21. sajandi teisel kümnendil leidsid kommunistlike parteide võimu all elanud idaeurooplased hulga paralleele oma lähi-

${ }^{234}$ Pihlamägi, M. Eesti NSV tööstuse areng seitseaastakul (1959-1965) rahvamajanduse nõukogu reformi taustal. - Acta Historica Tallinnensia, 2013, 19, 115-146; vt ka vastuväited: Mertelsmann, $\mathbf{O}$. Tagasi sotsialismi juurde - Eesti majanduse parim võimalus? - Ajalooline Ajakiri, 2014, 2/3 (148/149), 265-270.

${ }^{235}$ Klesment, M. Fertility development in Estonia during the second half of the XX century: The economic context and its implications. (Tallinna Ülikooli sotsiaalteaduste dissertatsioonid, 46.) Tallinna Ülikool, Tallinn, 2010.

${ }^{236}$ EK(b)P Keskkomitee VIII pleenumi stenogramm. I-XI. Koost M. Arold, J. Isotamm. - Akadeemia, 1998, 12 - 1999, 10

237 Tannberg, T. 1950. aasta märtsipleenumi eel- ja järellugu: „Eesti süüasi“ (1949-1952) Moskvast vaadatuna. - Tuna, 2001, 3, 120-125; Feest, D. Põlisrahvuste taaseelistamise poliitika Balti liiduvabariikides? Eestimaa Kommunistlik Partei pärast Teist maailmasõda. - Eesti NSV aastatel 1940 1953, 207-224; Liivik, O. Tagasivaade 1950. aasta märtsipleenumile: Kas venelased ja Venemaa eestlased saavutasid võidu ,juunikommunistide” ja „korpusemeeste” üle? - Tuna, 2010, 1, 55-69; Saueauk, M. „Eesti süüasi“ hilisstalinistlike parteipuhastuste taustal. - Nõukogude Eesti külma sõja ajal, 59-87.

${ }^{238}$ Liivik, O. Campaign against "bourgeois nationalism" and repressions in Estonia; Persecution of Jews in Estonia in the late 1940's and early 1950's. - Estonia since 1944, 113-129; 405-414.

${ }^{239}$ Vt nt Tannberg, T. After Stalin: The Kremlin's “new nationalities policy” and Estonia in 1953. War, revolution, and governance: The Baltic countries in the twentieth century. Ed. by L. Fleishman, A. Weiner. Academic Studies Press, Stanford, 2018, 207-239.

${ }^{240}$ Veskimägi, K.-O. Nõukogude unelaadne elu: Tsensuur Eesti NSV-s ja tema peremehed. K.-O. Veskimägi, Tallinn, 1996; vt ka Lotman, P. Hävitatud raamat ja eestlase identiteet. Tuna, 2000, 2, 95-103. 
mineviku „tõeministeeriumide“ praktikast. Ajaloolise Ajakirja propaganda ja tsensuuri erinumber keskendus peamiselt 1940. aastatele. ${ }^{241}$ Anu Raudsepa artikkel käsitles kodu- ja väliseestlaste kirjavahetust 1940. ja 1950. aastatel ning Anneli Saro kirjutas tsensuurist teatris. ${ }^{242}$ Kirjavahetuse ja tsensuuri teemaga seostub Meelis Saueaugu artikkel kirjavahetuse salajasest kontrollist - valdkond, mis oli peidus sovetliku salastamise kõige salajasemas nurgas. ${ }^{243}$ Epp Lauk ja Tiiu Kreegipuu uurisid ajakirjanduse, propaganda ja varjatud vastupanu vahekorda. Samal teemal on Kreegipuu doktoriväitekiri. ${ }^{244}$ Marek Miil on kirjutanud propagandast meedias ja parteiorganite võitlusest Soome televisiooni vaatamisega Tallinnas ja Põhja-Eestis. Sellest on ka tema doktoriväitekiri. ${ }^{245}$

Rahva meelsuse, tänapäeva mõistes suuresti avaliku arvamuse uurimisega tegelesid NSV Liidus julgeoleku- ja parteiorganid oma meetodeid kasutades. Nende materjalide põhjal on teemat uurinud Hiljar Tammela, Peeter Kaasik jt. ${ }^{246}$ Julgeolekuorganite nuhkidest ja pealekaebajatest sõjajärgsel ajal on kirjutanud Jaak Pihlau ja Tiit Noormets. ${ }^{247}$ Noormets on peamiselt ajakirjas Tuna avaldanud küm-

${ }^{241}$ Tannberg, T. „Tsensuuri töö on väga vastutusrikas“: Dokumentaalne pilguheit Eesti NSV Glavliti tegevusele aastatel 1941-1948. - Tsensuur ja propaganda Nõukogude Eestis, 337-353; Piirimäe, K. „Tugev Balti natsionalistlik keskus“ ning Nõukogude välispropaganda teel sõjast rahuaega ja külma sõtta. - Tsensuur ja propaganda Nõukogude Eestis, 305-336.

${ }^{242}$ Raudsepp, A. Erakirjad infoallikana Eesti ja Lääne vahel stalinismist sulani (1946-1959). - Tsensuur ja propaganda Nõukogude Eestis, 255-281; Saro, A. Nõukogude tsensuuri mehhanismid, strateegiad ja tabuteemad Eesti teatris. - Tsensuur ja propaganda Nõukogude Eestis, 283-304.

${ }^{243}$ Saueauk, M. „Salajane kontroll“: Sõnumisaladuse rikkumisest Nõukogude Liidus ja Eesti NSV-s. - Tuna, 2014, 2, 50-69.

${ }^{244}$ Lauk, E., Kreegipuu, T. Was it all pure propaganda? Journalistic Practices of "silent resistance" in Soviet Estonian journalism. - Acta Historica Tallinnensia, 2010, 15, 167-190; Kreegipuu, T. The ambivalent role of Estonian Press in Implementation of the Soviet Totalitarian Project. (Dissertationes de mediis et communicationibus Universitatis Tartuensis, 15.) Tartu University Press, Tartu, 2011.

${ }^{245}$ Miil, M. Mäng mäluga: 22. september 1944 Eesti NSV päevalehtedes ajavahemikul 1945-1989. - Ajalooline Ajakiri, 2011, 2 (136), 189-222; Miil, M. Eesti Televisiooni raskustest Soome TV „katmisel“: EKP võitlus „kodanliku“ televisiooni vastu. - Acta Historica Tallinnensia, 2012, 18, 108-141; Miil, M. Kommunistliku Partei propagandastrateegiad ja „kodanliku“ televisiooni neutraliseerimine Eesti NSV-s 1968-1988. - Ajalooline Ajakiri, 2013, 1 (143), 79-110; Miil, M. Nõukogude propagandasüsteemi toimimine ajakirjanduse argipraktikate kaudu. (Dissertationes de mediis et communicationibus Universitatis Tartuensis, 23.) Tartu Ülikooli Kirjastus, Tartu, 2014.

${ }^{246}$ Tammela, I. Estonian's views on events abroad and in the Soviet Union 1944-1950. - Estonia since 1944, 151-162; Tammela, I. Waiting for the white ship: The expectation of World War III among the population of Soviet Estonia (1945-56). - The Baltic states under Stalinist rule, 189208; Kaasik, P. Kuulujuttudest Nõukogude Eestis partei ja julgeoleku meelsusaruannete põhjal 1944-1953. - Ajalooline Ajakiri, 1 (163), 2018, 67-88; Kaasik, P. „Meeleolu on positiivne, kuid ...": avalikust arvamusest Nõukogude Eestis partei ja julgeoleku meelsusaruannete põhjal. I-II. - Tuna, 2014, 4, 57-73; 2015, 1, 51-70.

${ }^{247}$ Pihlau, J. Aleksander Viidiku varjatud elu: Vabadussõjalasest NKVD tippagendiks. - Akadeemia, 2002, 4, 721-735; Noormets, T. Agendid, nuhid, pealekaebajad. - Tuna, 2012, 4, 89-98; Noormets, T. „Klassivaenlase poolt on organiseeritud rida mitmesuguseid nõukogude vastaseid väljendusi ...": Eestimaa Kommunistliku (bolševike) Partei maakonnakomiteede informatsioonid keskkomiteele rahva meeleolust 1946-1949. - Tuna, 2016, 2, 111-125. 
neid uurimusi ja lühiuurimusi, millest suur osa käsitleb sõjajärgset ja hilisemat aega. ${ }^{248}$ Suurt hulka üksikküsimusi on uurinud ka Valdur Ohmann. ${ }^{249}$

Nõukogude-aegset haridussüsteemi, õieti selle allutatust kommunistlikule ideoloogiale, aga ka õpetajaskonna-poolset ideoloogilise surve trotsimist on uurinud Anu Raudsepp, Mare Oja, Eli Pilve jt. Anu Raudsepa ja Mare Oja doktoriväitekiri on ajaloo õpetamisest, ${ }^{250}$ Eli Pilve artiklid aga kommunistlikust ideoloogiast õpikutes ja õppekavades ning takistustest, mis seati ,antisovetlike elementide“ laste haridusteele. ${ }^{251}$

Okupeeritud Eestist põgenemist ja ebaõnnestunud põgenemiskatseid uuris peamiselt julgeoleku uurimistoimikute põhja Jaak Pihlau. ${ }^{252}$ Isikuvabaduste olukorra uurimist laiemas vaates alustas Indrek Paavle. Tema artiklid on passisüsteemist, liikumispiirangutest ja töökohustusest. ${ }^{253}$ Õppevahendiks või juhendmaterjaliks Nõukogude aja uurimisel on kasutatav tema allikauurimus Nõukogude võimuasutuste dokumentidest. $^{254}$

Nõukogude armee eesti rahvusväeosi aastatel 1945-1956 on uurinud Peeter Kaasik $^{255}$ ja Eesti NSV elanike sundajateenistust Nõukogude armees alates Teise

${ }^{248}$ Noormets, T. „Rahvusvahelise reaktsiooni poolt Olümpiamängude ümber sepitsetud sehkendamine ei andnud dividende ...": KGB-teaduslik artikkel Tallinna Olümpiaregatist „Kõrgkooli töödes“. Tuna, 2008, 3, 73-79; ,Kotipoisid“ sõjajärgses Eestis. - Tuna, 2015, 4, 74-80.

${ }^{249}$ Vt nt Ohmann, V. Gustav Naani kaebekiri EKP Keskkomiteele. - Tuna, 2005, 3, 96-104; Ohmann, V. Perekond Raus ENSV kaitseliinil. - Tuna, 2015, 3, 98-113.

${ }^{250}$ Raudsepp, A. Ajaloo õpetamise korraldus Eesti NSV eesti õppekeelega üldhariduskoolides 1944 1985. (Dissertationes historiae Universitatis Tartuensis, 10.) Tartu Ülikool, Tartu, 2005. Vt ka Raudsepp, A. Keskkooliõpetajate koolitamine sõjajärgses Tartu Riiklikus Ülikoolis. - Tartu Ülikooli ajaloo küsimusi, 2016, 44, 121-140; Raudsepp, A., Veski, K. Vaenlase ja kangelase kuvandid sõjajärgse stalinismi aegsetes eestikeelsetes originaalõpikutes. - Nõukogude Eesti külma sõja ajal, 200-217. Oja, M. Muutused üldhariduskooli ajalooõpetuses alates 1987. aastast - nõukogulikust tänapäevaseks. (Tallinna Ülikooli humanitaarteaduste dissertatsioonid, 27.) Võrguteavik, Tallinna Ülikool, 2016.

${ }^{251}$ Pilve, E. „Aga vene ajal pidi igas õppetunnis siduma õppematerjali poliitikaga“: Ideoloogiline kasvatus nõukogude koolitunnis hilisstalinistlikus Eesti NSVs. - Tuna, 2010, 4, 54-71; Pilve, E. Nõukogude noore kasvatamisest paberil ja päriselt: Ideoloogiline ajupesu nõukogude kooli(tunni)s 1953-1991. - Tuna, 2013, 3, 82-100; Pilve, E. „Kurnajate“ ja „rahvavaenlaste“ perekonnaliikmed Nõukogude võimu kammitsais. - Tuna, 2017, 1, 58-73.

${ }^{252}$ Pihlau, J. Lehekülgi Eesti lähiajaloost: Merepõgenemised okupeeritud Eestist. - Tuna, 2001, 2, 69-81; Pihlau, J. Lehekülgi Eesti lähiajaloost: Maapõgenemised okupeeritud Eestist. - Tuna, 2001, 3, 37-71; Pihlau, J. Eestlaste põgenemised Läände: ärahüppajad. I-III. - Tuna, 2003, 1-3.

${ }^{253}$ Paavle, I. Ebaühtlane ühtne süsteem I: Sovetliku passisüsteemi kujunemine, regulatsioon ja rakendamine Eesti NSV-s. - Tuna, 2010, 4, 37-53; Paavle, I. Ebaühtlane ühtne süsteem II: Sovetliku passisüsteemi rakendamine Eesti NSV-s. - Tuna, 2011, 2, 43-67; Paavle, I. Kuidas ära hoida „nõukogudevastaste elementide karistamatu lahkumine“" Eesti NSV territooriumilt? Piirirežiimi regulatsioon ja kontroll Eesti NSV-s. - Tuna, 2012, 3, 61-91; Paavle, I. „Kes tööd ei tee, ei pea ka sööma!" Ühe lootusetu võitluse lugu: Nõukogude töökohustus ja parasiitide vaenamine Eesti NSV-s. I-II. - Tuna, 2015, 3, 76-89; 4, 51-66.

254 Paavle, I. Seadusest käskkirjani: NSV Liidu õigusaktide klassifikatsioonist ja kasutamisest ajaloouurimises. - Eesti ajaloost 19.-20. sajandil: Uurimusi historiograafiast, allikaõpetusest ja institutsioonidest. (Eesti Ajalooarhiivi toimetised, 19 (26).) Eesti Ajalooarhiiv, Tartu, 528-547.

${ }^{255}$ Kaasik, P. Eesti rahvusväeosade formeerimisest, 136-144. 
maailmasõja lõpust Kristjan Luts. Sel teemal kaitses ta ka oma doktoriväitekirja. Lisaks on ta kirjutanud artikleid külma sõja ajal USA ja teiste lääneriikide armeedes teeninud eestlastest. ${ }^{256}$

Suhtlemine kodu- ja väliseestlaste vahel on mahukas teemavaldkond. Sellel on seosed välispoliitika, külma sõja vastaspoolte vastastikuse luurega, sh teadusja tööstusspionaaži ja mõjutustegevusega. Siia kuulub ka Väliseestlastega Kultuurisidemete Arendamise Eesti Ühingu, ajalehe Kodumaa, Balti Instituudi jt organisatsioonide tegevuse ajalugu. Kõigil neil teemadel on palju kirjutanud eesti pagulased. Nimetan siinkohal ainult kaks uuema aja uurimust nooremate Eestis töötavate uurijate sulest: Triin Tark on uurinud NSV Liidu kultuuridiplomaatia suhtumist kodu- ja väliseestlaste suhtlemisse, Ivo Juurvee aga Nõukogude propaganda välisauditooriumile suunatud mõjutustegevust spetsiaalselt selleks kirjastatud raamatute ja perioodika abil. ${ }^{257}$ Üle raudse eesriide liikumist turismi näitel on uurinud Oliver Pagel. ${ }^{258}$

\section{EESTI ISESEISVUSE TAASTAMINE JA 20. SAJANDI LÕPP}

Mida lähemale tänapäevale, seda rohkem on lähiminevik pigem poliitilise debati kulumaterjal kui akadeemilise ajaloouurimise teema. Mõõdetakse ühe või teise isiku või erakonna või ühiskondliku liikumise osa saavutustes ja süüd nurjumistes ning defineeritakse omad ja teised. Paljud 1980. ja 1990. aastate vahetuse poliitilised liidrid ja poliitilised aktivistid, aga ka esimesed diplomaadid ja ohvitserid olid ajaloolased või siis Tartu ülikooli ajalooteaduskonna (-osakonna) lõpetanud. Seda sellepärast, et poliitika- ja riigiteadused ning nende valdkondade kõrgharidus nüüdisaegses tähenduses oli Nõukogude Liidus olnud ainupartei enam-vähem absoluutse kontrolli all. Niisiis pani NSV Liidu kokkuvarisemine märgi külge ka neid erialasid õppinutele ja nendes valdkondades Nõukogude ajal tegutsenutele. Praegu on lugeja käsutuses mitme iseseisvuse taastamise aegse juhtiva ajaloolasest poliitiku ajalookirjutamise ambitsiooniga raamatud, mida selle aja käsitlemisel kõrvale jätta

${ }^{256}$ Luts, K. Eestlased Nõukogude armees 1968-1991. - Eesti ajaloost nõukogude võimu perioodil, 253-280; Luts, K. Eestlastest ohvitserid NSV Liidu relvajõududes pärast Teist maailmasõda: Esmane uurimiskatse. - Uurimusi historiograafiast, allikaõpetusest ja institutsioonidest, 298-324; Luts, K. Ülevaade eestlastest Ameerika Ühendriikide relvajõududes pärast Teist maailmasõda. Väeteenistusest Eestis ja eestlastest väeteenistuses, 274-307; Luts, K. Eestlastest ajateenijad ja ohvitserid Nõukogude Liidu relvajõududes 1956-1991. (Dissertationes historiae Universitatis Tartuensis, 41.) Tartu Ülikooli Kirjastus, Tartu, 2017.

${ }^{257}$ Tark, T. Kodu- ja väliseestlaste vahelise kultuurisuhtulse institutsionaalne raamistik Nõukogude Liidu kultuuridiplomaatia kontekstis. - Ajalooline Ajakiri, 2017, 4 (162), 445-474; Juurvee, I. Vähetuntud lugu pehme jõu kasutamisest külmas sõjas. - Akadeemia, 2013, 9, 1694-1702; Juurvee, I. Idabloki eriteenistused Külma sõja ajaloorindel Andrus Roolahe ja Julius Maderi näitel. Eesti ajaloost nõukogude võimu perioodil, 47-76.

${ }^{258}$ Pagel, O. Finnish tourists in Soviet Estonia: Security considerations. - Journal of Baltic Studies, 2019, 50, 3, 1-17; Pagel, O. Finnische Touristen entdecken das sowjetische Tallinn. - Forschungen zur baltischen Geschichte, 2014, 9, 215-234. 
ei saa ega jäetagi. ${ }^{259}$ Lisaks on avaldatud artiklikogumikke nii erakondade 260 kui ka näiteks välisministeeriumi ajaloost. ${ }^{261}$ 2007. aastal ilmus kogumik 1987. aasta augustis peetud Hirvepargi koosoleku 20. aastapäevaks, tähistamaks iseseisvusliikumise esimese massilise rahvaürituse tähtpäeva. ${ }^{262}$

Mati Graf on iseseisvuse taastamisele pühendanud kaks mahukat monograafiat. ${ }^{263}$ Kaarel Piirimäe ja Maria Mälksoo koostasid Ajaloolise Ajakirja erinumbri, mis võrdleb Balti riikide loomist pärast Esimest maailmasõda ja iseseisvuse taastamist pärast külma sõja lõppu. ${ }^{264}$ Balti riikide iseseisvuse taastamisele on pühendatud Kaarel Piirimäe ja Olaf Mertelsmanni koostatud artiklikogumik. ${ }^{265}$ Teoreetilisemast vaatepunktist on Eesti iseseisvuse taastamise käsitlemist uurinud Rein Ruutsoo ja Peeter Selg. ${ }^{266}$ Laulvale revolutsioonile, iseseisvuse taastamisele ja taastatud riigi esimestele aastatele on pühendatud kümneid eri kvaliteediga artiklikogumikke, mis uurivad külma sõja lõpuga seotud sündmusi nii Eestis kui ka laiemas vaates, ${ }^{267}$ ja küllap sadu artikleid eesti ja välismaa akadeemilistes ja kultuuriväljaannetes, millest tähtsamate väljaselitamine ootab, et aeg astuks neist sündmustest mõne sammu kaugemale.

${ }^{259}$ Oplatka, A. Lennart Meri - Eestile elatud elu: Kahekõne presidendiga. 3. tr. Hea Lugu, Tallinn, 2017; Laar, M. Pööre: Mälestusi I. Read, Tallinn, 2015; Savisaar, E. Peaminister: Eesti lähiajalugu 1990-1992. Kleio, Tartu, 2004; vt ka Laar, M., Ott, U., Endre, S. Teine Eesti: Eesti iseseisvuse taassünd 1986-1991. SE\&JS, Tallinn, 2000.

${ }^{260}$ Niitsoo, V. Müürimurdjad: MRP-AEG ja ERSP lugu. Ortwil, Tallinn, 2002; Eestimaa Rahvarinne 30: Artiklite kogumik I: Rahvarinde ajaloo I konverentsiks 30. septembril 2018 Rahvusraamatukogus. Koost K. Gerndorf. Rahvarinde Pärimusselts, Rahvarinde muuseum, Tallinn, 2018.

${ }^{261}$ Teine tulemine: Taasiseseisvunud Eesti välisesindused. Koost E. Eek-Pajuste. Välisministeerium, Tallinn, 2003; Teine tulemine II: Välisministeeriumi taasloomise lugu. Koost E. Eek-Pajuste. Välisministeerium, Tallinn, 2008.

${ }^{262}$ Hirvepark 1987: 20 aastat kodanikualgatusest, mis muutis Eesti lähiajalugu. Peatoim T. Tannberg. Kultuuriselts Hirvepark, Tallinn, 2007.

${ }^{263}$ Graf, M. Kalevipoja kojutulek: 1978. aasta poliitilisest pööripäevast 1988. aasta suveräänsusdeklaratsioonini. Argo, Tallinn, 2008; Graf, M. Impeeriumi lõpp ja Eesti taasiseseisvumine 1988 1991. Argo, Tallinn, 2012.

${ }^{264}$ Baltic independence in the twentieth century (Ajalooline Ajakiri, 2016, 3/4 (157/158).) Vt sissejuhatav artikkel: Piirimäe K., Mälksoo, M. Western policies and the impact of tradition at critical junctures: The Baltic states after the First World War and the Cold War. - Samas, 337-345.

${ }^{265}$ The Baltic States and the end of the Cold War. Ed. by K. Piirimäe, O. Mertelsmann. (Tartu historical studies, 6.) Peter Lang, Berlin, 2018.

${ }^{266}$ Ruutsoo R., Selg, P. Teleoloogiline ajaloonarratiiv kui poliitilise antagonismi konstrueerimise strateegia Eesti taasiseseisvumise käsitluste näitel. - Acta Semiotica Estica, 2012, 9, 109-143. Vt ka Ruutsoo, R. Civil society and nation building in Estonia and the Baltic states: Impact of traditions on mobilization and transition 1986-2000: Historical and sociological study. (Acta Universitatis Lapponiensis, 49). University of Lappland, Rovaniemi, 2002.

${ }^{267}$ Eesti poliitika ja valitsemine 1991-2011. Koost R. Vetik. (Acta Universitatis Tallinnensis. Socialia.) Tallinna Ülikooli Kirjastus, Tallinn, 2012. Vt ka: Inventing the national defence: Eastern Europe between the fall of the Berlin wall and accession to NATO. (Eesti sõjaajaloo aastaraamat, 4 (10).) Eesti sõjamuuseum - kindral Laidoneri muuseum, Tallinna Ülikooli Kirjastus, Tallinn, 2015. 


\section{KOKKUVÕTTEKS}

2010. aastal, kümmekond aastat pärast S-Keskuse korraldatud arutelusid, millele eespool on viidatud, korraldasid Hiljar Tammela ja Olev Liivik ajaloolaste seas küsitluse selle kohta, mis on lähiajaloos veel uurimata. Lähiajalooks defineerisid nad mitte „lühikese 20. sajandi“ Esimese maailmasõja lõpust külma sõja lõpuni, vaid kogu sajandi: „Soovimata siinkohal astuda omaette diskussiooni mõiste „lähiajalugu“ süvatasandite ja piiride üle, oleme käesolevas kirjatöös mõistnud „lähiajalugu“ tähenduses „20. sajandi ajalugu“ ehk siis tinglikult ajavahemikku 1. jaanuarist 1901 kuni 31. detsembrini 2000.“268

Selle lähiajaloo kohta Eestis kirjutatu on olnud ka siinse artikli uurimisobjekt. Kas möödunud sajandi Eesti ajaloo uurimine on algusjärgus, poole peal või lõpusirgel, on valesti püstitatud küsimus. Iga põlvkond peab tegelema juba kirjutatud ajaloo ümberkirjutamisega ning lõplikku 20. sajandi ajalugu ei kirjutata kunagi. Eesti 20. sajandi ajaloos on hulk teemasid, mida on vähe uuritud või mis vajavad värskendamist, nagu eespool ka osutatud. Loodetavasti peavad seda silmas nii uurimisprojektide rahastuse üle otsustajad kui ka ajaloolased ise. Eelkäijate jälgede suuremaks astumine ja nendega väitlemine on ahvatlev ja vajalikki, kuid päris uus võib niiviisi sündimata jääda.

\section{ESTONIAN CONTEMPORARY HISTORY IN THE TWENTY-FIRST CENTURY}

\section{Toomas HIIO}

The main objective of the article is to give an overview of the research into Estonian contemporary, i.e. twentieth-century, history over the last twenty years. The article is focussed mainly, but not exclusively, on the work of historians who are active at Estonian universities and other research institutions and on their monographs and articles published mainly in Estonia. This article is deliberately limited to the general branch of historical research. Special branches like archaeology, ethnology and art history are left outside of the scope of this paper.

During the last twenty years historical research has been conducted primarily at two universities, the University of Tartu and Tallinn University, in addition to which a few research centres have been created under different initiatives. These work usually in the form of NGOs or foundations, indirectly financed from the state budget. First, there is the Estonian Repressed Persons Records Bureau, at the national-level Estonian Memento Union of former Soviet political prisoners and deportees. Secondly, in 1992/1993 the Estonian parliament founded the Estonian State Commission on the Examination of the Policies of Repression. The commission finished its work in 2005 with publishing of the White Book on Estonian losses due

${ }^{268}$ Tammela, H., Liivik, O. Kas Eesti lähiajaloos on endiselt „,valgeid laike”? - Tuna, 2010, 4, 129 135 (siinne joonealuses $1 \mathrm{k} 129$ ). 
to the occupations, 1940-1991. Both institutions had explicit tasks meaning that broader academic research was a side product of their activities. Thirdly, in between 1996 and 1999 NGO S-Keskus (S-Centre) was founded for research into the Soviet period in Estonia. Fourthly, the Estonian International Commission for the Investigation of Crimes Against Humanity was convened in 1998 by then President of Estonia Lennart Meri in order to research crimes against humanity during and after World War II in Estonia. The commission's research team worked in the form of a foundation. On this basis later President Toomas Hendrik Ilves convened the Estonian Institute of Historical Memory in 2008 to conduct research into the violation of human rights in Estonia during the post-war period. And last but not least, historical research, particularly into the twentieth century, has been actively conducted at the Estonian State Archives (today part of Estonian National Archives).

The Estonian history of the twentieth century is usually divided into periods such as the revolution of 1905, World War I, the birth of the Republic of Estonia, the War of Independence, the Republic of Estonia during interwar period including the years 1934-1940 of authoritarian rule, the loss of independence in 1939-1940, the Soviet occupation of 1940-1941, the German occupation of 1941-1944, World War II 1939-1945, the second Soviet occupation 1944-1991, the singing revolution and the restoration of independence in 1987/1988-1991, and Estonia since 1991. The research into these periods is briefly addressed separately in the article. The periods of loss of independence and of the Second World War have probably received the greatest attention from Estonian historians, followed by topics like political repressions against Estonian citizens and residents, and armed as well as unarmed resistance. In connection with 100th anniversaries of the Republic of Estonia, the creation of Estonian statehood, the Estonian War of Independence and the First World War are well covered by research. The authoritarian rule of President Päts, his takeover in 1934, the radical right movement of soldiers of the War of Independence and the role of President Päts and the members of his government have been debated among historians, as well as within society in general since the 1990s. Several tens of $\mathrm{PhD}$ theses have been defended on the history of the 20th century over the last couple of decades, to say nothing about everyday academic research. Despite this many periods and themes still await exploration in the future - the pre-First World War history, many aspects of the history of interwar Estonia and the history of government and everyday life of the Soviet period from Stalin's death to the collapse of the Soviet Union, to mention just a few. 